DOE/RL-96-70

Rev. 0

\title{
300-FF-1 Remedial Design Report/Remedial Action Work Plan
}


TRADEMARK DISCLAIMER

Reference herein to any specific commercial product, process, or service by trade name, trademark, manufacturer, or otherwise, does not necessarily constitute or imply its endorsement, recommendation, or favoring by the United States Government or any agency thereof or its contractors or subcontractors.

This report has been reproduced from the best available copy. Available in paper copy and microfiche.

Available to the U.S. Department of Energy and its contractors from

Office of Scientific and Technical Information

P.O. Box 62

Oak Ridge, TN 37831

(615) $576-8401$

Available to the public from the U.S. Department of Commerce National Technical Information Service

5285 Port Royal Road

Springfield, VA 22161

(703) $487-4650$

Printed in the United States of America

DISCLM-5.CHP (8-91) 


\section{0-FF-1 Remedial Design Report/ Remedial Action Work Plan}

\section{Date Published \\ February 1997}

\begin{abstract}
DISCLAIMER
This report was prepared as an account of work sponsored by an agency of the United States Government. Neither the United States Government nor any agency thereof, nor any of their employees, makes any warranty, express or implied, or assumes any legal liability or responsibility for the accuracy, completeness, or usefulness of any information, apparatus, product, or process disciosed, or represents that its use would not infringe privately owned rights. Reference herein to any specific commercial product, process, or service by trade name, trademark, manufacturer, or otherwise does not necessarily constitute or imply its endorsement, recommendation, or favoring by the United States Government or any agency thereof. The views and opinions of authors expressed herein do not necessarily state or reflect those of the United States Government or any agency thereof.
\end{abstract}

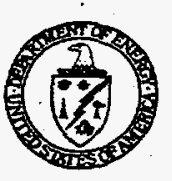

\section{United States} Department of Energy P.O. Box 550

Richland, Washington 99352 


\section{DISCLAMMER}

Portions of this document may be illegible in electronic image products. Images are produced from the best available original document. 
DOE/RL-96-70

Rev. 0

\section{CONTENTS}

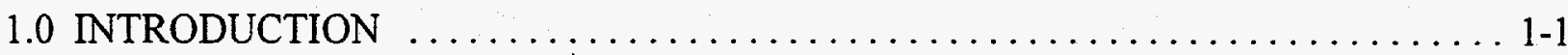

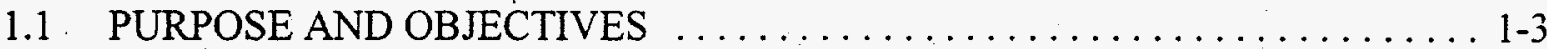

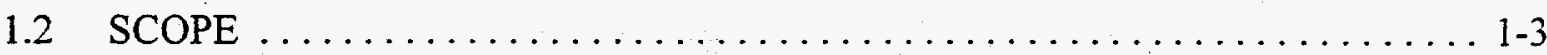

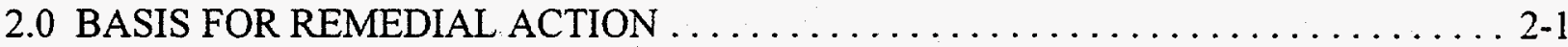

2.1 RECORD OF DECISION SUMMARY AND DECISION DEFINITION ...... 2-1

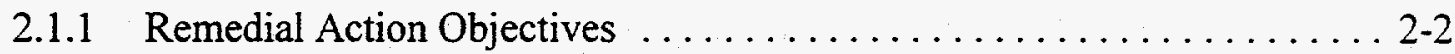

2.1.2 Remedial Action Goals ........................... 2-3

2.1.3 Application of Remedial Action Goals .................. 2-6

2.1.4 Contaminant-Specific Concentrations in Soil ............... 2-6

2.1.5 Applicable or Relevant and Appropriate Requirements ........... 2-8

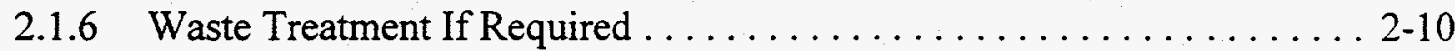

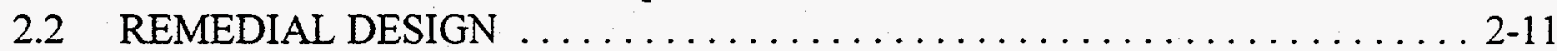

2.2.1 General Remediation Procedures .................... 2-14

2.2.2 General Design Elements Common to All Waste Sites ........... 2-17

2.2.3 Design Elements Specific to Individual Waste Sites ........... 2-23

3.0 REMEDIAL ACTION APPROACH AND MANAGEMENT $\ldots \ldots \ldots \ldots \ldots \ldots \ldots$ 3-1

3.1 REMEDIAL ACTION PROCESS DESCRIPTION $\ldots \ldots \ldots \ldots \ldots \ldots \ldots$.

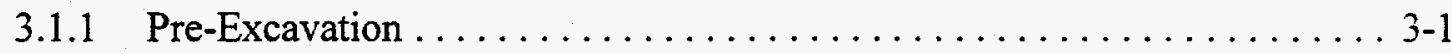

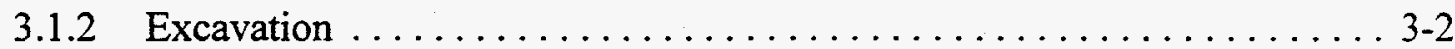

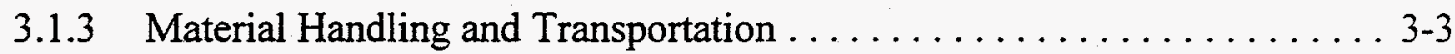

3.1.4 Soil/Debris Characterization and Analysis $\ldots \ldots \ldots \ldots \ldots \ldots \ldots .3-3$

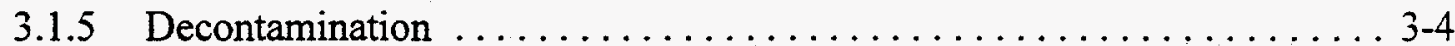

3.1.6 Waste Profile Station . . . . . . . . . . . . . . . . . . . . . . . . 3-4

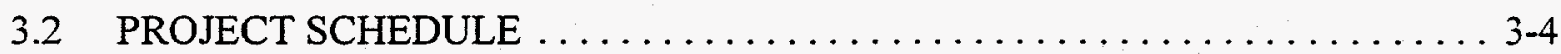

3.2.1 Remedial Design/Remedial Action Work Plan $\ldots \ldots \ldots \ldots \ldots \ldots \ldots . .5$

3.2 .2 Procurement .................................. 3-5

3.2.3 Remedial Actions . . . . . . . . . . . . . . . . . . .

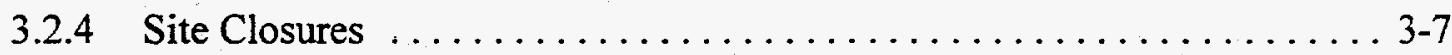

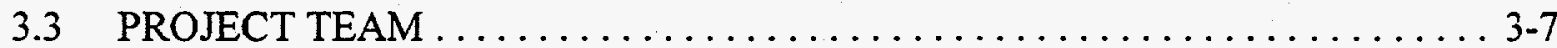

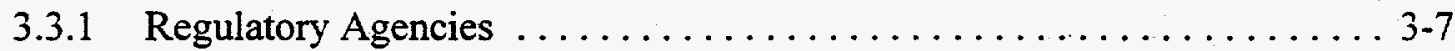

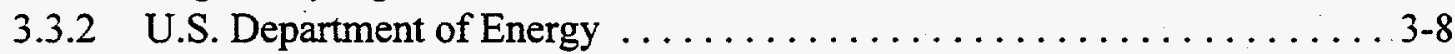

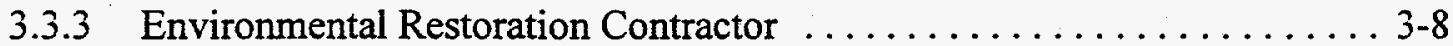

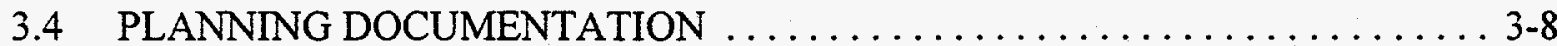

3.4.1 Field Procedures/Permits ........................... 3-8

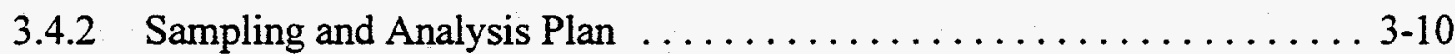

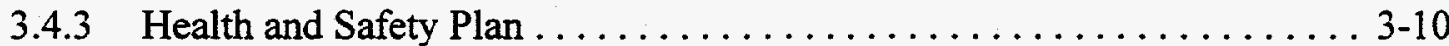

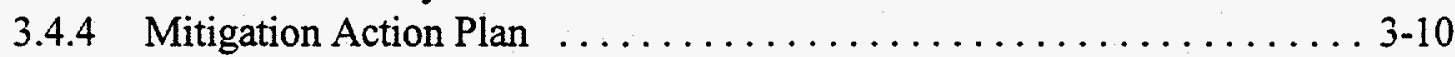

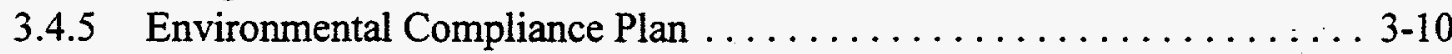

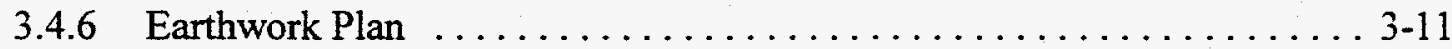


DOE/RL-96-70

Rev. 0

\section{CONTENTS (Continued)}

3.4.7 Excavated Material Handling Plan $\ldots \ldots \ldots \ldots \ldots \ldots \ldots \ldots . . \ldots \ldots . . \ldots \ldots$

3.4.8 Public Involvement Plan ......................... $3-11$

3.5 REMEDIAL ACTION CHANGE MANAGEMENT $\ldots \ldots \ldots \ldots \ldots \ldots \ldots . . \ldots \ldots$

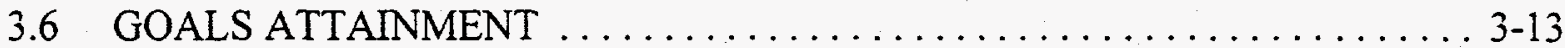

3.6.1 Identify Units for Cleanup Verification ................. $3-13$

3.6.2 Identify the Appropriate Remedial Action Goal(s) . . . . . . . . . 3-13

3.6.3 Define Decision Rules ............................ 3-14

3.6.4 Calculate Summary Statistics $\ldots \ldots \ldots \ldots \ldots \ldots \ldots \ldots \ldots \ldots \ldots \ldots \ldots \ldots \ldots .14$

3.6.5 Verify Attainment of Proposed Radionuclide Soil Cleanup Standards . . 3-14

3.6.6 Verify Attainment of MTCA Cleanup Standards .............. 3-15

3.6.7 Verify Attainment of Groundwater and Columbia River Remedial Action Goals .............................. $3-15$

3.7 CERCLA CLOSEOUT DOCUMENTATION $\ldots \ldots \ldots \ldots \ldots \ldots \ldots \ldots \ldots \ldots \ldots \ldots$

3.8 RCRA CLOSURE OF THE PROCESS TRENCHES $\ldots \ldots \ldots \ldots \ldots \ldots \ldots . \ldots \ldots$

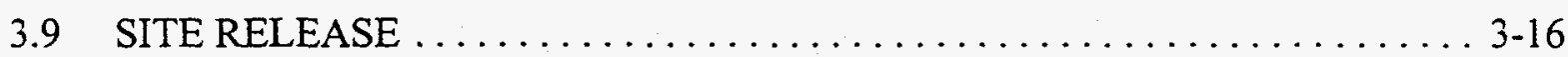

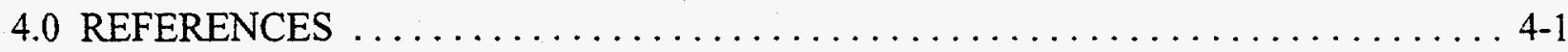

\section{APPENDICES:}

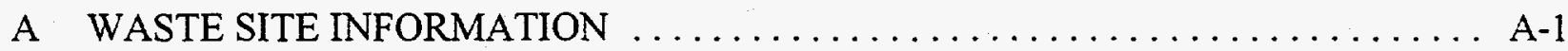

B SUMMARY OF RESIDUAL RADIOACTIVITY METHODOLOGY $\ldots \ldots \ldots \ldots$.

C SAMPLING AND ANALYSIS PLAN $\ldots \ldots \ldots \ldots \ldots \ldots \ldots \ldots \ldots \ldots \ldots \ldots \ldots \ldots \ldots \ldots \ldots$

D 300 AREA ENVIRONMENTAL MANAGEMENT PUBLIC

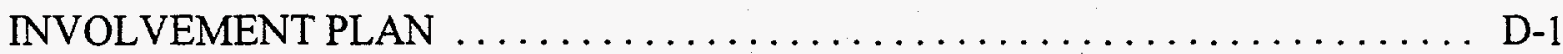

\section{FIGURES:}

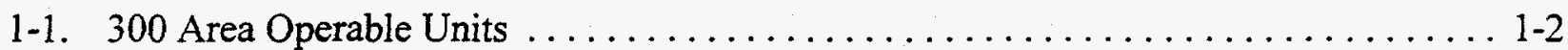

2-1. 300-FF-1 Operable Unit .................................... 2-7

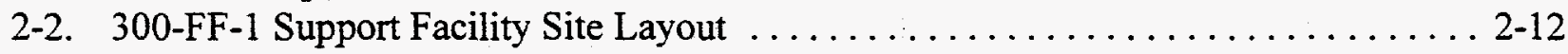

2-3. Waste Site Excavation Area Designations ......................... 2-16

3-1. 300-FF-1 Remedial Action Summary Schedule ...................... 3-6

3-2. 300-FF-1 Remedial Action Field Organizational Chart $\ldots \ldots \ldots \ldots \ldots \ldots \ldots . . \ldots \ldots$

TABLES:

2-1. Contaminants of Concern and Maximum Concentrations in the 300-FF-1 Operable Unit 
DOE/RL-96-70

Rev. 0

\section{ACRONYMS}

$\begin{array}{ll}\text { ALARA } & \text { as low as reasonably achievable } \\ \text { ARAR } & \text { applicable or relevant and appropriate requirement } \\ \text { BHI } & \text { Bechtel Hanford, Inc. } \\ \text { CERCLA } & \text { Comprehensive Environmental Response, Compensation, and Liability } \\ & \text { Act of 1980 } \\ \text { DOE } & \text { U.S. Department of Energy } \\ \text { DOT } & \text { U.S. Department of Transportation } \\ \text { Ecology } & \text { Washington State Department of Ecology } \\ \text { EPA } & \text { U.S. Environmental Protection Agency } \\ \text { ERA } & \text { expedited response action } \\ \text { ERC } & \text { Environmental Restoration Contractor } \\ \text { ERDF } & \text { Environmental Restoration Disposal Facility } \\ \text { HASP } & \text { health and safety plan } \\ \text { MCL } & \text { maximum contaminant level } \\ \text { MTCA } & \text { Model Toxics Control Act } \\ \text { NPL } & \text { National Priorities List } \\ \text { NRC } & \text { U.S. Nuclear Regulatory Commission } \\ \text { OSHA } & \text { Occupational Safety and Health Administration } \\ \text { RAO } & \text { remedial action objective } \\ \text { RAS } & \text { remedial action subcontractor } \\ \text { RCRA } & \text { Resource Conservation and Recovery Act of 1976 } \\ \text { RDR/RAWP } & \text { Remedial Design Report/Remedial Action Work Plan } \\ \text { RDS } & \text { remedial design subcontractor } \\ \text { RESRAD } & \text { Residual Radioactivity (dose assessment model) } \\ \text { RI/FS } & \text { remedial investigation/feasibility study } \\ \text { ROD } & \text { Record of Decision } \\ \text { SAP } & \text { sampling and analysis plan } \\ \text { SDWA } & \text { Safe Drinking Water Act } \\ \text { TBC } & \text { to-be-considered } \\ \text { UCL } & \text { upper confidence limit } \\ \end{array}$


DOE/RL-96-70.

Rev. 0 
DOE/RL-96-70

Rev. 0

\subsection{INTRODUCTION}

The Hanford Site is a $1,450-\mathrm{km}^{2}\left(560-\mathrm{mi}^{2}\right)$ Federal facility located in southeastern Washington State along the Columbia River. The primary mission of the Hanford Site from 1943 until 1990 was the production of nuclear materials for the nation's defense. In July 1989, the Hanford Site was listed on the National Priorities List (NPL) pursuant to the Comprehensive Environmental Response, Compensation, and Liability Act of 1980 (CERCLA) as amended by the Superfund Amendments and Reauthorization Act of 1986. This resulted in initiation of environmental remediation activities pursuant to the CERCLA process. The NPL listing identifies four separate areas of the Hanford Site: the 100 Area, the 200 Area, the 300 Area, and the 1100 Area. The 300 Area is the subject of this document.

The 300 Area has been divided into three operable units: 300-FF-1, 300-FF-2, and 300-FF-5 (Figure 1-1), all of which are in various stages of the CERCLA process. The 300-FF-1 Operable Unit, the subject of this report, includes liquid waste disposal sites, landfills, and a burial ground. The 300 Area Process Trenches are located within the 300-FF-1 Operable Unit boundaries and managed under the Resource Conservation and Recovery Act of 1976 (RCRA) and the State of Washington Hazardous Waste Management Act of 1976 in accordance with the Hanford Facility RCRA Part B Permit. Remediation of the 300 Area Process Trenches has been integrated into the operable unit to ensure that the remedial actions performed remain physically consistent and cost effective. The remediation of the Process Trenches must also meet the requirements described in the 300 Area Process Trenches Modified Closure/Postclosure Plan (DOE-RL 1995a) and those listed in Chapter 6 of the Hanford Site-Wide Dangerous Waste Permit.

The remedial investigation/feasibility study (RI/FS) phase of the CERCLA process for the 300-FF-1 Operable Unit has been completed. The results of the remedial investigation (RI) are documented in the Phase I Remedial Investigation Report for the 300-FF-1 Operable Unit (DOE-RL 1993a) and the Phase II Remedial Investigation Report for the 300-FF-I Operable Unit: Physical Separation of Soils Treatability Study (DOE-RL 1994).

The Phase I RI identified the extent of contamination within the operable unit and associated risks to human health and the environment. The results of the Phase I RI were used to support the preparation of the Phase I and II feasibility studies as documented in Phase I and II Feasibility Study Report for the 300-FF-1 Operable Unit (DOE-RL 1993b). These feasibility studies evaluated potential remedial alternatives for mitigating the identified risks associated with the operable unit. These studies also recommended that a treatability study be performed to evaluate the effectiveness of the physical separations (soil washing) remedial alternative. The results of this treatability study are documented in the Phase II RI report (DOE-RL 1994).

The Phase III feasibility study further refined potentially applicable remedial alternatives as documented in the Phase III Feasibility Study Report for the 300-FF-1 Operable Unit (DOE-RL 1995b). The results of the RI/FS activities led to the preparation of the Proposed Plan for the 300-FF-1 and 300-FF-5 Operable Units (DOE-RL 1995c), which recommends selective excavation and disposal of contaminants above regulatory limits from the liquid effluent disposal 
DOE/RL-96-70

Rev. 0

Figure 1-1. 300 Area Operable Units.

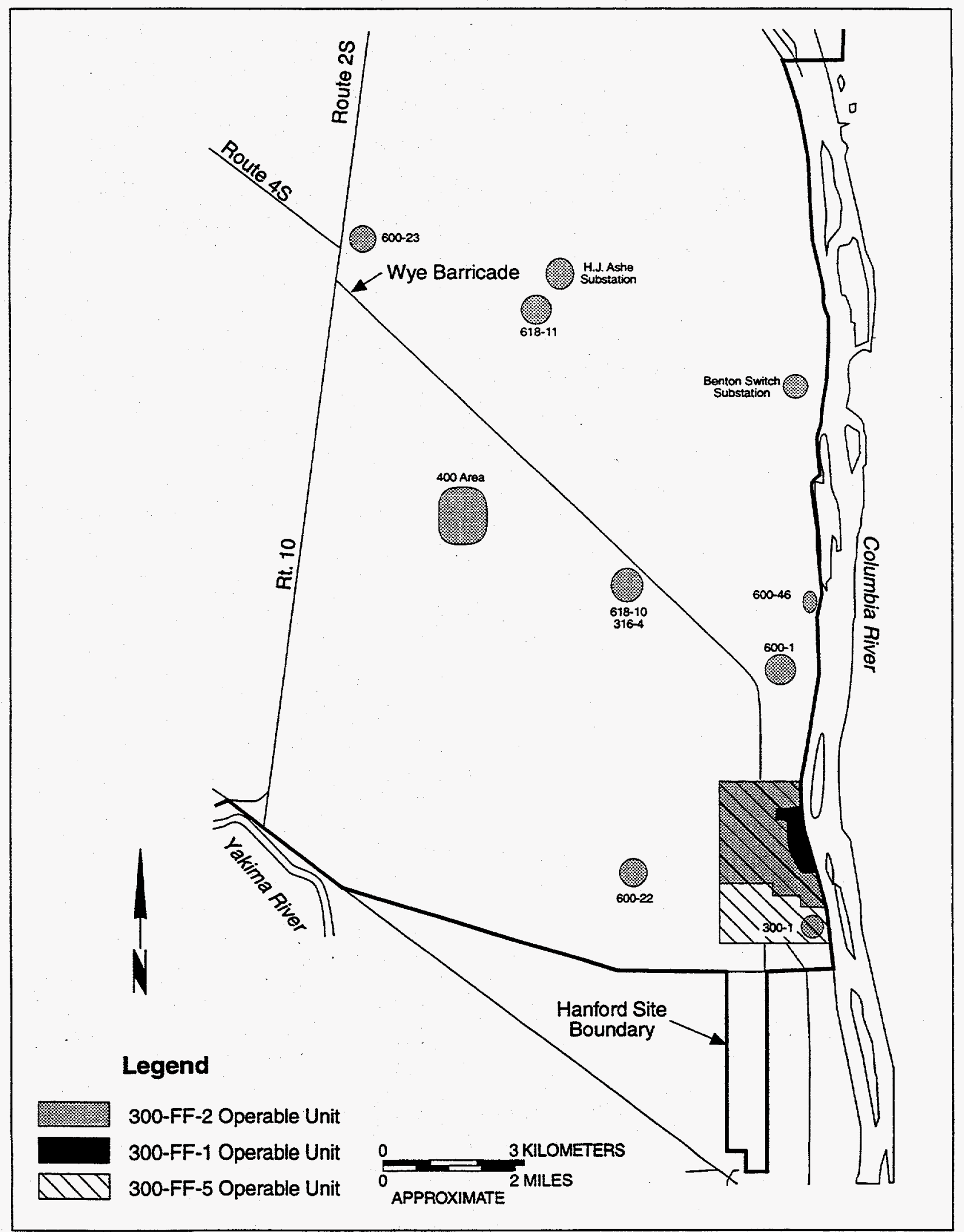


sites and landfills as well as excavation and disposal of the burial ground debris and soils that are found to be above cleanup levels. Upon completion of the excavation activities, the operable unit will be recontoured and revegetated. Noncontaminated soils and debris may be used as backfill materials during site restoration activities.

The proposed plan underwent public review and received favorable reception to the selected remedial actions. The Record of Decision for the U.S. Department of Energy Hanford 300-FF-I and 300-FF-5 Operable Units (EPA 1996), issued by the U.S. Environmental Protection Agency (EPA) with Washington State Department of Ecology (Ecology) concurrence, documents the selected remedial actions to be taken at the 300-FF-1 Operable Unit.

\subsection{PURPOSE AND OBJECTIVES}

This Remedial Design Report/Remedial Action Work Plan (RDR/RAWP) describes the design and implementation processes for the remedial actions to be taken at the 300-FF-1 Operable Unit pursuant to the Record of Decision (ROD) (EPA 1996). This document combines the RDR and RAWP documents identified in the Hanford Federal Facility Agreement and Consent Order (Ecology et al. 1990) and is a primary document pursuant to this order.

\section{$1.2 \quad$ SCOPE}

This RDR/RAWP provides a summary description of each waste site included in the 300-FF-1 Operable Unit, the basis for remedial actions to be taken, and the remedial action approach and management process for implementing these actions. The basis for performing the remedial actions includes identification of the remedial action objectives (RAOs), goals, applicable or relevant and appropriate requirements (ARARs), and the remedial design for meeting the objectives/goals.

The remedial action approach and management sections provide a description of the remedial action process description, the project schedule, the project team, required planning documentation, the remedial action change process, the process for verifying attainment of the remedial action goals, and the required CERCLA and RCRA closeout documentation.

Appendix A provides additional details on each waste site. In addition to remediation of the waste sites, waste generated during the RI/FS portions of the project will also be disposed at the Environmental Restoration Disposal Facility (ERDF). Appendix B provides a summary of the modeling performed in the 300-FF-1 Phase III FS and a description of the modeling effort to be used to show attainment of the remedial action goals. Appendix $C$ provides the sampling and analysis plan (SAP) for all sampling and field-screening activities performed during remediation and for verification of attainment with the remedial action goals. Appendix $D$ provides the public involvement plan, prepared to ensure information is provided to the public during remedial design and remedial action processes. 
DOE/RL-96-70

Rev. 0 
DOE/RL-96-70

Rev. 0

\subsection{BASIS FOR REMEDIAL ACTION}

The remedial action described herein is required by issuance of the 300-FF-1 ROD prepared by the EPA (EPA 1996). The 300-FF-1 ROD is summarized in the following sections.

\subsection{RECORD OF DECISION SUMMARY AND DECISION DEFINITION}

The 300-FF-1 Operable Unit ROD (EPA 1996) describes the selected alternative for remediation of the waste sites described. The waste sites include the following:

- 618-4 Burial Ground

- $\quad$ Process Trenches, associated Process Sewer System, and Process Trenches Spoils Pile

- North Process Pond, associated Process Sewer System, and the Scrapings Disposal Area

- $\quad$ Landfills $1 \mathrm{a}, 1 \mathrm{~b}, \mathrm{lc}$, and $1 \mathrm{~d}$

- $\quad$ South Process Pond

- $\quad$ Ash Pits

- $\quad$ Sanitary Sewer System

- Filter Backwash Pond

- $\quad$ Surface Radiation Areas

- $\quad$ Retired Filter Backwash Pond

- Aluminum Hydroxide Site (300-3).

The proposed alternatives are (1) selective excavation and disposal for the process waste sites and landfills and (2) excavation and disposal for the 618-4 Burial Ground. If elevated levels of cobalt -60 are found in the South Process Pond after excavation, institutional controls may be implemented while the cobalt 60 decays naturally.

The process waste units require selective excavation, removal, and disposal of contaminated soil/debris with concentrations above cleanup levels. Soil will be removed from the areas where it is known to be contaminated (above $350 \mathrm{pCi} / \mathrm{g}$ for uranium) with a minimum of sampling and analysis, except for sampling to confirm that all contaminated soil has been removed and ensure the waste meets ERDF waste disposal criteria. Areas that are thought to be below the cleanup standard will be sampled to verify that the area is clean. The areas where the data are inconclusive will require field investigation sampling during remediation to determine where the soil is contaminated above the cleanup standards which, in turn, determines what soils must be removed for disposal. Depth of contamination was estimated between 1 and $3 \mathrm{~m} \mathrm{(} 3$ and $10 \mathrm{ft}$ ) for cost-estimating purposes.

Landfills $1 \mathrm{a}, 1 \mathrm{~b}$, and $1 \mathrm{~d}$ require excavation, removal, and disposal of contaminated soil, solid waste, and construction debris with concentrations above cleanup standards. Sampling and analysis during remediation and for final verification is required to ensure that all solid waste, construction debris, and soils above cleanup levels have been removed. Depth of contamination 
DOE/RL-96-70

Rev. 0

was estimated at less than $5 \mathrm{~m}(15 \mathrm{ft})$ for Landfills $1 \mathrm{a}, 1 \mathrm{~b}$, and $1 \mathrm{~d}$. Landfill $1 \mathrm{c}$ does not require remediation.

The 618-4 Burial Ground will be excavated. All solid waste and construction debris will be disposed at the ERDF. Burial grounds in the 300 Area have been difficult to characterize because of their complexity and limited documented history. As part of the remediation, the 618-4 Burial Ground will be excavated to gain information on how the available data correlate to actual contents. Therefore, as part of this remediation, investigative sampling may be conducted during excavation. Information collected during the excavation is considered very important and will be used in remedial selections for other 300 Area burial grounds. As remediation is completed, verification samples will be collected as described in the SAP (Appendix C) to verify that remedial goals are met. Depth of contamination was estimated at $7 \mathrm{~m}(20 \mathrm{ft})$.

The Ash Pits will be sampled to verify that they are below cleanup levels. The Sanitary Trenches will not require sampling, but the associated headworks will be demolished. The posted surface radiation zones shown in Figure 2-3 will also be remediated. These areas were not specifically identified in the ROD but will be remediated at this time because of their proximity to the $300-$ FF-1 waste sites.

The specific goals and objectives of this alternative are summarized in the following sections.

\subsubsection{Remedial Action Objectives}

The RAOs set forth in the ROD (EPA 1996) are narrative statements that define the extent to which the sites require cleanup to meet the underlying objective of protection of human health and the environment. The applicable RAOs are described as follows. (NOTE: The RAOs presented in the ROD combine the 300-FF-1 and 300-FF-5 Operable Units. Only those portions applicable to the $300-\mathrm{FF}-1$ Operable Unit are listed below.)

1. Protect human and ecological receptors from exposure to contaminants in soils and debris by exposure, inhalation, or ingestion of radionuclides, metals, or organics.

This RAO will be achieved through compliance with the Model Toxics Control Act (MTCA) cleanup values for organic and inorganic chemical constituents in soil to support industrial land use (WAC 173-340-745) and the draft EPA and the draft U.S. Nuclear Regulatory Commission (NRC) proposed protection of human health standards for radionuclides in soils of $15 \mathrm{mrem} / \mathrm{yr}$ above background.

2. Protect human and ecological receptors from exposure to contaminants in the groundwater and control the sources of groundwater contamination in 300-FF-1 to minimize future impacts to groundwater resources.

This RAO will be achieved by attaining maximum contaminant levels (MCLs) and nonzero MCL goals promulgated under the Safe Drinking Water Act (SDWA). The 


\section{DOE/RL-96-70}

Rev. 0

specific location and measurements of the compliance monitoring will be documented in an operations and maintenance plan for the 300-FF-5 Operable Unit, which has been approved by EPA, and the Groundwater Monitoring Plan for the [RCRA] 300 Area Process Trenches (WHC 1996). Also, the contaminants remaining in the soil after remediation will not result in further degradation of groundwater quality.

3. Protect the Columbia River such that contaminants in the groundwater or remaining in the soil after remediation do not result in an impact to the Columbia River that could exceed the Washington State Surface Water Quality Standards.

The protection of the river will be achieved by preventing further degradation of groundwater quality in the uranium plume such that receptors that may be affected at the groundwater discharge point to the Columbia River are not subject to any additional incremental adverse risks. The specific location and measurements of the compliance monitoring will be documented in an operations and maintenance plan for the 300-FF-5 Operable Unit, which has been approved by EPA, and the Groundwater Monitoring Plan for the [RCRA] 300 Area Process Trenches (WHC 1996).

\subsubsection{Remedial Action Goals}

Remedial action goals are the contaminant-specific numerical cleanup criteria developed to ensure that the remedial actions to be implemented will meet the RAOs set forth in the ROD. The remedial action goals are based on the ARARs, to-be-considered (TBC) information and assumed land use for the remedial action identified in the ROD.

The first RAO will be achieved by performing cleanup actions that meet the following requirements: (1) MTCA for organic and inorganic constituents (see Section 2.1.2.1) and (2) EPA and NRC proposed rules for radionuclides (see Section 2.1.2.2).

The second and third RAOs will be achieved through the following requirement:

- Protection of groundwater and the Columbia River by confirming a reduction in risk to these resources from contaminant loading in the $300-\mathrm{FF}-1$ waste sites. The reduction in risk will be demonstrated by comparing the uranium results of the verification sampling effort to contaminant concentrations modeled prior to performing the remedial action and by ensuring that all other contaminant levels are at or below MTCA Method C cleanup levels.

2.1.2.1 State of Washington Model Toxics Control Act. Soils contaminated with organic and inorganic compounds in excess of MTCA Method C cleanup standards for industrial land use will be excavated and disposed of at the ERDF. Contaminated soil cleanup standards for industrial land use are specified in Table 2-1. Compliance with these cleanup standards will be confirmed through verification sampling performed after the removal activities have been completed (see the SAP, Appendix C). 
DOE/RL-96-70

Rev. 0

Table 2-1. Contaminants of Concern and Maximum Concentrations in the 300-FF-1 Operable Unit.

\begin{tabular}{|c|c|c|c|}
\hline Contaminants of Concern & $\begin{array}{l}\text { Maximum Concentration } \\
\text { Detected in Soils }\end{array}$ & $\begin{array}{l}\text { Cleanup } \\
\text { Levels }\end{array}$ & $\begin{array}{c}\text { Source of } \\
\text { Cleanup Level }\end{array}$ \\
\hline Cobalt -60 & $81 \mathrm{pCi} / \mathrm{g}$ & \multirow{4}{*}{$15 \mathrm{mrem} / \mathrm{yr}^{\mathrm{b}}$} & \multirow{4}{*}{$40 \mathrm{CFR} 196^{\mathrm{c}}$} \\
\hline Uranium-234 & $9,700 \mathrm{pCi} / \mathrm{g}$ & & \\
\hline Uranium-235 & $1,600 \mathrm{pCi} / \mathrm{g}$ & & \\
\hline Uranium-238 & $9,143 \mathrm{pCi} / \mathrm{g}$ & & \\
\hline Arsenic $^{d}$ & $319 \mathrm{mg} / \mathrm{kg}$ & $219 \mathrm{mg} / \mathrm{kg}$ & MTCA $^{\mathrm{e}}$ \\
\hline Benzo(a)pyrene ${ }^{d}$ & $27 \mathrm{mg} / \mathrm{kg}$ & $18 \mathrm{mg} / \mathrm{kg}$ & $\mathrm{MTCA}^{\mathrm{e}}$ \\
\hline Chrysene $^{d}$ & $43 \mathrm{mg} / \mathrm{kg}$ & $18 \mathrm{mg} / \mathrm{kg}$ & MTCA $^{\mathrm{e}}$ \\
\hline Polychlorinated biphenyls & $42 \mathrm{mg} / \mathrm{kg}$ & $17 \mathrm{mg} / \mathrm{kg}$ & MTCA $^{\mathrm{e}}$ \\
\hline Thallium $^{\mathrm{d}}$ & $25,000 \mathrm{mg} / \mathrm{kg}$ & $245 \mathrm{mg} / \mathrm{kg}$ & $\mathrm{MTCA}^{\mathrm{e}}$ \\
\hline \multicolumn{4}{|c|}{$\begin{array}{l}\text { Source: Record of Decision for the U.S. Department of Energy Hanford 300-FF-1 and } \\
\text { 300-FF-5 Operable Units (EPA 1996). }\end{array}$} \\
\hline \multicolumn{4}{|c|}{$\begin{array}{l}\text { 'Residual radioactivity modeling based on a regulator-approved industrial exposure scenario is } \\
\text { used to convert between dose levels (mrem/yr) and soil concentrations (pCi/g). For example, } \\
\text { the } 15-\mathrm{mrem} / \mathrm{yr} \text { dose equates to } 350-\mathrm{pCi} / \mathrm{g} \text { concentration from total uranium-234, } \\
\text { uranium-235, and uranium-238. }\end{array}$} \\
\hline \multicolumn{4}{|c|}{ '40 CFR 196 is a draft regulation identified in an advanceà notice of proposed rulemaking. } \\
\hline \multicolumn{4}{|c|}{$\begin{array}{l}\mathrm{d} \text { Contaminants found only in the Process Trenches Spoils Pile. When uranium is removed to } \\
\text { the Comprehensive Environmental Response, Compensation, and Liability Act of } 1980 \text { cleanup } \\
\text { standard of } 350 \mathrm{pCi} / \mathrm{g} \text {, the chemical contaminants of concern will likely be removed to below } \\
\text { the Model Toxics Control Act (MTCA) Method C cleanup standards, so in-process screening } \\
\text { for uranium can be used to guide remediation. }\end{array}$} \\
\hline
\end{tabular}


2.1.2.2 Proposed Radiation Cleanup Standards. The proposed radiation cleanup standard, as described in the "Radiation Site Cleanup Regulation: Preliminary Draft" (40 CFR 196), would limit radiation doses to an industrial worker from contaminated sites to $15 \mathrm{mrem} / \mathrm{yr}$ above natural background. Limiting exposure levels to $15 \mathrm{mrem} / \mathrm{yr}$ above background acknowledges that background varies from site to site.

Determining when remedial action has achieved the $15-\mathrm{mrem} / \mathrm{yr}$ cleanup level involves converting radionuclide concentrations (in $\mathrm{pCi} / \mathrm{g}$ ) in soil into dose rates (in mrem/yr) using a dose assessment model. Use of a model requires an exposure scenario that specifies a hypothetical receptor (i.e., an industrial worker), pathways of exposure from radionuclides in soil to the receptor, and assumptions and parameters for estimating exposures and doses to the receptor from radionuclides in soil. An industrial land-use scenario has been agreed upon as documented in the ROD.

The agreed-upon industrial scenario is defined as a worker spending $1,500 \mathrm{~h} / \mathrm{yr}$ in a building located on a waste site and spending 500 hours outside on a waste site. The residual radioactivity (RESRAD) model was the software tool used to calculate exposure levels under the agreed-upon scenario. Appendix B provides a description of the RESRAD model used. A soil concentration of $350 \mathrm{pCi} / \mathrm{g}$ total uranium corresponds to a $15-\mathrm{mrem} / \mathrm{yr}$ dose based on the $300-\mathrm{FF}-1$ industrial scenario. Therefore, all soils containing more than $350 \mathrm{pCi} / \mathrm{g}$ total uranium will be excavated.

The RESRAD modeling used only uranium in developing the radiation cleanup standard because cobalt-60 is of concern only in the South Process Pond and also has a short half-life (5.26 years), which means that it will naturally decay to below cleanup concentrations fairly quickly. Cobalt 60 concentrations in the South Process Pond average about $3.8 \mathrm{pCi} / \mathrm{g}$. This level of cobalt- 60 will decay naturally to a level of insignificant dose contribution by the time cleanup of the operable unit is completed. If the comparison of the results of the verification sampling effort indicate that the 15-mrem/yr cleanup level is not achieved for both uranium and cobalt-60, institutional controls may be applied to the area for a short period of time while the cobalt decays. No other radionuclides contribute significantly to the total dose.

2.1.2.3 Protection of Groundwater and the Columbia River. The RAOs require that the groundwater underlying the 300-FF-1 Operable Unit and the Columbia River must be protected from further negative impacts resulting from contaminants present in the 300-FF-1 Operable Unit waste sites. A baseline risk assessment was performed to determine the impacts to these resources if no action were taken at the 300-FF-1 Operable Unit. In addition, the RESRAD modeling effort was performed to show the impacts to the groundwater and Columbia River using the selected remedial action. The RESRAD model results show that the RAOs will be met within the reasonable accuracy of the model. A qualitative evaluation of natural site processes that would tend to attenuate the migration of contaminants indicated also that the RAO would be met (DOE-RL 1995b, Appendix G). 
DOE/RL-96-70

Rev. 0

\subsubsection{Application of Remedial Action Goals}

Certain site-specific factors influence the extent of remediation required at each waste site. The process waste units require selective excavation and removal of contaminated soil/debris with concentrations above cleanup standards. The individual process waste units can be divided into three areas: (1) areas where the data show that the soil is above the cleanup standard, (2) areas where the data show that the soil is below cleanup standards, and (3) areas where the data are inconclusive. The locations of the waste sites are shown in Figure 2-1.

Soil will be removed from the areas where it is known to be contaminated (above $350 \mathrm{pCi} / \mathrm{g}$ for uranium) with a minimum of sampling and analysis, except for verification sampling to confirm that all contaminated soil has been removed. Radiological surveys of the waste site will be performed prior to the area being excavated. The results of these surveys will be used to verify that the excavated material meets the requirements of the ERDF waste profile established to ensure compliance with ERDF waste acceptance criteria. Areas that are already below the cleanup standard will be left in place and verified as clean. The areas where the data are inconclusive will require field investigation sampling during remediation to determine where the soil is contaminated above the cleanup standards which, in turn, determines what soils must be removed for disposal. As remediation is completed, verification samples will be collected as necessary to verify that remedial goals are met (Appendix C).

The 618-4 Burial Ground will be excavated, and the soil, solid waste, and construction debris greater than cleanup levels will be disposed. Burial grounds in the 300 Area have been difficult to characterize because of their complexity and limited documented history. As part of the remediation, the 618-4 Burial Ground will be excavated to gain information on how the available data correlate to actual contents. Therefore, as part of this remediation, investigative sampling may be conducted during excavation. Information collected during the excavation is considered very important and will be used in remedial selections for other 300 Area burial grounds. As remediation is completed, verification samples will be collected as necessary to verify that remedial goals are met.

\subsubsection{Contaminant-Specific Concentrations in Soil}

As discussed in Section 2.1.3, contaminant-specific concentrations will be used to identify soils to be excavated and determine if the remedial action goals and objectives have been met. Specifically, these contaminant-specific goals will be used as follows.

- $\quad$ Field analysis for uranium will be used to identify those soils with contaminant concentrations above the cleanup levels. Soils with uranium concentrations above $350 \mathrm{pCi} / \mathrm{g}$ will be excavated. Uranium-contaminated soils greater than the $350 \mathrm{pCi} / \mathrm{g}$ cleanup standard were qualitatively found to correlate with the same soils that were above MTCA Method $\mathrm{C}$ values for chemical contaminants. In addition, field methods will be used for metal and organic contaminants at the burial ground and landfills. 
Figure 2-1. 300-FF-1 Operable Unit.

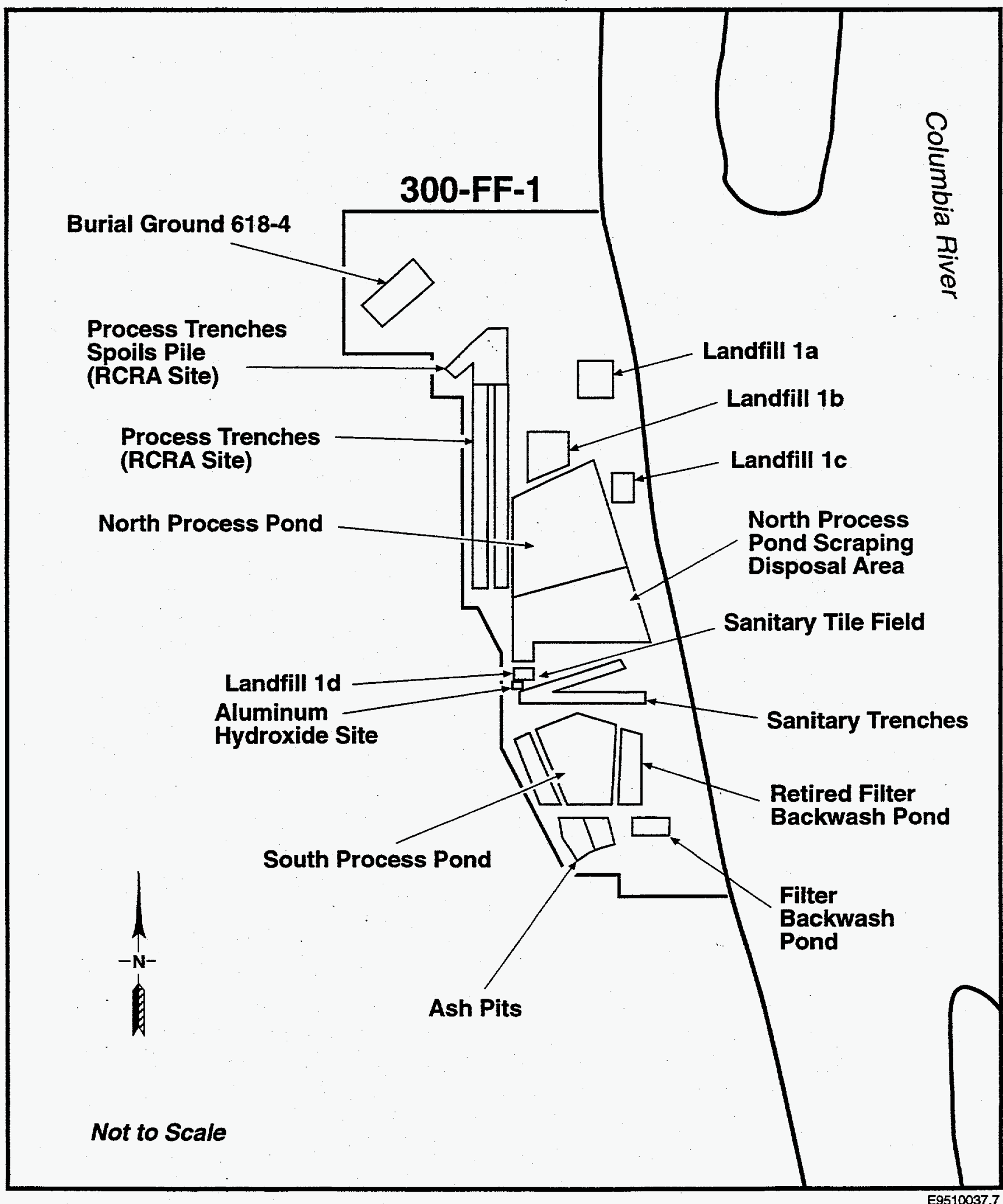


DOE/RL-96-70

Rev. 0

The field analysis results will also be used to support waste designation and compliance with ERDF waste acceptance criteria.

- Contaminant-specific concentrations obtained through verification sampling in addition to field analysis for process control and ERDF waste acceptance will be used in determining if remedial actions at the site are complete.

\subsubsection{Applicable or Relevant and Appropriate Requirements}

CERCLA requires, in part, that any applicable or relevant and appropriate standard, requirement, criteria, or limitation under any Federal environmental law, or any more stringent State requirement promulgated pursuant to a State environmental statute, be met relevant to the remedial action(s) to be taken. EPA guidance also includes TBC standards, which are advisories and nonpromulgated guidance issued by Federal or State governments that are nonstatutory requirements. TBCs may be considered in setting cleanup standards.

The 300-FF-1 ROD identifies the Federal and State requirements that are ARARs for remediation of the 300-FF-1 Operable Unit. Each of these ARARs will be evaluated in detail during the remedial design process to ensure compliance as appropriate. The ARARs for $300-\mathrm{FF}-1$, as presented in the ROD, are provided in the following subsections.

\subsubsection{Chemical-Specific Applicable or Relevant and Appropriate Requirements.}

Chemical-specific ARARs are health- or risk-based standards that either are specific numerical cleanup levels or specify methodologies to derive numeric cleanup levels. These requirements establish the acceptable amount or concentration of a chemical that can be found in or discharged to the environment. The following are chemical-specific ARARs identified for the 300-FF-1 Operable Unit.

- $\quad$ SDWA, 40 CFR 141, MCLs for public drinking water supplies are relevant and appropriate for establishing cleanup goals that are protective of groundwater.

- $\quad$ MTCA Cleanup Regulations, WAC 173-340-745, risk-based cleanup levels are applicable for establishing cleanup levels for soil.

- "Water Quality Standards for Waters of the State of Washington," WAC 173-201A-040, are applicable for establishing cleanup goals that are protective of the Columbia River.

2.1.5.2 Action-Specific Applicable or Relevant and Appropriate Requirements. Actionspecific ARARs are technology- or activity-based regulatory requirements or limitations that are triggered by a particular remedial action such as excavation, transport, and/or disposal of hazardous waste. The action-specific ARARs identified in the 300-FF-1 ROD are described below. These ARARs must be met by the remedial action subcontractor (RAS) performing the remediation at the 300-FF-1 Operable Unit. 
- State of Washington Dangerous Waste Regulations (WAC 173-303) are applicable for the identification, treatment, storage, and land disposal of hazardous and dangerous wastes.

- $\quad$ RCRA Land Disposal Restrictions (40 CFR 268) may be applicable for disposal of metal-contaminated materials to meet ERDF waste acceptance criteria.

\subsubsection{Location-Specific Applicable or Relevant and Appropriate Requirements.} Location-specific ARARs are restrictions placed on the concentration of hazardous substances or remedial action because they occur in special or sensitive locations or environments. The location-specific ARARs identified in the 300-FF-1 ROD are as follows.

- Archeological and Historical Preservation Act (16 USC 469) is applicable to recovery and preservation of artifacts in areas where an action may cause irreparable harm, loss, or destruction of significant artifacts.

- $\quad$ National Historic Preservation Act (16 USC 470, et. seq.), 36 CFR 800, is applicable to actions in order to preserve historic properties controlled by a Federal agency.

- $\quad$ Endangered Species Act of 1973 (16 USC 1531, et. seq.), 50 CFR 200, 50 CFR 402, is applicable to conserve critical habitat upon which endangered or threatened species depend. Consultation with the Department of the Interior is required.

2.1.5.4 Other Criteria, Advisories, or Guidance To Be Considered. TBC information generally consists of Federal, State, and local criteria, advisories, and proposed standards that are not legally binding (i.e., not promulgated regulations), but that may be useful in establishing cleanup goals or remedial alternatives that are protective of human health and the environment. The TBCs identified in the 300-FF-1 ROD are as follows:

- Draft 40 CFR 196 (58 FR 54474): Advance Notice of Proposed Rulemaking by EPA for cleanup of radionuclides in soils to $15 \mathrm{mrem} / \mathrm{yr}$ above natural background

- $\quad$ Draft 10 CFR 20 (59 FR 43200): Draft Proposed Rulemaking by NRC for cleanup of radionuclides in soils to $15 \mathrm{mrem} / \mathrm{yr}$ above natural background, and as low as reasonably achievable (ALARA)

- Draft 10 CFR 834 (58 FR 16268): Draft Proposed Rulemaking by the U.S. Department of Energy (DOE) for radiation protection of the public. Establishes a dose limit of $100 \mathrm{mrem} / \mathrm{yr}$ above natural background, and ALARA

- Proposed amendment to 40 CFR 141 (56 FR 33050): A new MCL for uranium proposed by EPA 
- $\quad$ ERDF waste acceptance criteria that delineate primary requirements including regulatory requirements, specific isotopic constituents and contamination levels, the dangerous/hazardous constituents and concentrations, and the physical/chemical waste characteristics that are acceptable for disposal of wastes at ERDF (BHI 1996)

- 59 FR 66414, Radiation Protection Guidance for Exposure to the General Public, EPA protection guidance recommending (nonmedical) radiation doses to the public from all sources and pathways not to exceed $100 \mathrm{mrem} / \mathrm{yr}$ above background. It also recommends that lower dose limits be applied to individual sources and pathways. One such individual source is residual environmental radiation contamination after the cleanup of a site. Lower dose limits and individual pathways are referred to as secondary limits

- The Future for Hanford: Uses and Cleanup - A Final Report of the Hanford Future Site Uses Working Group (Drummond 1992).

\subsubsection{Waste Treatment If Required}

The selected alternative does not use treatment because, when considered against other balancing criteria, the benefits are insufficient to warrant the added costs. This may have to be reconsidered if the waste volumes requiring excavation and disposal at ERDF increase significantly or land-banned waste is found during excavation of the 618-4 Burial Ground or one of the landfills associated with the process waste sites.

It is likely that some material may be recovered from the landfills and burial ground that does not meet the ERDF acceptance criteria (BHI 1996), but can be readily treated using basic stabilization technologies (e.g., the waste stream exceeds the maximum moisture content allowed and therefore is aerated on waste pads for moisture evaporation or adsorbents are added to the waste). In these cases, the material will be stabilized as appropriate for disposal at the ERDF.

In the event that a land-banned material is discovered or the waste stream does not meet the ERDF waste acceptance criteria (BHI 1996), the waste will be sorted and stored onsite until treated to meet ERDF waste acceptance criteria and/or an appropriate disposal facility can be located, or until a treatability variance is approved. These materials will be treated and disposed of prior to formal closure of the waste site.

If treatment is required, an evaluation of available, proven treatment technologies that will meet the requirements specified in the ERDF acceptance criteria and/or ARARs for land-banned materials will be made. This evaluation will include cost of treatment, compliance with ARARs, and regulatory acceptability. This decision will follow the remedial action change management process described in Section 3.5. This process will not be followed for simple waste stabilization activities as described above (e.g., adding adsorbents to wastes that exceed the maximum moisture content allowed by ERDF). 
DOE/RL-96-70

Rev. 0

\section{$2.2 \quad$ REMEDIAL DESIGN}

The design strategy for remediating the 300-FF-1 Operable Unit waste sites is similar to that used at many commercial CERCLA sites. The core of this approach is to specify only general requirements (including the regulatory requirements) and remedial performance goals that allow the RAS to select the equipment, design the support facilities, and plan operations necessary to complete the work. This methodology will expedite the cleanup schedule, maximize cost effectiveness, and allow innovative approaches to increase productivity.

A remedial design package has been prepared [by a remedial design subcontractor (RDS)] to provide the minimum regulatory and remedial design requirements, elements, specifications, and general remediation procedures to the RAS selected to perform the remedial action. This design also includes a site layout for the major support facilities and infrastructure (Figure 2-2).

This information will be used by the RAS in preparing the facility and operational designs. This will allow the RAS to optimize the remediation process based on its available equipment and expertise, while still meeting the objectives of the remedial action and complying with the ARARs identified in Section 2.1. The final designs and procedures will be submitted to Bechtel Hanford, Inc. (BHI) for approval prior to initiation of the remedial activities.

The design requirements include regulatory and Hanford Site specific requirements for performing the remedial action. The following requirements must be considered in all designs and procedures supporting the remedial action.

- Cleanup Levels: This includes the soil cleanup levels specified in Table 2-1 for the primary contaminants of concern.

- $\quad$ Air Emissions: For CERCLA-regulated activities, the permits and administrative requirements of the Clean Air Act are not applicable. The substantive requirements for air quality must be met, however. These substantive requirements include the State technology requirements (best available control technology for radionuclides and toxic air pollutants) (WAC 246-247 and WAC 173-400, 460).

Fugitive dust sources and odors must be minimized in accordance with WAC 173-400-040(4,8).

Radionuclide emissions shall be controlled to ALARA levels. Maximum permissible limits are identified in 40 CFR 61, Subpart H, and WAC 246-247.

- Worker Exposure: Worker radiation exposure will be controlled through use of the Hanford Site Radiological Control Manual (HSRCM 1994) and contractor-specific radiation worker procedures. Exposure to industrial and hazardous sources will be controlled through subcontractor health and safety procedures/plans that are consistent with the Environmental Restoration Contractor (ERC) health and șafety plan (HASP). 
DOE/RL-96-70

Rev. 0

Figure 2-2. 300-FF-1 Support Facility Site Layout.

$-2-1$
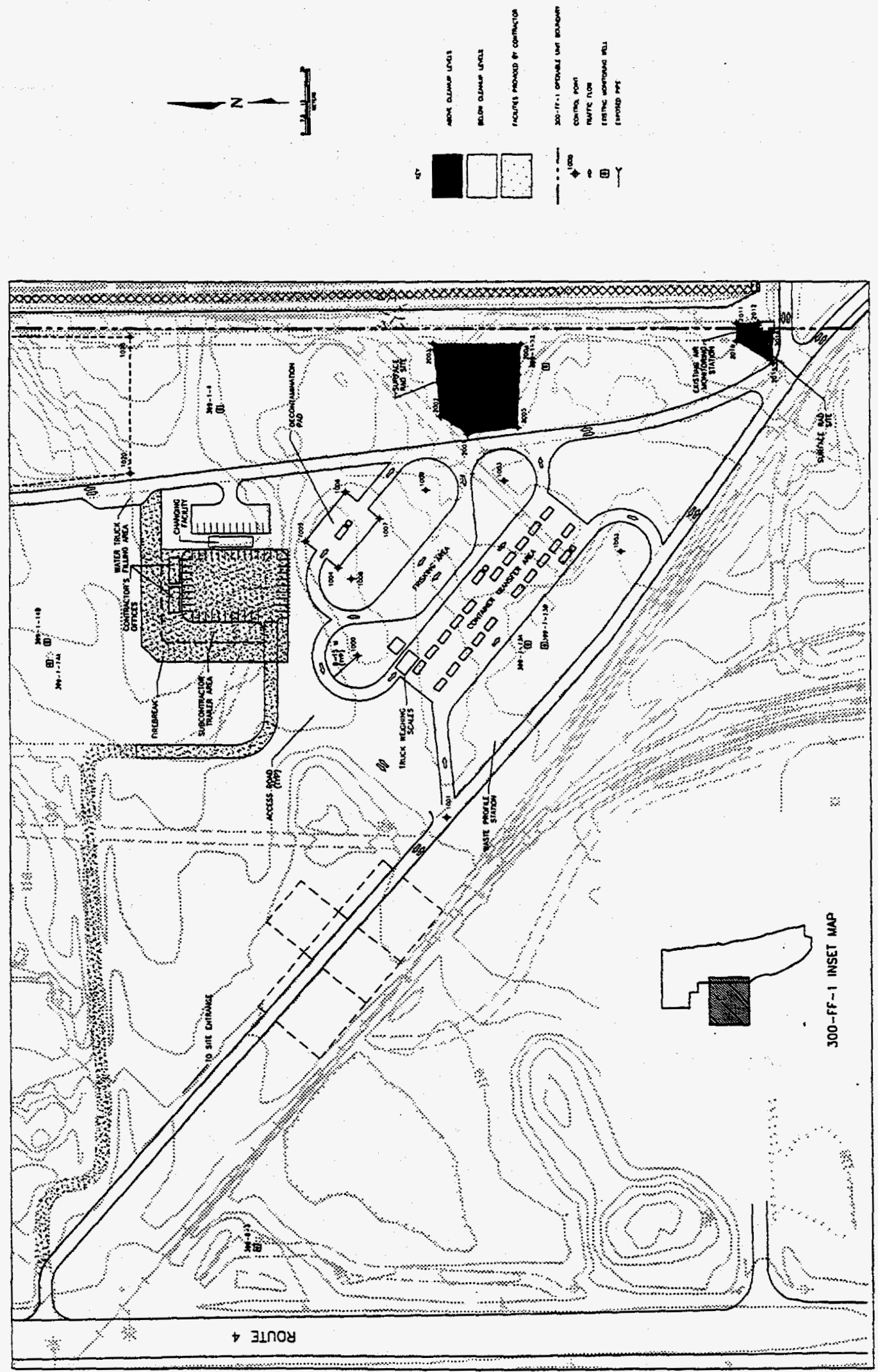


\section{DOE/RL-96-70}

Rev. 0

In addition, the RAS shall be committed to protecting the health of the public and will apply a level of ALARA effort commensurate with the potential for public exposure. All ALARA considerations shall be controlled by and implemented in accordance with 10 CFR 834, "Radiation Protection of the Public and the Environment" (proposed regulation), and the companion Environmental ALARA Guide.

ERDF Waste Acceptance Criteria: The contaminated soils and debris will be disposed of in the ERDF provided they meet the ERDF waste acceptance criteria. Wastes entering the ERDF will be controlled on the basis of source, classification, and contamination levels. To simplify and coordinate ERDF and 300-FF-1 remedial action operations, all incoming wastes to ERDF will be handled in a uniform, consistent, and predictable manner compliant with the Environmental Restoration Disposal Facility Waste Acceptance Criteria (BHI 1996).

Any material that exceeds the disposal criteria will be stored onsite until treated to meet the acceptance criteria or until a treatability variance is obtained. The RAS will perform waste stabilization activities required to meet the ERDF waste acceptance criteria. Other items, such as land-banned materials, that cannot be disposed of will be stored by the RAS until directed by BHI to do otherwise. BHI will take the appropriate steps to ensure that this waste is handled in accordance with applicable ARARs or obtain the necessary waiver(s).

Debris and waste not originating from the landfills or burial ground that are nondangerous, nonradioactive, and are not contaminated above the MTCA Method C limits for industrial use may be sent to an offsite landfill or used as backfill during site stabilization activities. The ERDF may be used for disposal of these materials if it is cost effective to do so and the ERDF will accept the material.

- Quality Assurance: All quality-affecting documents and activities associated with remediation of the 300-FF-1 Operable Unit shall comply with the applicable requirements of the ERC Quality Program (BHI-QA-01) and its implementing procedures found in Quality Program Procedures (BHI-QA-02). Activity-specific quality assurance project plans shall be prepared by the RDS and the RAS to ensure compliance with $\mathrm{BHI}$ procedures.

Cultural Resources and Ecological Considerations: A Cultural Resource Survey was performed for the 300-FF-1 Operable Unit at the beginning of the RI. The survey was performed by the Hanford Cultural Resource Laboratory and given the designation HCRC \#90-300-12.

In that the Cultural Resource Survey cited above was limited in scope, an additional survey was performed in conjunction with tribal members to evaluate all areas potentially affected by the proposed remedial activities for the 300-FF-1 Operable Unit. 
DOE/RL-96-70

Rev. 0

This includes waste sites that are planned to be excavated as well as operational areas.

The survey findings are documented in HCRC \#96-300-030.

In addition, the statutory provisions of the Native American Graves Protection and Repatriation Act will be followed for the treatment of inadvertent discoveries of Native American remains and cultural objects. Specifically, if discoveries are made during ground-disturbing activities, the following must take place: activity in the area of discovery must cease immediately; reasonable efforts must be made to protect the items discovered; notice of discovery must be given to the Agency Head and appropriate Tribes; and a period of 30 days must be set aside following notification for negotiations regarding the appropriate disposition of these items.

Ecological surveys of the operable unit have identified threatened and endangered plants and animals that may be found in or near the 300-FF-1 Operable Unit (DOE-RL 1995b). The design process will consider steps necessary to minimize the ecological impacts to both the native vegetation and nearby wildlife.

- Other Requirements: Compliance with other DOE and Hanford Site-specific requirements will also be required of the subcontractor.

Worker safety and health issues associated with construction activities shall be governed by the applicable standards from 29 CFR 1926 and WAC 296-155. Compliance with these regulations will be addressed and implemented through an activity-specific HASP.

Appropriate industrial codes (e.g., American National Standards Institute, American Society of Mechanical Engineers, National Electric Code, National Fire Protection Association) have been and will be taken into account during the design activities. The appropriate standards have also been followed during development of the design drawings and other supporting documentation.

The general remediation procedures are summarized in Section 2.2.1. The major design elements applicable to all waste sites are described in Section 2.2.2. Elements specific to the individual waste sites are described in Section 2.2.3. These elements are intended to establish the criteria that will be used during the RAS design process.

\subsubsection{General Remediation Procedures}

2.2.1.1 Excavation. Soils/sediments will be excavated in horizontal lifts in level areas and parallel to the overall slope in other areas. Vertical cuts may be used in remediating the landfills and burial ground. Additional excavations may be required for access and to maintain stable slopes. All slopes will be in accordance with the requirements of 29 CFR 1926, Subpart P, "Excavations." Contaminated soils and debris will be loaded into transport containers for shipment to ERDF. 
The presently identified areas for excavation, as well as areas where the need for excavation has not been determined, are shown in Figure 2-3. The actual extent of soil and debris removal will be determined as excavation progresses using screening techniques presented in the SAP (Appendix C).

2.2.1.2 Material Handling - Soils Below Cleanup Levels. All soils below cleanup levels will be stockpiled for use during restoration as backfill material. These stockpiles will be managed to prevent wind dispersion or other spread of material beyond the footprint of the stockpile area. To the extent practical, the clean soil backfill will be placed in the same excavation from which it was originally obtained.

\subsubsection{Material Handling - Materials Unacceptable to Environmental Restoration Disposal Facility. Material that does not meet ERDF waste acceptance criteria will be temporarily stored within the footprint of the waste area from which the material was derived pending evaluation of treatment and/or disposal options. The materials will be covered to prevent dispersion and infiltration of water.}

2.2.1.4 "Confirm as Clean" Procedure. In all areas indicated as below cleanup levels and those in which remediation is thought to have removed all materials contaminated above cleanup levels, field screening and chemical sampling and analysis will be performed to confirm that the soil is below cleanup standards. If contamination is found to be above cleanup levels, the location and extent of the contamination will be determined. A $30.48-\mathrm{cm}-(1-\mathrm{ft})$ thick layer will be removed, and the area will again be screened/sampled to determine if further soil removal is required. This process will be repeated until all soil above cleanup levels has been removed or groundwater is reached.

This procedure does not apply to those sites listed in the ROD that require no actions to be taken, including verification sampling. These sites are the Aluminum Hydroxide Site, the Filter Backwash Pond, Landfill 1c, and the Sanitary Trenches.

2.2.1.5 "Undetermined Contamination Level." In all areas where the contamination level is unknown, the area will be field screened to determine if the soil is above cleanup levels. Trenches will be excavated at various locations as indicated in the SAP (Appendix C). Concurrently with the excavation of the trench, the spoils and sidewalls of the trench will be screened to determine the location and extent of areas requiring soil removal. In areas above cleanup levels, a $30.48-\mathrm{cm}-(1-\mathrm{ft})$ layer of soil will be removed and loaded into transport containers for shipment to ERDF. The "Confirm as Clean" procedure will then be applied to this area. 
DOE/RL-96-70

Rev. 0

Figure 2-3. Waste Site Excavation Area Designations.

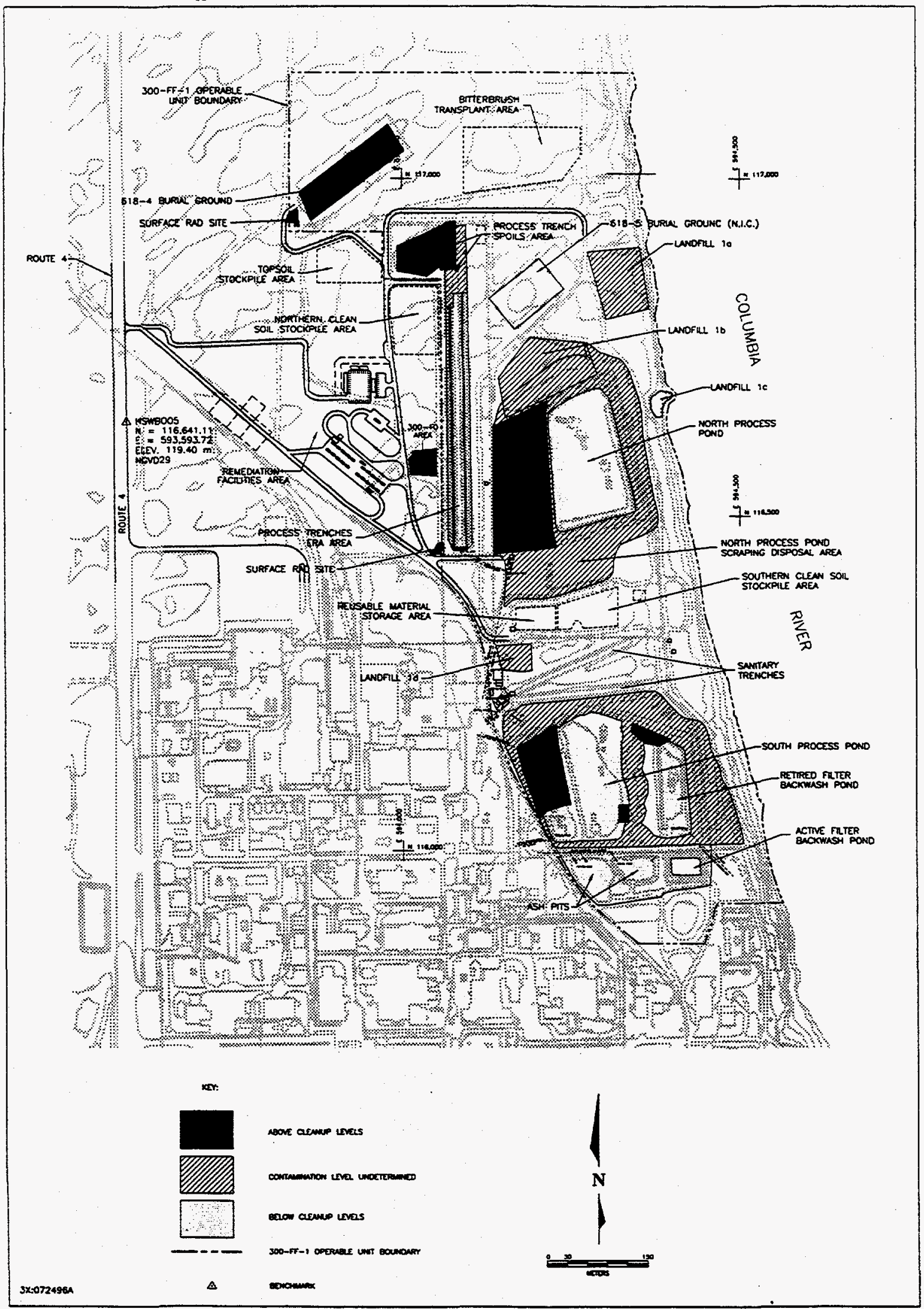


DOE/RL-96-70

Rev. 0

\subsubsection{General Design Elements Common to All Waste Sites}

\subsubsection{Site Utilities and Infrastructure.}

Functional Objective: Provide utilities, primarily electricity, telephone, water, and roadways to support remediation activities.

Approach:

- $\quad$ BHI will install utilities to the site for the RAS to tie into. Temporary utility plans prepared by the RAS will be submitted to BHI for approval.

- The RAS will provide support facilities for administration, testing, personnel and equipment decontamination, container handling, waste profiling, and all other remedial activities (BHI will install its own administrative facilities).

- Roadway will be constructed of gravel capable of supporting transport trucks and other heavy equipment using crushed rock conforming to Washington State Department of Transportation (DOT) standards. Minor roadside ditches will be required to control surface water runoff.

- Laydown and traffic areas will be located away from the Columbia River to the extent possible to avoid erosion and the disturbance of the more likely areas having cultural resources.

\subsubsection{Containment - Control Zone.}

Functional Objective: Limit the spread of contaminants during remediation.

Approach:

- Control zones will be established around logical groups of excavated areas. Supporting facilities (e.g., offices, shops) will be located outside of the control zone unless necessary to do otherwise. All personnel and materials (including waste containers and service equipment) will be surveyed and decontaminated as appropriate prior to exiting the control zone.

- Surface water will be controlled around the perimeter of the control zone to prevent runon and runoff of surface water.

- Excavation, loading, and equipment dedicated to transporting materials from the excavations will remain in the control zone. Service equipment may enter and leave after being surveyed to ensure the equipment is not contaminated. No other vehicles will be allowed in the control zone. 
DOE/RL-96-70

Rev. 0

- BHI will provide radiation control support and oversight in the field and will perform final radiation surveys for release of all equipment.

\subsubsection{Decontamination.}

Functional Objective: Prevent spread of contaminated material beyond limits of the remediation area.

Approach:

- Decontamination of equipment and personnel shall comply with the requirements of the Hanford Site Radiological Control Manual (HSRCM 1994).

- Decontamination equipment and methods will be approved by BHI. The decontamination facility will consist of (at a minimum) a washdown pad utilizing a flexible membrane liner to collect the decontamination fluids. All decontamination fluids will be collected in a holding tank. The decontamination fluid loadout facilities will be located outside of the control zone to avoid the need to decontaminate the tanker trucks. The decontamination system will use recirculation (reuse) of decontamination fluid as appropriate to minimize wastes.

- If below the purgewater acceptance criteria levels as defined in the Strategy for Handling and Disposing of Purgewater on the Hanford Site (WHC 1990), rinsate may be processed for reuse/recycle, used for dust suppression, or sampled, treated, and disposed. If the decontamination fluid is above purgewater acceptance criteria levels, the rinsate will be transferred to tanker trucks and transported to the 200 Area Effluent Treatment Facility or used as dust suppressant on contaminated waste sites.

- Personnel decontamination will be performed using industry standard decontamination trailers.

\subsubsection{Surface Water Control.}

Functional Objective: Prevent spread of contaminated material into clean areas via surface water runoff during remediation. Prevent uncontrolled inflow of water into excavations, decontamination areas, and other site facilities where it could disrupt operations.

Approach:

- Surface water will be directed using simple v-ditches and berms that can be readily constructed with available equipment. In contaminated areas, water will be routed to existing ponds or trenches for infiltration (similar to current site configuration), remediating these areas last. In noncontaminated areas, surface water will be routed away 
from contaminated areas using natural contours to the extent possible. Disturbance of native vegetation will be minimized.

- The RAS will prepare a surface water control plan for BHI approval prior to beginning remediation activities.

Key Assumptions: Soils have sufficient infiltration capacity so that surface water will infiltrate rapidly except during extreme weather conditions. If water is ponded longer than expected, work activities can be shifted to other areas.

\subsubsection{Excavation Slopes.}

Functional Objective: Minimize volume of excavated soils while providing safe working conditions.

Approach:

- The RAS is responsible for maintaining safe working conditions at all times. All trenching and shoring shall be in accordance with Occupational Safety and Health Administration (OSHA) regulations.

- The RAS shall submit an earthworks operation plan for BHI approval that will include plans for operation and placement of equipment, manpower, and materials.

Key Assumptions: $\quad$ Soils at the 300-FF-1 Operable Unit are expected to be stable under temporary excavation conditions at slope inclinations on the order of 1 horizontal to 1 vertical. If unexpected soil conditions are encountered during the excavation process, slopes can be adjusted in the field with limited impact to operations.

\subsubsection{Dust Control.}

Functional Objective: Minimize generation of contaminated dust so that both onsite and offsite exposure levels are kept to a practical minimum (within acceptable limits).

Approach:

- Allowable dust emissions, both onsite and offsite, will be established from applicable regulations (see Section 2.1.5).

- Water will be used for dust control at excavation sites. Dust studies for ERDF indicate that emissions are not detectable if the moisture content is greater than $2 \%$. Assuming 
DOE/RL-96-70

Rev. 0

soil conditions are somewhat similar at 300-FF-1, the generation of dust during implementation of the remedial action should not be an issue. The RAS may use benign stabilization mediums (e.g., $\mathrm{MgCl}_{2}$. lignosite) to stabilize roadways and laydown yards. BHI must be notified in writing of stabilization mediums to be used prior to application and sufficiently in advance to allow for a thorough review of the medium(s) to be used.

- Air monitoring will be required during excavation. The air monitoring plan should be included in the site-specific HASP.

Key Assumptions: If dust emissions are greater than expected, remedial operations may be modified to use other types of dust suppressants, increasing levels of personnel protection, prewetting excavation areas, or other innovative approaches.

\subsubsection{Worker Exposure and Safety.}

Functional Objective: Minimize worker risk from exposure and accidents during excavation (ALARA).

Approach:

- All elements of the design and implementation efforts must consider worker exposure and safety.

- The HASP will be prepared in accordance with Safety and Health Procedures (BHI-SH-02) for health and safety hazards recognition.

- Health and safety requirements are established from regulations and appropriate internal procedures and guidance, including the following:

- $\quad$ Radiation exposure limits will be established from DOE guidance and the Hanford Site Radiological Control Manual (HSRCM 1994).

- $\quad$ Protection against hazardous chemicals will be based on the information gathered during the RI/FS process and application of requirements in OSHA 1910.120.

- Construction safety will comply with OSHA regulations, DOE orders, and industry standards.

Key Assumptions: The excavation activities can be conducted using standard industry practices. 
DOE/RL-96-70

Rev. 0

\subsubsection{Extent of Soil Removal.}

Functional Objective: Remove soils and debris that are contaminated above cleanup levels. Minimize removal of clean soils. (An estimated volume of material to be excavated is provided in Appendix A.)

Approach:

- The RAS will provide all equipment for excavating and transporting wastes within the control zone. Waste containers and trucks for transporting wastes to ERDF will be provided by others. Sampling and analysis equipment will be provided by BHI. Details of sampling and analysis are presented in the SAP (Appendix C).

- Field-screening methods for uranium will be used to determine areas requiring excavation unless otherwise noted in Section 2.2.3. The depth of excavation will be dependent upon waste unit characteristics (see Section 2.2.3). Clean soil and topsoil will be stockpiled separately for use during reclamation.

- $\quad$ The RAS will be responsible for civil survey control for construction and as-built drawing development.

Key Assumptions: Identification of contaminated soils can be accomplished by field screening for uranium. Results of verification tests for all contaminants of concern will indicate the accuracy of this approach.

\subsubsection{Waste Minimization and Volume Reduction.}

Functional Objective: Minimize the volume of material that must be sent to ERDF. Avoid disposal of clean soils.

Approach:

- Temporary excavations and construction slopes should be kept as steep as feasible (without compromising safety).

- Waste minimization will be considered during development of the decontamination processes. Decontamination wastes will be kept to a minimum.

- Compaction/volume reduction of soil and debris at the ERDF will be performed as appropriate.

- Waste minimization will be considered when developing sample grid spacing that identifies sampling locations (optimization of grid spacing to minimize clean soil removal) as described in the SAP (Appendix C). 
DOE/RL-96-70

Rev. 0

\subsubsection{Materials Unacceptable to the Environmental Restoration Disposal Facility.}

Functional Objective: Identify and segregate materials that cannot be accepted at the ERDF (including land-disposal-restricted wastes). Avoid inadvertently shipping unacceptable materials to ERDF.

Approach:

- Incorporate (by reference) ERDF waste acceptance criteria into the SAP and waste management plan as appropriate. The scope of sampling required for ERDF disposal will be based on the acceptance criteria. If sampling results exceed allowable concentrations, additional samples may be taken to minimize waste volume of materials unacceptable for disposal at ERDF.

- The area to be excavated will be screened initially for uranium (using a sodium iodide detector) to determine areas/soils requiring excavation. Organic wastes will be screened using an organic vapor analyzer, gas chromatography, or other appropriate method (see $\mathrm{SAP}$, Appendix C). These data will be used to identify areas with contamination that exceed the ERDF waste acceptance criteria.

- Visual observation will be used during excavation to segregate soil, metallic objects, organic materials, construction debris, asbestos, and liquids (or liquid containers). A grizzly will be used to segregate the larger debris from the soils. Soils will be field screened for compliance with ERDF waste acceptance criteria as necessary prior to performing the excavations to the extent possible/practicable. This will minimize the number of containers stored in the transfer area awaiting analytical results.

Key Assumptions:

- The field-screening techniques used to determine the extent of soil removal, along with visual inspection, will be appropriate for determining whether ERDF waste acceptance criteria are met.

- Based on available RI data and a review of the ERDF waste acceptance criteria, the volume of unacceptable materials is not expected to be large. There is a greater likelihood of discovering unacceptable wastes in the burial grounds than in the process disposal sites.

\subsubsection{Site Restoration.}

Functional Objective: Remove all construction facilities, provide adequate drainage of remediated areas, and stabilize disturbed areas against soil erosion. 


\section{DOE/RL-96-70}

Rev. 0

Approach:

- Verify that all areas within the control zone are below cleanup levels.

- Decontaminate equipment as necessary for release from control zone.

- Remove all contaminated equipment that could not be decontaminated for use at other Hanford remedial sites or send to ERDF (if waste acceptance criteria are met). Remove all uncontaminated construction facilities, including offices, and utilities as appropriate. Certain facilities/site infrastructures may be left in place to support future remediation activities associated with the $300-F F-2$ Operable Unit.

- Backfill and regrade excavation areas to satisfy safety concerns and return the area to a natural rolling terrain. Avoid importing fill to the extent possible. The source of imported backfill will be approved by BHI. BHI will verify that the backfill is not contaminated prior to hauling. A clean soil stockpile area at the south end of the operable unit is planned to be used at this time. No others are expected to be needed.

- Minimize disturbance to native vegetation.

- Seed and reestablish vegetation in accordance with the mitigation action plan (see Section 3.4.4). The reclamation design life will be based on the timeframe required for natural revegetation/stabilization of the area.

Key Assumptions: $\quad$ Specific future industrial land uses are not defined in detail; therefore, a general approach to site reclamation is most appropriate at this time.

\subsubsection{Design Elements Specific to Individual Waste Sites}

2.2.3.1 Process Trenches. The Process Trenches were the focus of an expedited response action (ERA) performed in 1991. This action removed the contaminated sediment from the southern, active portion of the trenches and stockpiled it in the northern, inactive portion of the trenches. The remediation of the Process Trenches will therefore be separated into these two areas.

The remedial actions to be taken in the ERA portion of the trenches (area in which the contaminated sediments were removed) are summarized as follows.

The bird screens will be removed from the trenches. The bird screens were used to minimize birds accessing the sediments in the bottom of the trenches. These screens will be surveyed upon removal. If the screens can be released, they will be stockpiled and later used as backfill material in the Process Trenches in accordance with the requirements for restoration. 
The headworks and inlet pipes located on the southern end of the trenches will be surveyed to determine if they are contaminated. Initially, the concrete aprons at the outlets of the pipes will be removed, allowing the underlying soil to be surveyed to determine if it is above cleanup levels. If the surveys do not indicate the soil underlying the aprons is contaminated, verification samples will be taken as described in the SAP (Appendix C). Soil and other materials above cleanup levels will be loaded into transport containers for shipment to ERDF. Clean materials will be stockpiled as appropriate. These materials will be recycled/salvaged if possible; otherwise, they will be used as backfill in the Process Trenches.

If the inlet pipe is above cleanup levels, the first $15.24 \mathrm{~m}(50 \mathrm{ft})$ as measured from the outlet will be excavated, crushed, and loaded into transport containers for shipment of ERDF. The remaining end of the pipe will then be screened to determine if it is below cleanup levels. If the remaining end of the pipe is found to be above cleanup levels, the next $15.24 \mathrm{~m}(50 \mathrm{ft})$ shall be removed. This process shall be repeated until all contaminated pipe is removed or the boundary of the operable unit is reached.

In any area where headworks or pipe contaminated above cleanup levels has beenremoved, the adjacent soil shall be screened and removed as necessary. The remaining portions of the headworks will be demolished down to an elevation where at least $0.91 \mathrm{~m}$ ( $3 \mathrm{ft}$ ) of soil will be present above any remaining debris when site regrading is complete.

- The blockhouse to the east of the Process Trenches will also be demolished. The blockhouse will be screened to determine if it is contaminated above cleanup levels. Materials above cleanup levels will be loaded into transport containers and shipped to ERDF. Material below cleanup levels will be used as backfill in the Process Trenches.

The remedial actions to be taken in the portion of the trenches where the contaminated soils were stockpiled are summarized as follows.

- $\quad$ Areas Above Cleanup Levels: The sediments known to be above cleanup levels (e.g., those located in the western portion of the ERA spoils pile) will be removed down to the original topography. The sediments will be loaded into transport containers for disposal at ERDF.

- Areas of Undetermined Contamination: The stockpiled sediments with unknown contamination levels (e.g., those located in the eastern portion of the ERA spoils pile; area as delineated in Appendix C, Figure C-4) shall be remediated following the "Undetermined Contamination Level" procedure. Test pits (locations are described in Appendix C, Figure C-4) will be used to determine if the sediments located in the eastern portion of the spoils pile are above cleanup levels. The test pit soils will be screened for uranium from the surface to the bottom of the spoils pile to determine if these sediments are below cleanup levels. If the screening results indicate that the spoils 
sediments are below cleanup levels, a verification sample will be taken at the bottom, but within the spoils pile as described in Appendix C.

2.2.3.2 North Process Pond. The North Process Pond is divided into four areas for the purpose of remediation. The following describes each of these areas and the remedial actions to be taken.

- $\quad$ Areas Above Cleanup Levels: Areas known to be above cleanup levels in the North Process Pond are shown in Figure 2-3 and Appendix A. These areas will first be surveyed to provide waste profile information required for shipment and disposal at ERDF. In these areas, except for the flyash cell, a 0.9-m- (3-ft) thick layer of soil will be removed and loaded into transport containers for shipment to ERDF. The "Confirm as Clean" procedure will then be performed on the exposed subgrade in this area.

- Areas of Undetermined Contamination: Areas where the contamination level has not been determined are shown in Figure 2-3 and Appendix A. These areas shall be remediated as necessary under the "Undetermined Contamination Level" procedure. On the berms surrounding the North Process Pond and in the scrapings disposal area, trenches and/or test pits will be used to survey/sample the soils. The locations of these test pits and trenches are shown in the SAP (Appendix C).

- $\quad$ Areas Below Cleanup Levels: Areas that are thought to be below cleanup levels in the North Process Pond are shown in Figure 2-3 and Appendix A. The "Confirm as Clean" procedure will be applied to these areas. After this process has been completed, these areas may be used for temporary storage of soil below cleanup levels.

- Tank and Weir Structure: The tank and weir structure in the southwest corner of the pond will be field screened to determine if they can be released. The tank and weir structure will be removed and disposed of in accordance with the process described in the "Miscellaneous Debris Removal" process described in Section 2.2.3.9.

2.2.3.3 South Process Pond and Retired Filter Backwash Pond. The South Process Pond and Retired Filter Backwash Pond are divided into three areas for the purposes of remediation. Each of these areas and the remedial actions to be taken are described as follows.

- $\quad$ Areas Above Cleanup Levels: Areas known to be above cleanup levels in the South Process Pond are shown in Figure 2-3 and Appendix A. These areas will first be surveyed to provide waste profile information required for shipment and disposal at ERDF. In these areas a $0.91-\mathrm{m}-(3-\mathrm{ft})$ thick layer of soil will be removed and loaded into transport containers for shipment to ERDF. The "Confirm as Clean" procedure will then be performed on the exposed subgrade in this area.

- $\quad$ Areas of Undetermined Contamination: Areas where the contamination level has not been determined are shown in Figure 2-3 and Appendix A. These areas will be remediated as necessary under the "Undetermined Contamination Level" procedure. On 
DOE/RL-96-70

Rev. 0

the berms surrounding the South Process Pond, trenches and/or test pits will be used to survey/sample the soils. The locations of these test pits and trenches are shown in the SAP (Appendix C).

Areas Below Cleanup Levels: Areas that are thought to be below cleanup levels in the South Process Pond are shown in Figure 2-3 and Appendix A. The "Confirm as Clean" procedure will be applied to these areas. After this process has been completed, these areas may be used for temporary storage of soil below cleanup levels.

2.2.3.4 Sanitary Sewer System. The headworks and piping associated with the sanitary sewer system will be demolished to a level at least $0.91 \mathrm{~m} \mathrm{(} 3 \mathrm{ft}$ ) below final grade (after site restoration is complete). Debris removed will be disposed of in accordance with the "Miscellaneous Debris Removal" process described in Section 2.2.3.9. These structures will not require screening.

2.2.3.5 Ash Pits. The "Confirm as Clean" procedure will be performed on the Ash Pits. Test pits shall be excavated down to the original ground surface, estimated to have a maximum depth of about $4 \mathrm{~m}$. The locations of the test pits are shown in the SAP (Appendix C).

2.2.3.6 Landfills. Landfills $1 \mathrm{a}, 1 \mathrm{~b}$, and $1 \mathrm{~d}$ shall be remediated as described below. Landfill $1 \mathrm{c}$ requires no further action to be taken.

The clean soil present over the landfill areas (if present) will be removed in $30.48-\mathrm{cm}-(1-\mathrm{ft}$ ) thick layers. This material will be placed into the nearest clean soil stockpile area. If debris is observed on the surface of the exposed subgrade, the overlying soil will be considered contaminated above cleanup levels and will be retained at the landfill until screened, sampled, and dispositioned for treatment and/or disposal.

The debris and associated soils will be screened (as described in the SAP, Appendix C) to determine if they are above cleanup levels and satisfy the ERDF waste acceptance criteria. A 30.48-cm- (1-ft) thick lift (horizontal or vertical) of material will then be excavated and passed through a $150-\mathrm{mm}$ (6-in.) grizzly screen located within the landfill footprint. The materials will be dispositioned in one of the following ways.

- Soils above cleanup levels and acceptable to ERDF and all debris will be loaded into transport containers for shipment to ERDF.

- If above cleanup levels but not acceptable to ERDF, the material will be stockpiled within the footprint of the landfill pending final disposition. Unacceptable material stockpiles may require relocation during landfill remediation so that all underlying debris, fill material, and subgrade contaminated above cleanup levels can be removed. Unacceptable materials will be dispositioned in sufficient time so that the restoration activities are not impacted. 
Rev. 0

- Soils below cleanup levels will be stockpiled in one of the clean soil storage areas for use as backfill.

2.2.3.7 618-4 Burial Ground. Remediation of the 618-4 Burial Ground will be performed as described in Section 2.2.3.6 with the following exception regarding the handling of cover materials.

Approximately 20 to 25 specimens of large antelope bitterbrush presently located on the surface of the burial ground will be transplanted to an area located east of the landfill. The upper $150 \mathrm{~mm}$ ( $6 \mathrm{in}$.) of topsoil will then be removed from the landfill and stockpiled in the nearest clean topsoil stockpile area. Large vegetation shall be chipped and mixed into the topsoil. The next $460 \mathrm{~mm}(1.5 \mathrm{ft})$ of cover material shall then be removed and moved to the nearest clean soil stockpile area.

2.2.3.8 Surface Radiation Zones. Posted surface radiation zones are shown in Figure 2-3 and include the 300-10 Area. A 30.48-cm- (1-ft) thick lift of surface material will be removed and loaded into transport containers for disposal at ERDF [a 1.2-m (4-ft) lift will be used at the 300-10 Area]. The subgrade will be sampled and remediated as necessary under the "Confirm as Clean" procedure.

2.2.3.9 Miscellaneous Debris. Miscellaneous debris known to exist on the site includes concrete vault covers, pipes, and various metal objects. Other types of debris may also be encountered. All man-made debris located on the surface will be removed. Field screening will be performed to determine if the debris can be released under the guidance of HSRCM (1994). If the debris cannot be released, it will be loaded into a transport container for shipment to ERDF. If the debris can be released and is reusable, it will be stockpiled in the reusable material storage area. If the material is not reusable, it will be stockpiled and used as backfill during site restoration.

There are also approximately 44 barrels and boxes of investigation-derived waste presently stored south of the North Process Pond. These barrels and boxes will be loaded into transport containers for shipment to ERDF. 
DOE/RL-96-70

Rev. 0 
DOE/RL-96-70

Rev. 0

\subsection{REMEDIAL ACTION APPROACH AND MANAGEMENT}

\subsection{REMEDIAL ACTION PROCESS DESCRIPTION}

The ROD for the 300-FF-1 Operable Unit directs the DOE to perform remediation activities at selected waste sites located within the operable unit. These activities include selective excavation of soils/debris contaminated above cleanup levels from process waste units, which were primarily used for disposal of liquid waste streams originating from the fuel fabrication processes in the 300 Area. Excavation and disposal of the contaminated contents of the 618-4 Burial Ground is also required by the ROD (EPA 1996).

The remedial action implementation process will use the RDR/RAWP to govern implementation of the remediation process. The RDRRAWP is being prepared concurrently with the remedial design that will provide the remediation subcontractor with design specifications necessary for preparing the final remediation designs and schedules in accordance with the ROD.

The remedial design is being performed by a subcontractor experienced in this type of remedial action. The RDS is researching existing information (e.g., RI results, utility layouts) to prepare/design the general site layout, typical roadways, decontamination areas, waste transfer stations, contaminated volume estimates, and other supporting facilities.

The remedial design specifications/information will be provided to the RAS to complete the designs and remedial action procedures. Providing the general remedial design information to the potential RAS will result in better, more accurate bids by allowing optimization of the remedial actions using its specific equipment, materials, and remediation experience. Transportation of the excavated contaminated materials from the site to the ERDF is the responsibility of the ERDF.

BHI personnel will be overseeing the RDS and RAS to ensure that the remedial actions taken are appropriate and will meet the required RAOs. BHI will also perform the site sampling activities, provide radiation control personnel and equipment, and oversee site safety.

The remedial action can be divided into six separate subactions/activities: Pre-Excavation, Excavation, Material Handling and Transportation, Soil Characterization and Analysis, Decontamination, and Waste Profiling. A description of each of these elements is provided in the following subsections.

\subsubsection{Pre-Excavation}

A RAS will be contracted to perform the excavation activities required by the ROD. The RAS will prepare necessary design documents/procedures and other required submittals for BHI approval. Specific designs include the necessary support facilities, utilities, equipment 
decontamination stations, frisking station, and detailed site plans/drawings. All designs must meet the requirements/specifications identified in Section 2.0.

Before initiation of excavation activities, the RAS will mobilize necessary equipment and prepare the site in accordance with approved designs/plans. Site preparation activities include establishing the control zones around contaminated areas requiring excavation; establishing roadways; constructing waste profiling facilities, frisking stations (used to survey equipment and waste boxes from the site), haul roads, decontamination facilities, support facilities (e.g., offices, equipment maintenance areas, laydown yards); and installing utilities to the site (e.g., power, water), which will be completed by $\mathrm{BHI}$ personnel or others. $\mathrm{BHI}$ radiation control and sampling personnel will perform site surveys to delineate the clean versus contaminated areas.

The RAS must demonstrate that all personnel who will be performing work onsite have completed the required training and meet the necessary medical requirements identified in the HASP.

Prior to granting a Notice to Proceed for excavation, a readiness review will be completed to demonstrate that the RAS and its personnel, procedures, and equipment are ready to begin.

\subsubsection{Excavation}

Excavation activities will commence with field surveys of the contaminated areas. The field surveys will consist of both civil surveying and radiological/chemical surveys. The civil surveys shall be used by the RAS to develop base site maps. The radiological/chemical surveys in conjunction with RI data will delineate contaminated versus noncontaminated areas and provide waste designation information as needed. Each waste site will be subdivided into one of three subunits based on the field surveys and RI data: contaminated area, noncontaminated area, and inconclusive areas.

RI data will be used to minimize the amount of radiological/chemical surveys needed. Areas with known contamination will be excavated to a predetermined depth with minimal surveys. Excavation activities in inconclusive areas will require field screening lift by lift. Areas thought to be below cleanup levels will be surveyed and sampled.

Once the areas requiring excavation within a working area have been identified and the fieldscreening activities have been completed, excavation activities will commence. The excavated materials will be removed using standard equipment for both shallow and deep excavations as appropriate. The contaminated materials will be placed into transfer containers for shipment to ERDF. The noncontaminated soils will be stockpiled for site recontouring once all contaminated materials have been removed.

The excavations within the process waste units will occur in lifts. Once the first lift has been removed, the area will be resurveyed to again determine the extent of contamination. This process will continue until field analytical techniques indicate the area is clean. Verification 
samples will then be taken to determine if the remedial action goals/objective have been met. If the results indicate the area is "clean," it will be released from the control area as appropriate. If the results indicate contamination above cleanup levels remains, the excavation activities will continue as appropriate.

Excavation of the burial ground will begin by performing a field-screening survey over the surface followed by the transplanting of the bitterbrush vegetation east of the burial ground and mulching or chipping the remaining vegetation that will be removed with the cover soils. The cover soils will be stockpiled separately from the remaining overburden/debris and screened to confirm that they are below the established cleanup levels. Once the surface cover has been removed, the contents of the burial ground will be excavated. Waste designation samples will be taken as necessary. The contaminated soils and debris will be cut or compacted as necessary and placed into transfer boxes for shipment to ERDF. If the materials do not meet the ERDF acceptance criteria, they will be placed in a storage area within the area of contamination pending treatment and/or identification of an alternate disposal method or waivers are granted.

\subsubsection{Material Handling and Transportation}

Material handling and transportation activities will be performed by the RAS inside the controlled areas. The RAS will load the contaminated materials into the shipping containers (provided by the ERDF) and move the loaded containers to the frisking station. At the frisking station, the loaded shipping containers will be surveyed to verify that the outside is free of contamination. If clean, the containers will be moved to the transfer station where the containers will be moved to a clean haul truck for shipment to ERDF. Transportation to the disposal facility will be provided by ERDF. ERDF is responsible to ensure that all DOT shipping requirements, including use of appropriate shipping containers and labeling, are met.

A waste storage area will be established at the remedial action site to store loaded transfer boxes pending shipment to ERDF. This is necessary when wastes are excavated at a rate faster than that scheduled and ERDF becomes backlogged with waste shipments.

Wastes that exceed the ERDF waste acceptance criteria will be placed on storage pads within the controlled area pending treatment and/or identification of appropriate disposal methods or a waiver is granted.

\subsubsection{Soil/Debris Characterization and Analysis}

Soil/debris characterization and analysis (field screening) will be performed to provide process control for excavation activities, provide waste identification information for shipping and disposal, and provide necessary information for demonstrating that the RAOs have been met. Additional sampling may be performed to demonstrate any offsite backfill material, if required, is clean prior to delivery. All sampling and analysis activities in support of the remedial action will be performed in accordance with the requirements of the SAP (Appendix C). 


\section{DOE/RL-96-70}

Rev. 0

Additional data from past sampling efforts may also be used in performing the remedial action. These data are provided in the RI/FS reports for the 300-FF-1 Operable Unit (DOE-RL 1993a, 1993b, 1994, 1995b).

\subsubsection{Decontamination}

If contamination is found on the outside of the shipping containers at the frisking station, the container will be routed through the decontamination station for cleaning. Upon being decontaminated, the shipping container will return to the frisking station to ensure the outside is free of smearable contamination. The decontamination station may also be used to remove contamination from equipment and materials upon completion of the remedial actions.

The decontamination station will be designed, constructed, and operated by the RAS per the requirements/specification in Section 2.2.2.3.

\subsubsection{Waste Profile Station}

The waste profile station, located past the frisking and decontamination stations, will be used to prepare the waste shipping and disposal request forms necessary for disposing of the excavated materials at ERDF. The RAS will provide BHI with container identification number, date of excavation, type of material, excavated materials point of origin, and container gross weight. BHI will use this information in addition to any sampling data obtained to prepare the shipping and disposal forms in accordance with DOT and ERDF requirements.

\subsection{PROJECT SCHEDULE}

Project schedules are developed in accordance with BHI procedures ERC-PC-01, Baseline and Funds Management System, at several different levels consistent with the project work breakdown structure. The work breakdown structure-based schedules promote complete and consistent compliance with DOE Order 4700.1, "Project Management System," and cost and schedule control systems criteria. Large-scale (multi-year) projects encompassing multiple smaller projects (i.e., each subelement identified in Section 3.1 can itself be considered a single project, while the entire project is to remediate all waste sites in the 300-FF-1 Operable Unit) are generally planned and scheduled using a phased approach. Near-term $(<1 \mathrm{yr})$ work is usually planned and scheduled at a detailed activity level using logic ties to establish and maintain a true critical-path schedule. Logic-driven, critical-path schedules, commonly referred to as the "critical-path method," are used to manage and control the daily progress of the work and provide early warning of problem areas. Forecast planning and scheduling (1 to 2 years) can be performed at the task-package level, and long-range planning and scheduling ( $>2$ years) is performed at the work-package or cost-account levels.

The schedule for performing remedial actions identified in the 300-FF-1 Operable Unit is being planned at the work-package level, i.e., the activities will take more than 2 years to complete. 
The planning elements at this level of detail include remedial design, procurement, remedial actions, and site closures. It is currently estimated that these tasks will be completed in approximately 4 years, with the site closure occurring in the second quarter of fiscal year 2000 .

The following subsections describe the major activities planned for each of the major schedule elements. The schedule for performing each of these elements is provided in Figure 3-1.

\subsubsection{Remedial Design/Remedial Action Work Plan}

The remedial design element and its subelements are responsible for all design work, project plans, remediation cost estimating, drawings, and specifications required to perform the remedial actions. A remedial design dictating the requirements/specification for performing the remedial action is being developed concurrently with this remedial design report.

The remedial design developed the design requirements discussed herein, provides contaminated volume estimates and the assumptions used, provides conceptual site layout information/ drawings, and also contains the SAP and mitigation action plan. Each of these documents is described further in Section 3.4. A cost estimate for performing the remedial action is being prepared as part of the remedial design process. Additional plans, described below, will be prepared by the RAS.

The remedial design will provide information necessary for contracting the RAS who will be responsible for, in addition to performing the remedial action, providing detailed information with regards to how it will perform/implement the remedial action within the design specifications provided. This includes submittals for how (1) site restoration will be completed, (2) environmental compliance will be ensured, (3) wastes will be managed, and (4) materials will be handled and transported onsite. This method allows the RAS to have the flexibility to optimize the remedial action process while ensuring the RAOs are not sacrificed. The RAS will also provide revised cost estimates for implementing the remedial action. The schedule provides 2 months for development and approval of the final design documentation.

\subsubsection{Procurement}

Procurement and procurement subelements are responsible for soliciting qualified ' subcontractors, preparing requests for proposal, awarding the subcontract(s), coordinating submittals, negotiating change orders, and receiving and controlling subcontractor requests for payments. The request for proposal documents are being prepared in parallel with the remedial design discussed in Section 3.2.1. Procurement of the RAS was initiated on May 17, 1996, by issuing a request for expression of interest memorandum. This memorandum requested that potential bidders identify themselves. The RAS is scheduled to be awarded by the end of February 1997. Support for this procurement will continue on a level-of-effort basis throughout the duration of the remedial action. 


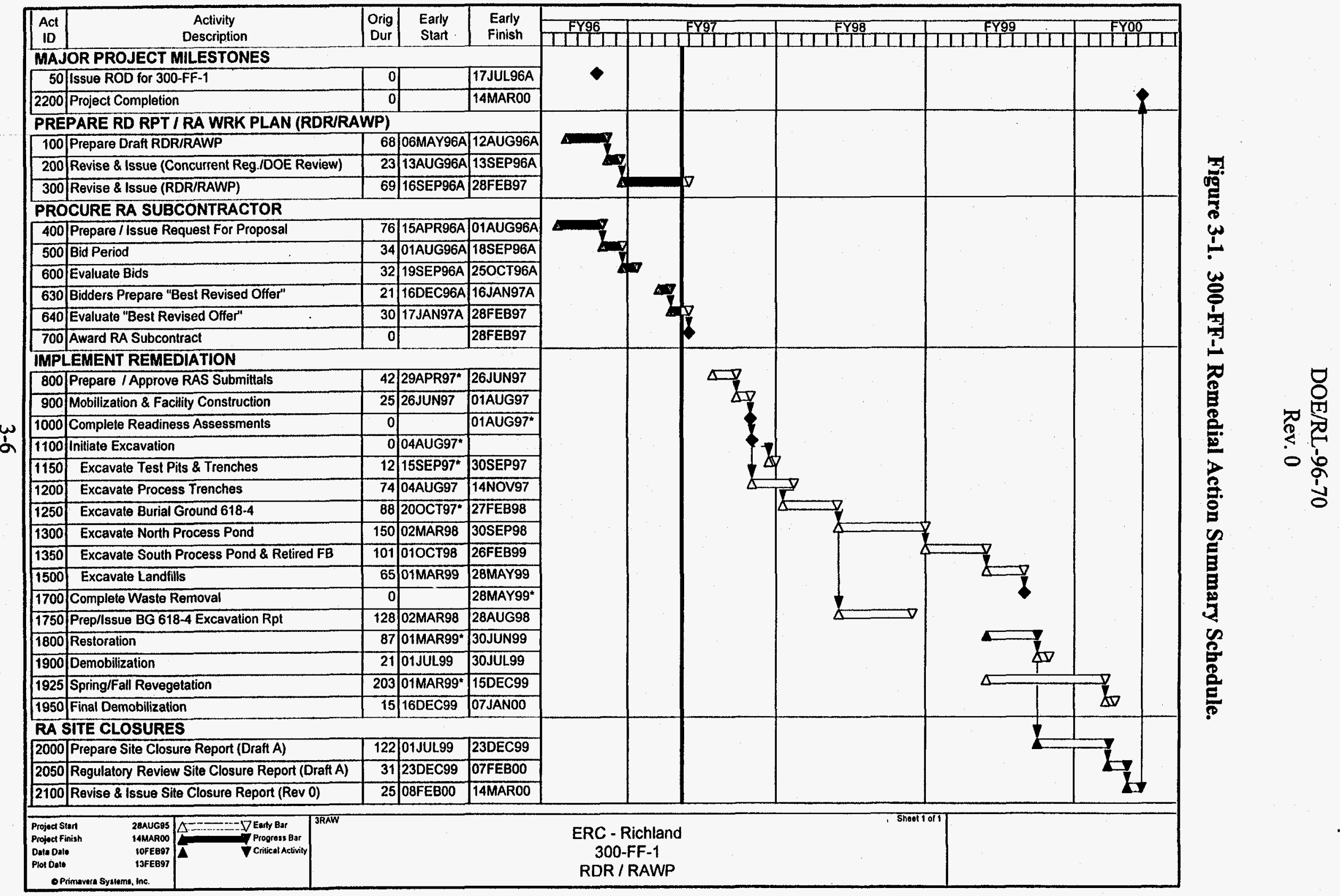


DOE/RL-96-70

Rev. 0

\subsubsection{Remedial Actions}

The remedial action subelements are those tasks and activities specific to implementation of approved remedial designs and project plans. Specific tasks include preparation of the RAS's field implementing procedures, equipment mobilization and construction of support facilities, completing a readiness review/evaluation, excavation of contaminated waste sites, site restoration, and demobilization. The schedule for performing the remedial actions will be dictated by the RAS design package. The minimum scheduling requirements the RAS has to meet are to initiate remediation of the Process Trenches first and complete excavation of the 618-4 Burial Ground by February 28, 1998. The schedule for initiation of remediation activities at the remaining waste sites will be developed by the RAS based on the excavation completion date of May 28, 1999. The RAS will also be given minimum productivity rates (e.g., a minimum production rate of 23,000 metric tons per quarter but not to exceed 787.5 metric tons per day). It is currently estimated that the remedial actions for the entire operable unit will take approximately 2 years to complete, including site backfilling, recontouring, and revegetation.

\subsubsection{Site Closures}

Site closure is separated from the remedial action activities because of the effort required to manage and evaluate site contaminant data and prepare closure reports. Site closure includes, but is not limited to, data evaluation, data interpretation, preparation of closeout documentation, and updating Hanford Site environmental sites database and mapping system.

Closure of the Process Trenches must be performed in accordance with the approved modified closure/postclosure plan (DOE-RL 1995a). This involves preparation and submittal of a certification of closure prepared and issued by an independent licensed professional engineer. This certification must be submitted within 60 days of closure (completion of remedial action) of the Process Trenches. It is estimated that the site closure process will take approximately 6 months to complete.

\subsection{PROJECT TEAM}

"Project team," in the strictest sense, means all individuals working to complete a particular project. According to this definition, numerous members of the "project team" are required to complete the remediation project at the 300-FF-1 Operable Unit. For the purpose of this report, only the major members of the team will be discussed. These members are the ERC (BHI and its preselected subcontractors); the DOE; and the regulatory agencies, EPA and Ecology.

\subsubsection{Regulatory Agencies}

The regulatory agencies for the 300-FF-1 Operable Unit remediation activities are the EPA, the lead regulatory agency, and Ecology. (NOTE: Ecology is the lead regulatory agency for the Process Trenches because they are managed under the authority of RCRA.) The lead regulatory 
agency is responsible for overseeing the activities and ensuring that all applicable requirements are met. The EPA may, and does, request support from Ecology as necessary.

\subsubsection{U.S. Department of Energy}

The DOE is the government agency responsible for performing the remedial action at the 300-FF-1 Operable Unit. The DOE has assigned project managers to each major area and task involved with remediation activities. The DOE project manager is responsible for the development of project scope, budget, and schedules. The project manager also oversees project elements and resources including quality assurance, communications, risk/safety, contracts, and assigned project personnel. The project manager is also responsible for the day-to-day communication with the regulatory agencies.

\subsubsection{Environmental Restoration Contractor}

The ERC team consists of BHI; its preselected subcontractors, CH2M HILL Hanford, Inc., IT Hanford, Inc., and Thermo Hanford, Inc; and the RAS. Under the direction of the manager of remedial action projects, a project manager (task lead) is assigned consistent with the project management assignments of DOE to promote single point-of-contact management philosophy. Each ERC project manager is responsible for performing the specific workscope assigned by the DOE project manager. Specific responsibilities include assembling the project team, which consists of all required disciplines necessary to accomplish the remedial action in a safe, efficient, and compliant manner. Figure 3-2 presents a typical field organizational structure followed by $\mathrm{BHI}$ when performing a remedial action such as this.

\subsection{PLANNING DOCUMENTATION}

Planning documentation to implement remedial actions includes the preparation of field documents required to implement the work to be performed. Documents are prepared by project staff and are reviewed by ERC functional groups. Documents considered to develop the scope of work performed require the review and concurrences of $\mathrm{DOE}$ and the regulatory agencies as appropriate.

\subsubsection{Field Procedures/Permits}

Field procedures are internal BHI or RAS documents used to provide direction to site workers responsible for execution of the field work. The procedures ensure that the objectives of the required action are met in a safe and efficient manner. These procedures depict the progression of field work, personnel control requirements, and radiological posting requirements. Field procedures required for implementation of the 300-FF-1 remedial action include radiological work permits; excavation permits; and operational procedures describing how excavated materials will be handled, how equipment/material decontamination will be performed, how 
DOE/RL-96-70

Rev. 0

Figure 3-2. 300-FF-1 Remedial Action Field Organizational Chart.

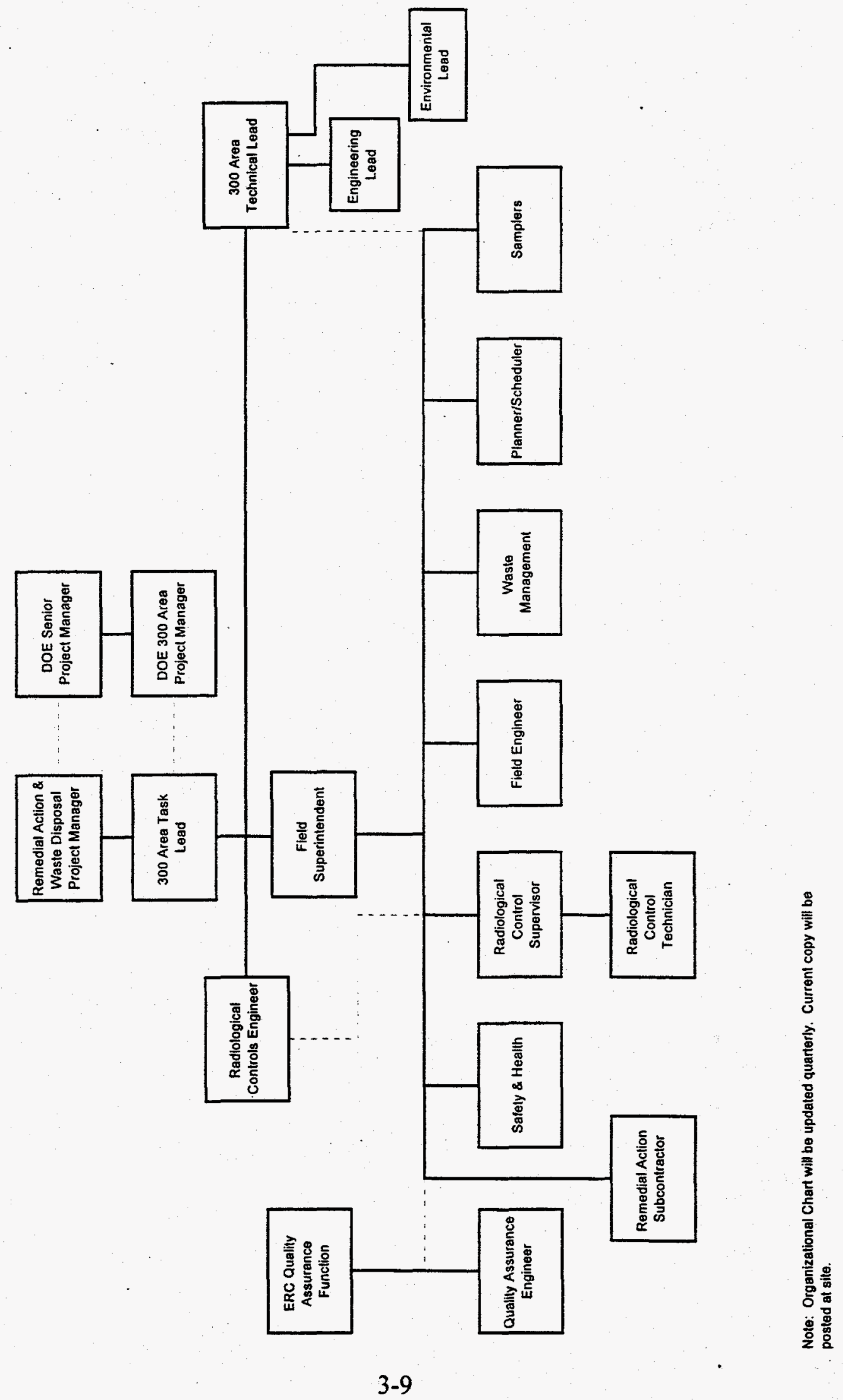


waste designation/shipping requirements will be met, and how contaminated materials/ equipment will be stored.

\subsubsection{Sampling and Analysis Plan}

The SAP is used to provide direction to field samplers during implementation of the field remedial action and summarize the data management process. The SAP is developed to meet specific data quality objectives established to ensure compliance with the remedial action goals and objectives established for the remedial action. The SAP for 300-FF-1 includes fieldscreening samples for process/excavation control and verification sampling to determine if the area has been remediated to below established cleanup standards. The SAP must be reviewed and approved by both DOE and the regulatory agencies. The SAP is included as Appendix C of this document.

\subsubsection{Health and Safety Plan}

The HASP was prepared in conjunction with the activity hazards' classification. This plan identifies those hazards associated with the activities to be performed. The HASP also provides measures to be taken to minimize the potential for undue injury/exposures resulting from performing these actions. The site-specific HASP will be prepared by the project health and safety officer and will be reviewed by all project staff and ERC functional organizations. The site superintendent must ensure compliance with the HASP at all times. All project field staff must understand the HASP. The HASP is prepared and revised in accordance with the Safety and Health Procedures (BHI-SH-02). This procedure manual ensures that the remedial action activities are performed in accordance with 29 CFR 1910.120, "Hazardous Waste Operations and Emergency Response."

\subsubsection{Mitigation Action Plan}

The mitigation action plan provides guidance to the design and field staff to ensure that natural and cultural resources are protected during field activities. The plan covers avoidance and minimization steps to minimize impacts to both natural and cultural resources resulting from implementation of the remedial action. Native American concerns are also identified and incorporated within this plan. Natural resource issues are coordinated with the Natural Resource Trustees; cultural resource issues are coordinated with the Native American Tribes. The mitigation action plan is prepared by the ERC project team and will be provided to the DOE, the Native American Tribes, and the trustees for their review and comment. The mitigation action plan will also recommend future revegetation goals for the remediated and disturbed areas. Locally derived native species will be used for revegetation if possible.

\subsubsection{Environmental Compliance Plan}

The 300-FF-1 environmental compliance plan that summarizes the requirements for handling and minimizing waste during remediation of the $300-\mathrm{FF}-1$ Operable Unit will be prepared by the 
DOE/RL-96-70

Rev. 0

RAS. The plan covers both waste minimization steps to minimize the amount of noncontaminated soils/debris being disposed at ERDF and the minimization of wastes generated during the remedial action including decontamination fluids and other solid wastes. The environmental compliance plan also addresses air quality compliance, water quality protection, environmental reporting, hazardous material management, and protection of natural and cultural resources.

\subsubsection{Earthwork Plan}

An earthwork plan that details the methods, equipment, and scheduling of activities associated with earthwork will be prepared by the RAS. The plan will include as a minimum radiological control layout, traffic control, excavation methods, sideslopes, trenching and shoring, access ramps, number and size of work crews, drainage and erosion control, dust control, and spill prevention.

\subsubsection{Excavated Material Handling Plan}

An excavated material handling plan that details the methods, equipment, and scheduling activities will be prepared by the RAS. The plan will include the following elements: waste minimization, packaging and disposal procedures, container liner handling procedures, decontamination methods, methods to transfer containers into "clean" zones, container staging procedures, container tracking systems and weighing methods, below cleanup level soils and "other" materials storage procedures, and container design for materials that do not meet ERDF waste acceptance criteria.

\subsubsection{Public Involvement Plan}

A public involvement plan has been prepared to ensure information is provided to the public during the remedial design and the remedial action processes. This plan is presented in Appendix D of this document.

\subsection{REMEDIAL ACTION CHANGE MANAGEMENT}

Implementation of remedial actions may require changes to the requirements set forth in the ROD when unexpected wastes streams and/or site conditions are encountered. A remedial action change management process is therefore necessary to minimize the impacts of these unforeseen circumstances. Three types of changes are provided for that affect compliance with the requirements in the ROD: (1) a nonsignificant or minor change, (2) a significant change to a component of the remedy, and (3) fundamental changes to the overall remedy.

A nonsignificant or minor change falls within the normal scope of changes occurring during the remedial design and remedial action processes. These minor changes should be documented in the appropriate post-decision project file. Nonsignificant changes shall not impact the 
requirements of the ROD or the functional requirement described in Section 2.0. Examples of nonsignificant changes include, but are not limited to, the following:

- The addition of waste sites that are adjacent to and/or within the sites requiring remediation as identified in the ROD

- Modifications to the remedial action schedule that do not impact agreed-upon milestones.

It may be determined that a significant change to the selected remedy as described in the ROD is necessary. Significant changes are defined as changes that significantly modify the scope, performance, or cost of a component of the remedy as presented in the ROD. All significant changes will be addressed in an explanation of significant difference. An example outline for an explanation of significant differences can be found in Exhibit 8-3 of Guidance on Preparing Superfund Decision Documents (EPA 1989). Examples of significant changes include, but are not limited to, the following:

- A $50 \%$ increase in remedial action costs or contaminant volumes

- A delay in the point in time when the remedial action or objectives are met

- The addition of waste sites for remediation in a manner that is consistent with the scope and role of action as described in the ROD.

A fundamental change is one that does not meet the requirements set forth in the ROD or incorporates remedial activities not defined in the scope of the ROD. In few cases are there fundamental changes to a ROD. Should the situation arise, the ROD must be revised and approved accordingly. Examples of significant changes that fundamentally alter the remedy occur when:

- Waste remains in place above cleanup objectives due to cultural resources

- A final land use is defined that is not compatible with that assumed by the ROD

- An ARAR variance is requested for land disposal restriction treatment.

The ERC project manager is responsible for tracking all changes and obtaining appropriate reviews by ERC staff. The project manager will discuss the changes with DOE. The DOE will then discuss the required changes with the regulatory agencies. It is the role of the lead regulatory agency to determine the significance of the change. Appropriate documentation will follow based on the type of change.

In addition to the change process described above, the change processes required by the 300 Area Process Trenches Modified Closure/Postclosure Plan (DOE-RL 1995a) and the Hanford SiteWide Dangerous Waste Permit must also be followed. 
DOE/RL-96-70

Rev. 0

\subsection{GOALS ATTAINMENT}

This section describes the approach for verifying attainment of the remedial action goals identified in the ROD. The general approach for verifying attainment of remedial action goals involves the following steps:

- Identify waste units for cleanup verification

- Identify the remedial action goals listed in Section 2.0 that apply to a particular waste unit

- Define decision rules to test verification sampling and analysis results

- Calculate summary statistics on verification sampling results for waste unit

- Verify attainment of proposed radionuclide soil cleanup standard

- Verify attainment of MTCA cleanup standards

- Verify protection of groundwater and the Columbia River.

\subsubsection{Identify Units for Cleanup Verification}

Each waste site is divided into units for purposes of collecting verification samples. Summary statistics [i.e., arithmetic (or geometric mean depending on contaminant distribution) and $95 \%$ upper confidence limit (UCL)] are calculated for the verification samples for each particular unit. Verification sampling and analysis data will be tested with the decision rules on a unit-by-unit basis.

\subsubsection{Identify the Appropriate Remedial Action Goal(s)}

The goal or goals that apply to a waste site must be identified in order to determine if the remedial actions at that site have attained the RAOs described in the ROD. A review of Section 2.0 will provide all information necessary to identify the appropriate remedial action goals. 
DOE/RL-96-70

Rev. 0

\subsubsection{Define Decision Rules}

From the goals identified above, decision rules are defined that will be used to test verification sampling and analysis data as described in the SAP (Appendix C). These decision rules are as follows:

- $\quad$ MTCA standards are achieved under the following conditions (WAC 173-340. 740[7][e]):

- $\quad 95 \%$ UCL on the arithmetic or geometric mean from verification samples collected is less than the cleanup standard for each contaminant of concern

- $\quad$ No single sample concentration is greater than two times the cleanup standard

- Less than $10 \%$ of the sample concentrations exceed the cleanup standards.

- $\quad$ EPA proposed radionuclide soil cleanup standard is achieved under the following condition:

- The dose from the $95 \%$ UCL on the arithmetic or geometric mean for each contaminant of potential concern from verification samples collected from the sides and bottom of the excavation is less than $15 \mathrm{mrem} / \mathrm{yr}$. The dose is calculated, using the RESRAD model, assuming exposure through inhalation and external gamma exposure pathways using industrial exposure assumptions (specific assumptions for dose calculations are presented in Appendix B).

\subsubsection{Calculate Summary Statistics}

The summary statistics needed for each unit are arithmetic and geometric mean, standard deviation, one-sided $95 \% \mathrm{UCL}$, and total number of samples collected from the unit. The number of samples with concentrations exceeding the MTCA cleanup standard and two times the MTCA cleanup standard are required from the sampling and analytical data.

\subsubsection{Verify Attainment of Proposed Radionuclide Soil Cleanup Standards}

Determining when the remedial action has achieved the cleanup level ( $15 \mathrm{mrem} / \mathrm{yr})$ involves converting radionuclide concentrations (in $\mathrm{pCi} / \mathrm{g}$ ) in soil into dose rates (in $\mathrm{mrem} / \mathrm{yr}$ ) using a dose assessment model. Use of a model requires an exposure scenario that specifies (1) a hypothetical receptor (i.e., a resident, worker, or recreational user of a site), (2) pathways of exposure from radionuclides in soil to the receptor, and (3) assumption and parameters for estimating exposures and doses to the receptor from radionuclides in soil. 


\subsubsection{Verify Attainment of MTCA Cleanup Standards}

Verifying attainment of MTCA cleanup standards involves comparison of the appropriate summary statistics with the remedial action goal(s) presented in Table 2-1 and using the decision rules for MTCA standards presented in Section 3.6.3.

\subsubsection{Verify Attainment of Groundwater and Columbia River Remedial Action Goals}

Verifying attainment of groundwater and Columbia River remedial action goals will be demonstrated by verifying attainment of the proposed radionuclide soil cleanup standards and MTCA cleanup standards. Additionally, the results of site closeout/verification soils data will be modeled using the RESRAD code to verify that new model results are equal to or lower than the concentration and time plots from the original analysis.

\subsection{CERCLA CLOSEOUT DOCUMENTATION}

A CERCLA closeout report will be prepared once attainment of remedial action goals has been verified. The closeout report will provide the needed documentation for closeout of remedial actions performed at the 300-FF-1 waste sites (excluding the Process Trenches, which will be closed under RCRA authority) and support the eventual delisting of the operable unit from the NPL. Closeout reports will be prepared for the entire 300-FF-1 Operable Unit using an outline similar to the following:

\begin{tabular}{|c|c|c|}
\hline \multicolumn{2}{|r|}{ Section } & Contents \\
\hline & Introduction & $\begin{array}{l}\text { - General statement indicating that the remedial action had been } \\
\text { successfully performed }\end{array}$ \\
\hline & Summary of Site Conditions & $\begin{array}{ll}\text { - } & \text { Site background } \\
\text { - } & \text { Early actions performed } \\
\text { - } & \text { Remedial investigation/feasibility study results } \\
\text { - } & \text { Design criteria } \\
\text { - } & \text { Cleanup activities performed } \\
\text { - } & \text { Community involvement activities performed }\end{array}$ \\
\hline & $\begin{array}{l}\text { Demonstration of Cleanup } \\
\text { Activity } Q A / Q C\end{array}$ & $\begin{array}{l}\text { - Quality assurance/quality control protocol followed } \\
\text { - Sampling and analysis protocol followed } \\
\text { - Results of onsite inspections }\end{array}$ \\
\hline & Monitoring Results & $\begin{array}{l}\text { - Sufficient data to demonstrate cleanup levels specified in the ROD or } \\
\text { Action Memoranda are achieved and implemented and remedies are } \\
\text { performing to design specifications } \\
\text { Monitoring required at no-action sites after the ROD is signed should be } \\
\text { briefly documented in the Closeout Report }\end{array}$ \\
\hline
\end{tabular}


DOE/RL-96-70

Rev. 0

\begin{tabular}{|c|c|}
\hline Section & Contents \\
\hline $\begin{array}{l}\text { V. Summary of Operation And } \\
\text { Maintenance }\end{array}$ & $\begin{array}{l}\text { - Assurance that operation and maintenance (O\&M) plans are in place and } \\
\text { are sufficient to maintain the protectiveness of the remedy } \\
\text { - Assurance that all necessary institutional controls are in place } \\
\text { - Assurance that O\&M activities specified for the site will be performed by } \\
\text { the State or the responsible party }\end{array}$ \\
\hline VI. Protectiveness & $\begin{array}{l}\text { - Assurance that the implemented remedy (or no-action decision) achieves } \\
\text { the degree of cleanup or protection specified in the ROD(s) for all } \\
\text { pathways of exposure and that no further Superfund response is needed } \\
\text { to protect human health and the environment } \\
\text { Assurance that all areas of concern described in the NPL listing have } \\
\text { been adequately addressed }\end{array}$ \\
\hline VII. Five-Year Review & $\begin{array}{l}\text { - Statement explaining whether a 5-year review is appropriate and, if so, } \\
\text { the type of review (statutory or policy) and the schedule for the review }\end{array}$ \\
\hline VIII. Bibliography & Complete citations of all relevant reports \\
\hline
\end{tabular}

\subsection{RCRA CLOSURE OF THE PROCESS TRENCHES}

Because the Process Trenches are managed as a RCRA treatment, storage, or disposal unit, they must be closed in accordance with the RCRA regulation. As part of the RCRA Part $B$ permitting process, a modified closure/postclosure plan (DOE-RL 1995a) was prepared that governs the process by which the trenches will be closed. Closure of the trenches requires a certification of closure be prepared and submitted to Ecology within 60 days of completing the remedial actions at the site. The certification of closure will be prepared and submitted to Ecology by an independent Washington State registered professional engineer.

\subsection{SITE RELEASE}

The DOE will continue to manage the land in the 300-FF-1 Operable Unit as long as necessary to support remedial actions and other site missions. The time frame depends on many different parameters and will be documented in DOE's comprehensive land-use (a 50-year time frame) and strategic (5-year time frame) planning efforts, which are updated as needed. The 300-FF-1 ROD assumes the future use of the 300 Area will be for industrial purposes. Access to the property will be controlled in the near term by periodic patrols by Hanford Site personnel (as long as it is under DOE jurisdiction). The property will also be controlled through deed restrictions if DOE sells or leases the property to others. 
DOE/RL-96-70

Rev. 0

\subsection{REFERENCES}

BHI-QA-01, ERC Quality Program, Bechtel Hanford, Inc., Richland, Washington.

BHI-QA-02, Quality Program Procedures, Bechtel Hanford, Inc., Richland, Washington.

BHI-SH-02, Safety and Health Procedures, 4 vols., Bechtel Hanford, Inc., Richland, Washington.

BHI, 1996, Environmental Restoration Disposal Facility Waste Acceptance Criteria, BHI-00139, Rev. 2, Bechtel Hanford, Inc., Richland, Washington.

DOE-RL, 1993a, Phase I Remedial Investigation Report for the 300-FF-1 Operable Unit, DOE/RL-92-43, Rev. 0, U.S. Department of Energy, Richland Operations Office, Richland, Washington.

DOE-RL, 1993b, Phase I and II Feasibility Study Report for the 300-FF-I Operable Unit, DOE/RL-92-46, Rev. 0, U.S. Department of Energy, Richland Operations Office, Richland, Washington.

DOE-RL, 1994, Phase II Remedial Investigation Report for the 300-FF-I Operable Unit: Physical Separation of Soils Treatability Study, DOE/RL-93-96, Rev. 0, U.S. Department of Energy, Richland Operations Office, Richland, Washington.

DOE-RL, 1995a, 300 Area Process Trenches Modified Closure/Postclosure Plan, DOE/RL-93-73, Rev. 1, U.S. Department of Energy, Richland Operations Office, Richland, Washington.

DOE-RL, 1995b, Phase III Feasibility Study Report for the 300-FF-1 Operable Unit, DOE/RL-94-49, Rev. 0, U.S. Department of Energy, Richland Operations Office, Richland, Washington.

DOE-RL, 1995c, Proposed Plan for the 300-FF-1 and 300-FF-5 Operable.Units, DOE/RL-95-88, Rev. 0, U.S. Department of Energy, Richland Operations Office, Richland, Washington.

Drummond, M. E., 1992, The Future for Hanford: Uses and Cleanup - A Final Report of the Hanford Future Site Uses Working Group, Hanford Future Site Uses Working, Group, Richland, Washington.

Ecology, EPA, and DOE, 1990, Hanford Federal Facility Agreement and Consent Order, 2 vols., as amended, Washington State Department of Ecology, U.S. Environmental Protection Agency, and U.S. Department of Energy, Olympia, Washington. 
DOE/RL-96-70

Rev. 0

EPA, 1989, Guidance on Preparing Superfund Decision Documents, EPA/540/2-89/057, U.S. Environmental Protection Agency, Washington, D.C.

EPA, 1996, Record of Decision for the U.S. Department of Energy Hanford 300-FF-1 and 300-FF-5 Operable Units, U.S. Environmental Protection Agency, Washington, D.C.

ERC-PC-01, Baseline and Funds Management System, Bechtel Hanford, Inc., Richland, Washington.

HSRCM, 1994, Hanford Site Radiological Control Manual, HSRCM-1, Rev. 2, HSRCM Project, U.S. Department of Energy, Richland, Washington.

WHC, 1990, Strategy for Handling and Disposing of Purgewater on the Hanford Site, WHC-MR-0039, Rev. 0, Westinghouse Hanford Company, Richland, Washington.

WHC, 1996, Groundwater Monitoring Plan for the [RCRA] 300 Area Process Trenches, WHC-SD-EN-AP-185, Rev. 0, Westinghouse Hanford Company, Richland, Washington. 
DOE/RL-96-70

Rev. 0

APPENDIX A

WASTE SITE INFORMATION 
DOE/RL-96-70

Rev. 0

A-2 
DOE/RL-96-70

Rev. 0

300-FF-1 Waste Site Locations

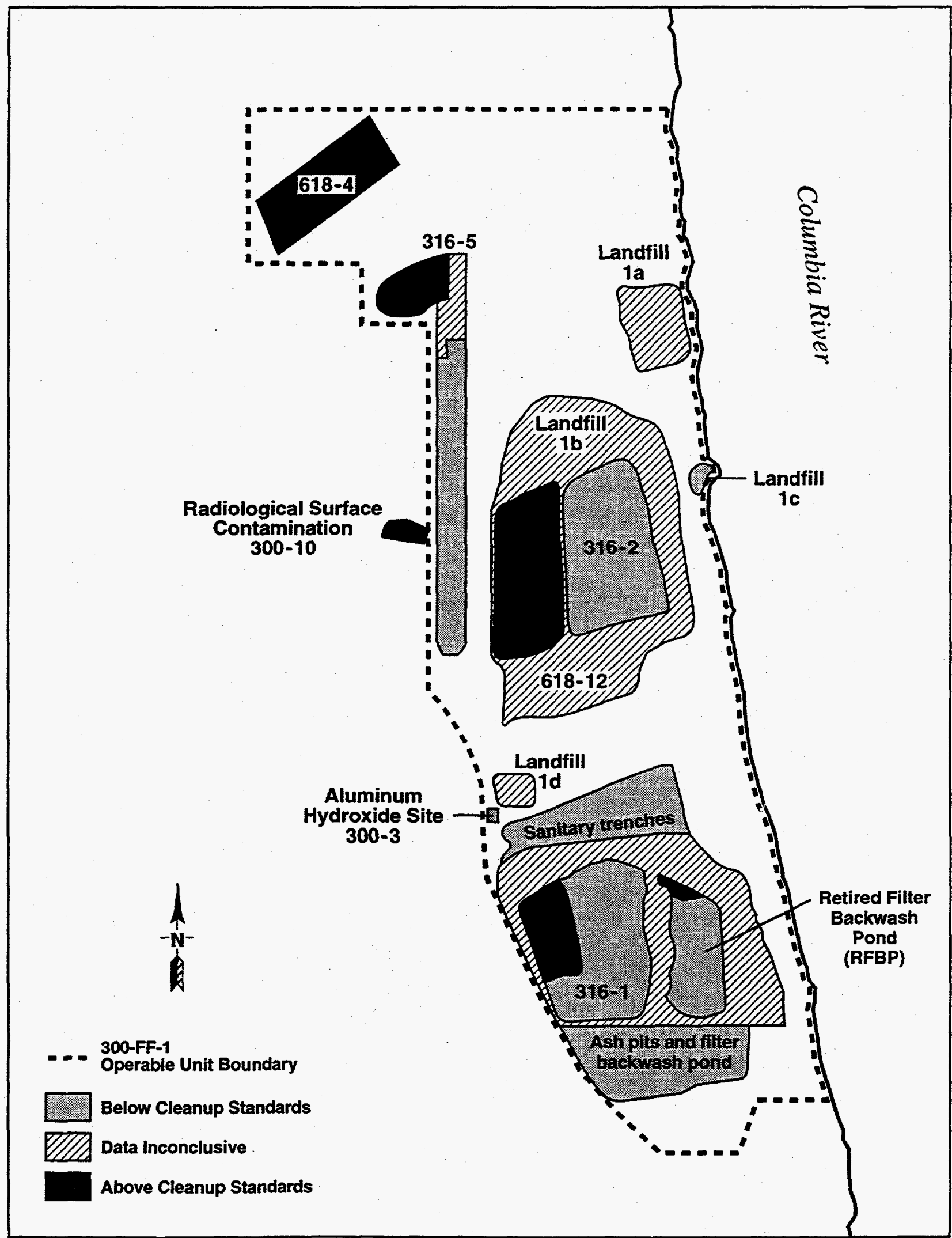


DOE/RL-96-70

Rev. 0

\section{NORTH PROCESS POND SITE GROUPING}

Grouping includes the North Process Pond (316-2), the North Pond Scraping Area (618-12), and Landfill $1 \mathrm{~b}$.

\section{Waste Site Background Summary}

The North Process Pond was built and activated in 1949, following a dike failure at the South Process Pond. Both ponds operated until 1975, when the units were replaced by the 316-5 Process Trenches. The pond was originally a single, unlined infiltration basin that was later subdivided into six small settling ponds and one large infiltration basin. When the sludge in the bottom of the pond slowed the percolation rate, the basins were dredged. The sludge was deposited on the pond dikes and placed in the North Pond Scraping Area, located immediately south of the pond, or put in Landfill $1 \mathrm{~b}$, located just north of the pond. The pond received process waste from the 300 Area laboratories, fuel fabrication facilities, and the 300 Area Powerhouse, although from 1953 to 1963, laboratory effluents were diverted to the 307 Trenches via the 307 Retention Basin. The 307 Trenches were backfilled in 1963. Retention basin waste below discharge limits was released to the process ponds until 1975, when they were replaced by the 316-5 Process Trenches.

- Identified Contaminants of Concern: Uranium

- $\quad$ Assumed Excavation Depth (in Areas Above Cleanup Standards): $0.91 \mathrm{~m}$ (3 ft)

- $\quad$ Estimated Soil Volume Above Cleanup Standards: 53,804 loose cubic meters (lcm) 
DOE/RL-96-70

Rev. 0

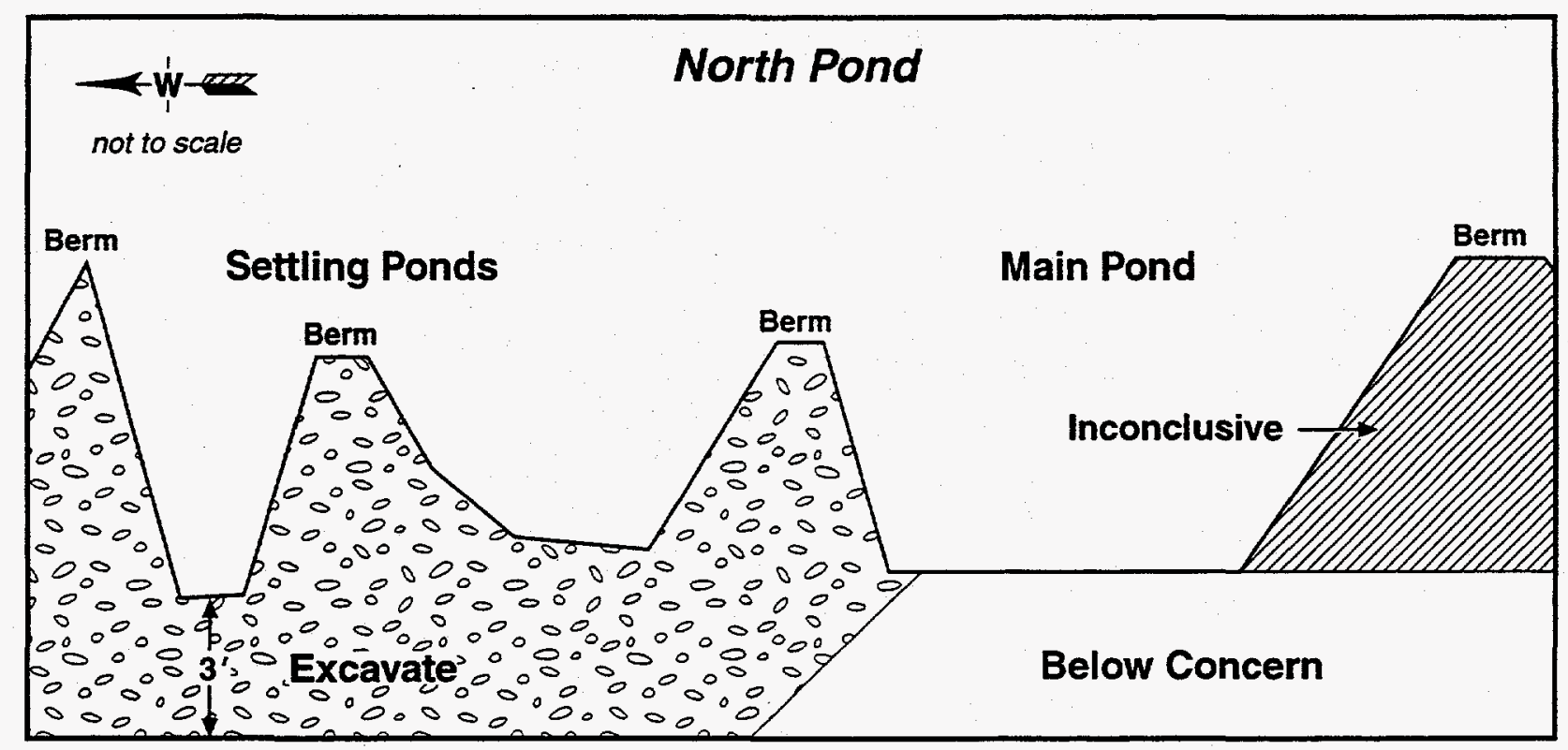

See Remedial Action Work Plan for slope details

300-FF-1

Operable Unit Boundary

Delow Cleanup Standards

EZT Data Inconclusive

Above Cleanup Standards

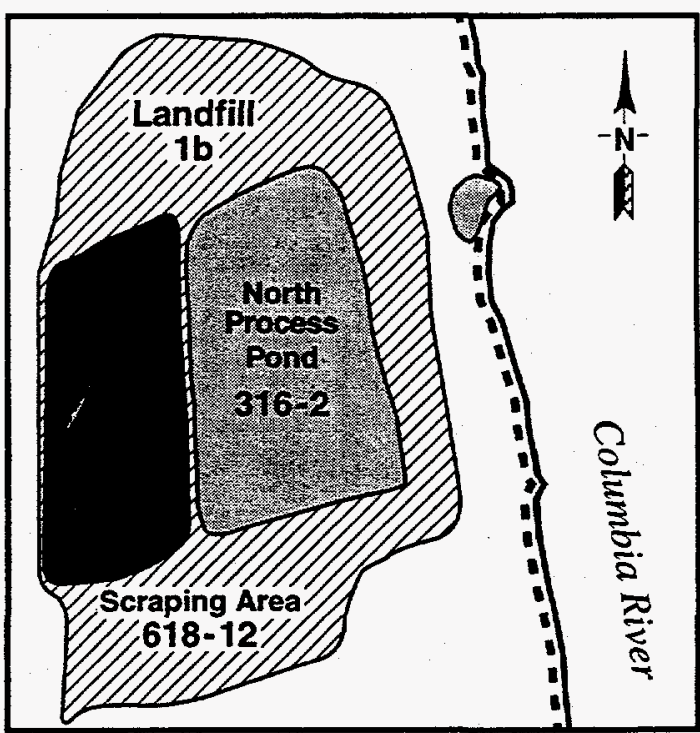

E9605072.6 
DOE/RL-96-70

Rev. 0

\section{SOUTH PROCESS POND SITE GROUPING}

Grouping includes the South Process Ponds (316-1), the pond separation berm, and the Retired Filter Backwash Pond.

\section{Waste Site Background Summary}

The South Process Pond is an unlined infiltration basin constructed in 1943. It was the first 300 Area process liquid disposal facility. It was originally a single, large infiltration pond with the inlet on the southwest corner. Later, dikes were added and the inlet was moved to the northwest corner. The water then flowed through three settling ponds before entering the infiltration pond. The pond was periodically dredged of sediments to improve the infiltration rate. The sediments were mostly large quantities of sodium aluminate and aluminum hydroxide. The spoils were deposited on the pond dikes or removed elsewhere to be used as backfill material. The pond received process waste from early 300 Area laboratories, fuel fabrication facilities, and the 300 Area Powerhouse. From 1953 to 1963, new laboratory facility effluents above discharge limits were diverted to the 307 Trenches via the 307 Retention Basin. The 307 Trenches were backfilled in 1963. Retention basin waste below discharge limits was directed to the process ponds until 1975. When the process ponds were retired in 1975, the eastern lobe of the South Process Pond was used by the 300 Area water treatment plant as a filter backwash pond. It was used for this purpose until 1987.

- Identified Contaminants of Concern: Uranium, cobalt-60

- $\quad$ Assumed Excavation Depth (in Areas Above Cleanup Standards): $0.91 \mathrm{~m}$ (3 ft)

- Estimated Soil Volume Above Cleanup Standards: $24,461 \mathrm{lcm}$ 


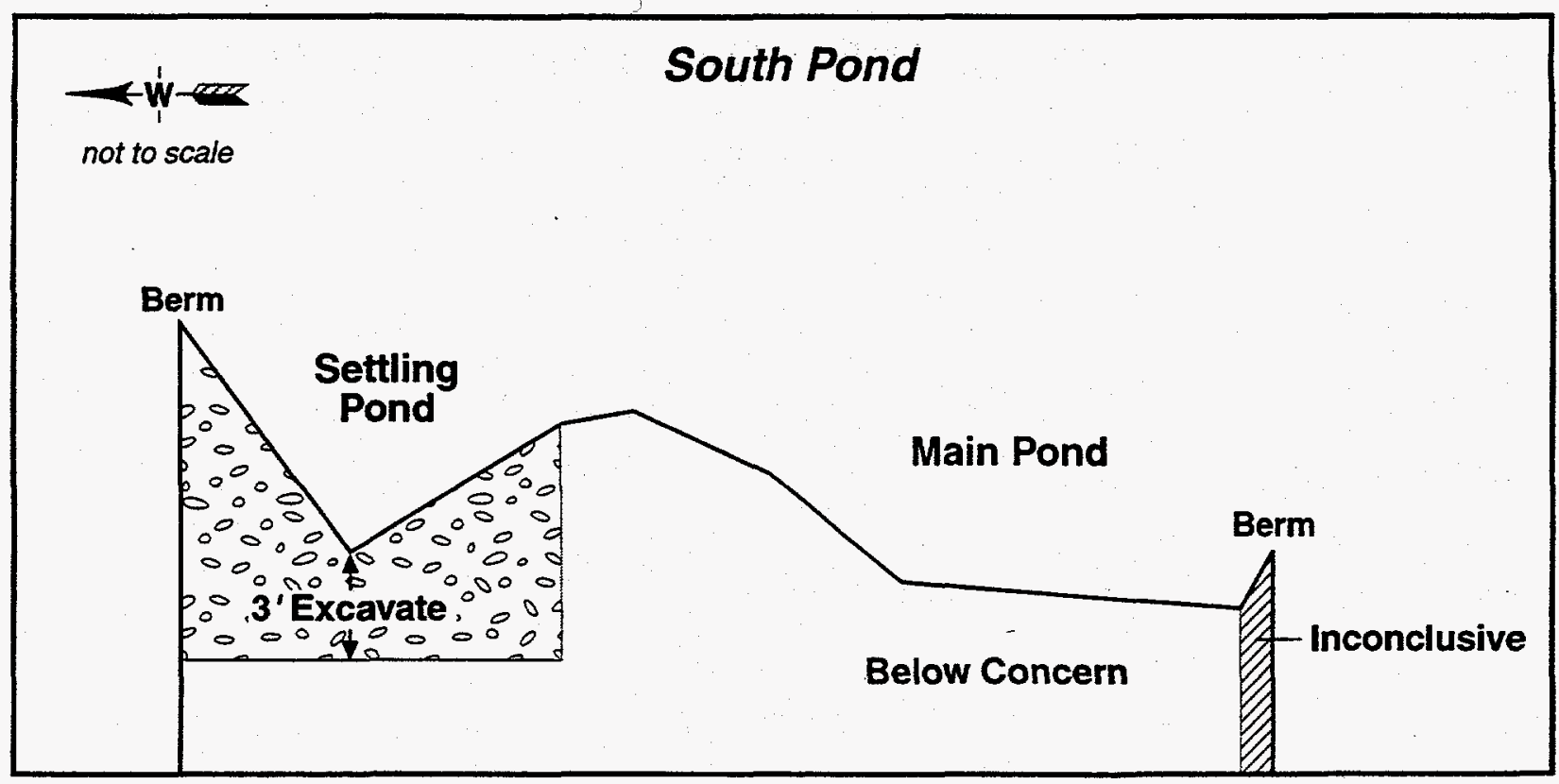

See Remedial Action Work Plan for slope details

300-FF-1

Operable Unit Boundary

Below Cleanup Standards

Data Inconclusive

Above Cleanup Standards

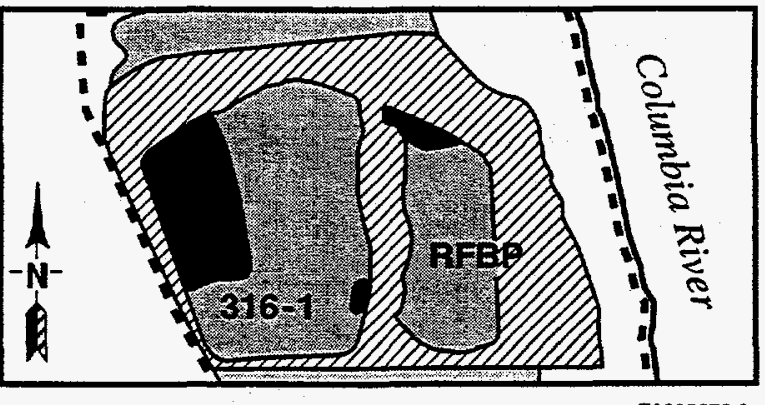

E9605072.8 
DOE/RL-96-70

Rev. 0

\section{PROCESS TRENCHES SITE GROUPING}

This grouping includes two process trenches and the spoils pile area at the north end of the trenches.

\section{Waste Site Background Summary}

The 300 Area Process Trenches (316-5) became active in 1975, replacing the North and South Process Pond system. The Process Trenches consist of two parallel, unlined trenches. The trenches are $1,535 \mathrm{ft}$ long, $10 \mathrm{ft}$ wide, and $12 \mathrm{ft}$ deep, spaced $50 \mathrm{ft}$ apart. The trenches received 300 Area Process effluent from the uranium fuel fabrication facilities and 300 Area laboratories. Laboratory process waste was first monitored at the 307 Retention Basin. Retention basin waste below discharge limits was released to the trenches. Waste above discharge limits was diverted to the 340 Facility. In 1991, an expedited response action removed contaminated soil and sludge from the sides and bottom of the trenches. The spoils were removed to the northwest corner of the west trench and covered with plastic and aggregate. This action allowed the trenches to continue to operate without flushing residual contaminants into the groundwater. Discharge to the Process Trenches was discontinued in December 1994. 300 Area effluents were then directed to the 300 Area Treated Effluent Disposal Facility.

- Identified Contaminants of Concern: Uranium, cobalt-60, arsenic, polychlorinated biphenyls, chrysene, thallium, benzo(a)pyrene

- Assumed Excavation Depth (in Areas Above Cleanup Standards): 3.65 to $5.49 \mathrm{~m}$ (12 to $18 \mathrm{ft}$ )

- $\quad$ Estimated Soil Volume Above Cleanup Standards: $14,556 \mathrm{lcm}$ 
DOE/RL-96-70

Rev. 0

\section{Process Trenches}

not to scale

\section{Spoils Pile}

Trenches (North end)

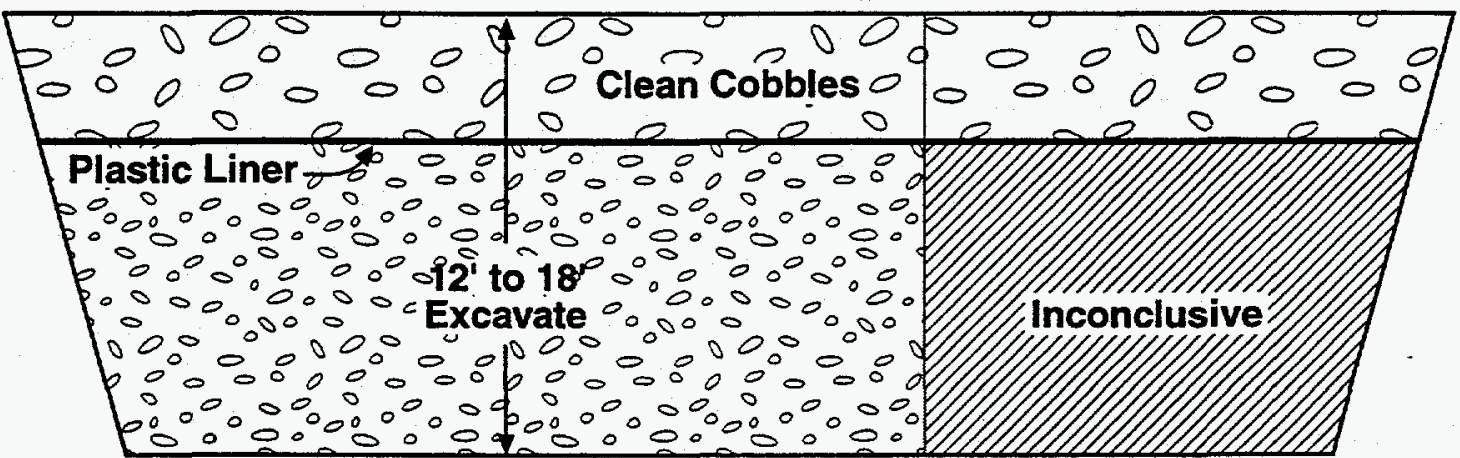

See Remedial Action Work Plan for slope details

$300-F F-1$

Operable Unit Boundary

Below Cleanup Standards

Data Inconclusive

Above Cleanup Standards

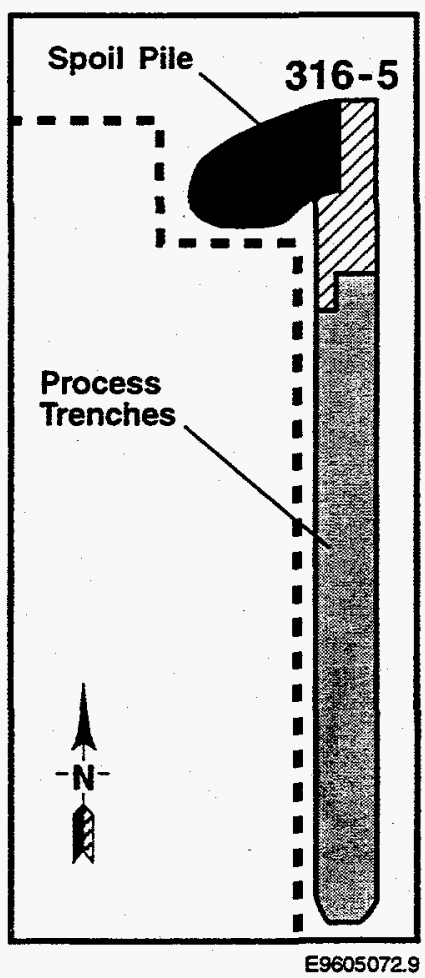


DOE/RL-96-70

Rev. 0

\section{8-4 BURIAL GROUND}

\section{Waste Site Background Summary}

The 618-4 Burial Ground is located northwest of the 316-5 Process Trenches. It is a single pit measuring $105 \mathrm{ft}$ by $525 \mathrm{ft}$. The burial ground was in use between 1955 and 1961. It received unknown quantities of miscellaneous uranium-contaminated material. Ground-penetrating radar scans were done in 1987 and 1991. Characterization test pits were dug in 1992. The pits revealed radiologically contaminated pipe, scrap metal, barrels, aluminum shavings, salt-bath precipitate, and miscellaneous debris. Tetrachloroethene, 1,2-dichloroethene, and trichloroethene were detected in eight soil gas samples.

- Identified Contaminants of Concern: Uranium

- $\quad$ Assumed Excavation Depth (in Areas Above Cleanup Standards): $4.57 \mathrm{~m}$ (15 ft)

- Estimated Soil Volume Above Cleanup Standards: 9,306 lcm 
DOE/RL-96-70

Rev. 0

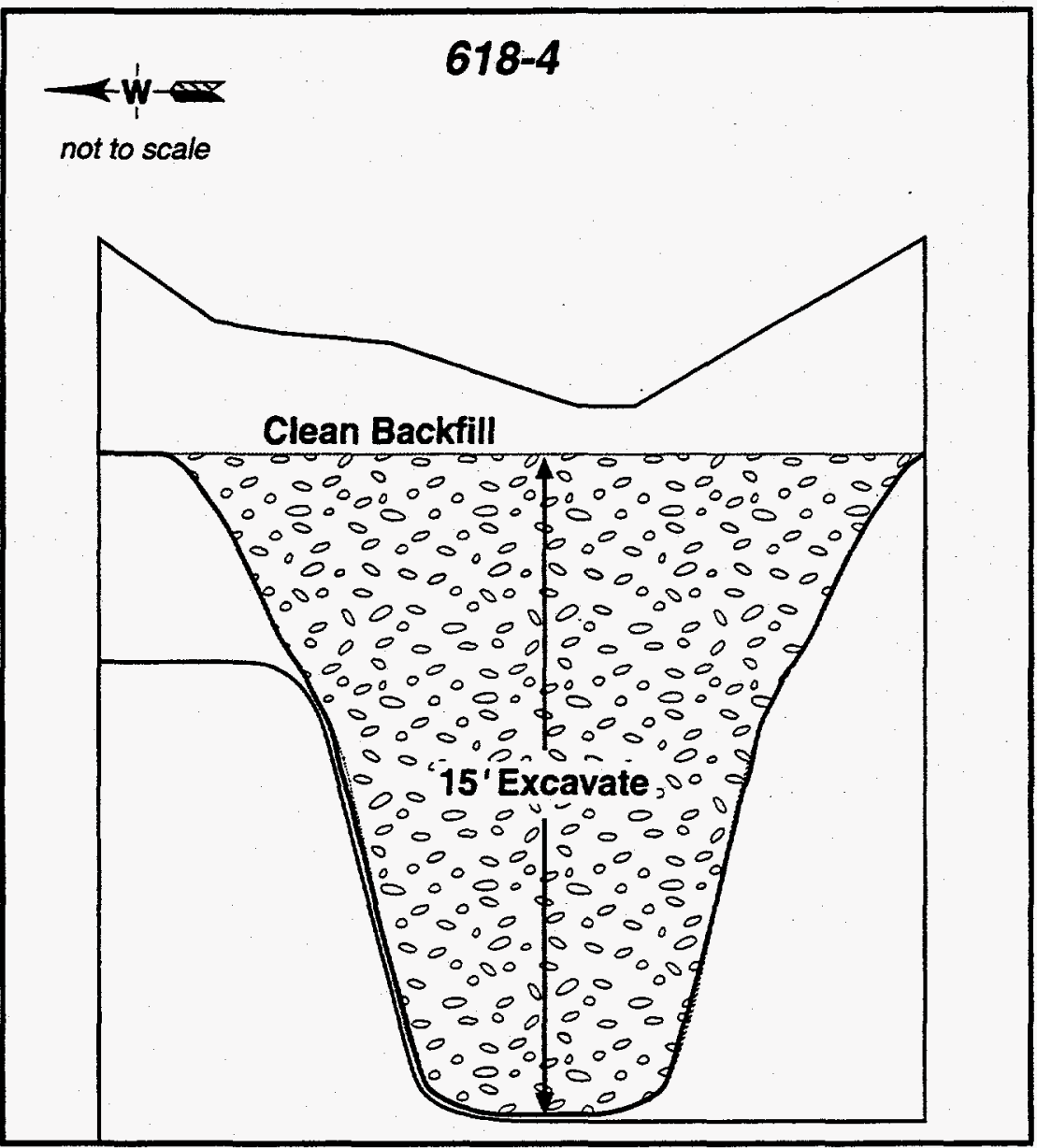

See Remedial Action Work Plan for slope details

300-FF-1

Operable Unit Boundary

Below Cleanup Standards

Data Inconclusive

Above Cleanup Standards

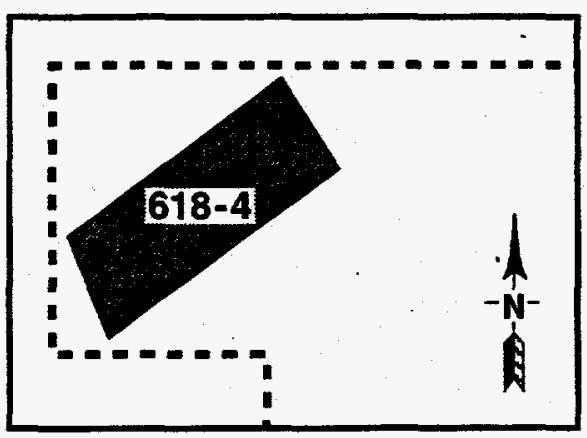

E9605072.7 
DOE/RL-96-70

Rev. 0

\section{LANDFILL GROUPING}

This grouping includes Landfills $1 \mathrm{a}, 1 \mathrm{c}$, and $1 \mathrm{~d}$.

\section{Waste Site Background Summary}

Small landfill areas were used by 300 Area operations from its early activities in the 1940 's until waste regulations became more precise in the 1970 's. Historical aerial photographs indicate the locations of these sites. There is little or no documentation of their contents. Geophysical surveys and surface radiological surveys were done as part of the 300-FF-1 remedial investigation.

Available information indicates that Landfill la was active in 1948 and is expected to contain miscellaneous, low-level radiologically contaminated solid waste.

Landfill $1 \mathrm{c}$ contained some radiologically contaminated surface debris. The debris was removed. Additional radiological surveys and ground-penetrating radar surveys indicate no further action is necessary at Landfill $1 c$.

Aerial photographs indicate that Landfill 1d (628-4) was a burn pit, in use in 1962. It appears to have been used alternately with the $618-5$ Burial Ground burning activities. It is unclear when it ceased to be active, but a 1974 aerial photograph shows it inactive and backfilled. The pit was used to burn paper, wood, paint cans, and miscellaneous operations debris. It is possible some low-level radiologically contaminated material was also burned. Geophysical surveys indicate significant quantities of metal beneath the surface.

- Identified Contaminants of Concern: Uranium

- $\quad$ Assumed Excavation Depth (in Areas Above Cleanup Standards): $3.05 \mathrm{~m}$ (10 ft)

- $\quad$ Estimated Soil Volume Above Cleanup Standards: Landfill 1a $=3,971 \mathrm{Icm}$

Landfill $1 \mathrm{~d}=1,078 \mathrm{lcm}$ 
DOE/RL-96-70

Rev. 0

300-FF-1

Operable Unit Boundary

Below Cleanup Standards

Z7A Data Inconclusive

Above Cleanup Standards

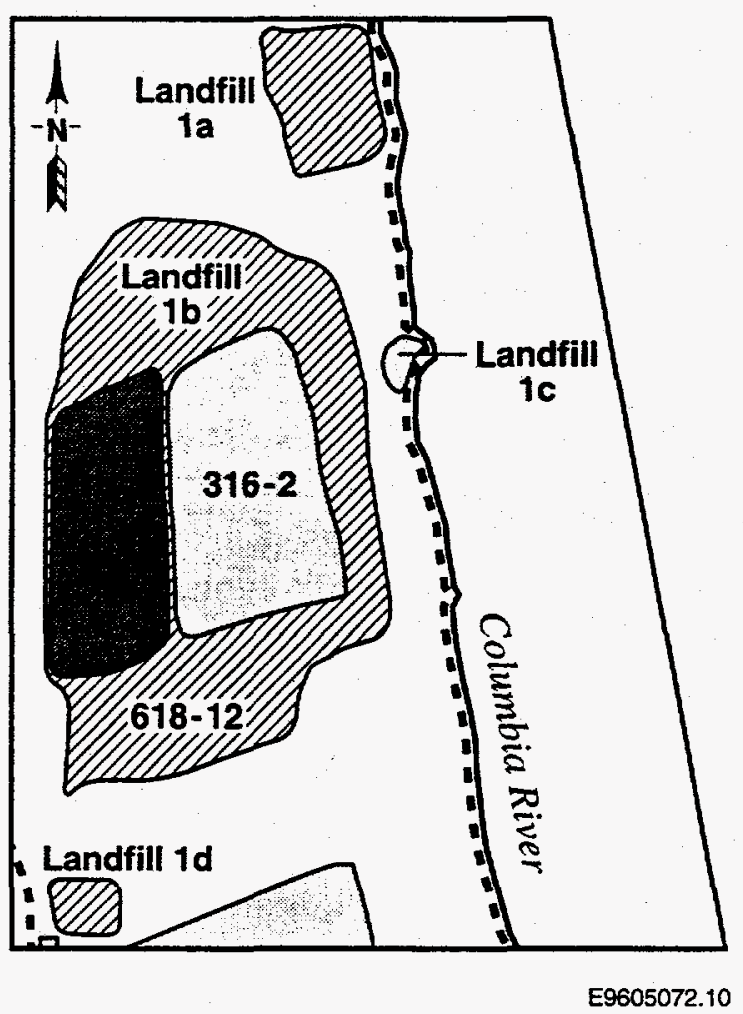


DOE/RL-96-70

Rev. 0

\section{OTHER WASTE SITE GROUPING}

This grouping includes the Sanitary Sewer Trenches, Ash Pits, Filter Backwash Pond, and the Aluminum Hydroxide Site (300-3).

\section{Waste Site Background Summary}

The original 300 Area Sanitary Tile Field was replaced with the first (south) sanitary leach trench in 1948. The second (north) leach trench was constructed in 1952 across portions of the old tile field. During the 300-FF-1 remedial investigation, surface soil samples were collected and analyzed for organic and inorganic contaminants. Levels of chromium and copper were identified, but were below levels of concern. The Phase III Feasibility Study Report for the 300-FF-1 Operable Unit (DOE/RL-94-49) states that no radiological analysis was done.

The Ash Pits received slurried fly ash from the 300 Area coal-burning powerhouse. Soil samples were taken as part of the 300 Area remedial investigation. No contaminants of concern were identified.

The Filter Backwash Pond was constructed in 1987 to replace the Retired Filter Backwash Pond. It was built on an area that was originally part of the South Process Pond. It received backwash from the 300 Area water treatment plant, which contains high concentrations of alum. Soil samples were taken in 1991 as part of the 300 Area remedial investigation. No contaminants of concern were identified. In 1992, the pond was taken out of service to construct a pond liner. Filter backwash water was diverted to the east Ash Pit. Startup of the lined pond was delayed until 1995 due to regulatory issues. The site is currently being used to recycle backwash water back to the treatment plant.

In 1993, a wooden structure and white chalky material were identified near the west end of the Sanitary Sewer Trenches. Historical photographs were examined, and samples of the white material were analyzed. Historical research determined the site was possibly used for pond scraping disposal. The site was given the waste site number 300-3. Sample analysis of the white chalky material confirmed the presence of aluminum hydroxide, but the uranium concentrations were below levels of concern. Pond scrapings typically had high concentrations of uranium.

Based on the results of the remedial investigation, the Sanitary Trenches, Filter Backwash Pond, and the Aluminum Hydroxide Sites are not contaminated and therefore do not require remediation or verification sampling per the Record of Decision. Verification sampling will be performed at the ash pit waste site. Excavation depth, if required, will be determined based on the results of the verification sample analysis. 


\section{DOE/RL-96-70}

Rev. 0

\section{Other Waste Site Grouping}

300-FF-1

Operable Unit Boundary

2 Below Cleanup Standards

VIA Data Inconclusive

Above Cleanup Standards

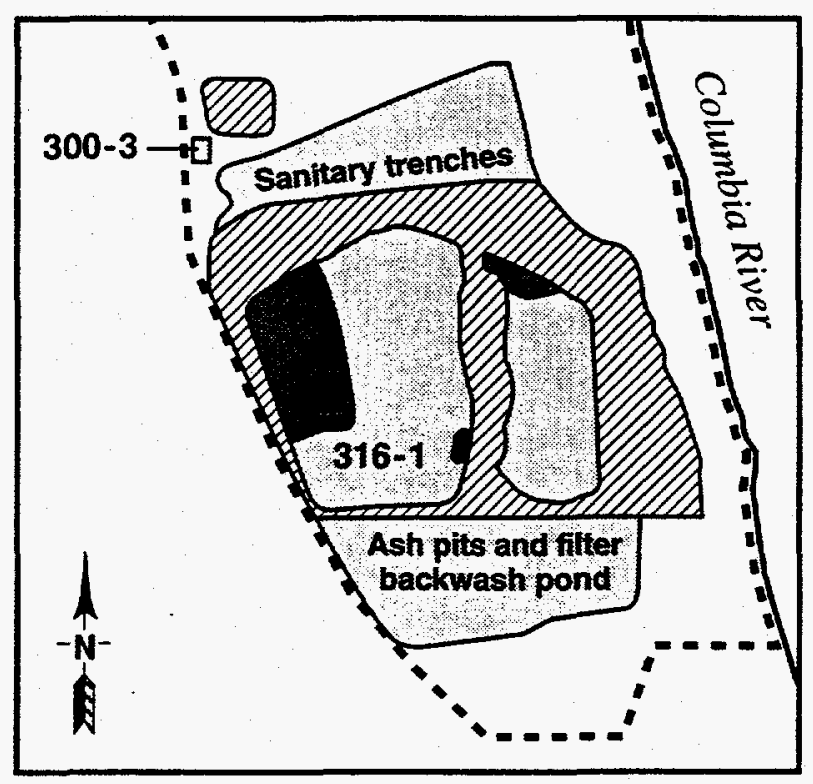

E9605072.5 
DOE/RL-96-70

Rev. 0

A-16 
DOE/RL-96-70

Rev. 0

APPENDIX B

SUMMARY OF RESIDUAL RADIOACTIVITY METHODOLOGY

B-1 
DOE/RL-96-70

Rev. 0

B-2 
DOE/RL-96-70

Rev. 0

\section{APPENDIX B}

\section{SUMMARY OF RESIDUAL RADIOACTIVITY METHODOLOGY}

The purpose of this appendix is to present an evaluation of the potential for future impacts to groundwater from residual contamination in the vadose zone of the 300-FF-1 Operable Unit. Residual contamination refers to contamination remaining the waste site after remediation is complete. The evaluation and conclusions drawn are from an analytical model and a qualitative assessment.

Results of the analytical model are discussed in Section B.1 and, where applicable, depicted in graphical format. The process waste units are modeled as one group, and the burial grounds are modeled as another group. This appendix only describes modeling performed for the selected alternative. Additional modeling efforts were performed in developing and selecting the chosen remedial action. A comprehensive description of the residual radioactivity (RESRAD) modeling effort can be found in the Phase III Feasibility Study Report for the 300-FF-1 Operable Unit (DOE-RL 1995a). A qualitative evaluation of site conditions provides additional information considered in the decision-making process regarding potential for future groundwater impacts from the operable unit. This qualitative evaluation is discussed in Section B.2.

The input parameters used for the selected alternative are found in Table B-1. The conditions established to run the RESRAD model are to generally simulate the "after-cleanup" condition of the operable unit.

A separate RESRAD model was run for each of the waste site groupings for the selective excavation and disposal alternative. The waste site groupings are (1) the process waste units and (2) the burial grounds. The range of residual contamination modeled varies depending on sitespecific conditions of waste groupings discussed in more detail below.

The process waste grouping used a residual contaminant average concentration range of 12 to $50 \mathrm{pCi} / \mathrm{g}$ after remediation. This range of residual contamination brackets the expected condition of the process wastes units after the removal action is completed. For example, if the excavation and disposal alternative were implemented at the North Process Pond, the average remaining uranium soil concentration would be about $25 \mathrm{pCi} / \mathrm{g}$. This would be true if all areas within the North Process Pond containing contamination over $350 \mathrm{pCi} / \mathrm{g}$ were removed during cleanup. Figure B-1 shows the North Process Pond total uranium data, which indicate that the average contaminant concentration would be about $25 \mathrm{pCi} / \mathrm{g}$ if the hot spots were removed from the pond.

The removal of contaminated soil and debris alternative applied to the burial ground waste group used a range of average residual concentrations of 12,25 , and $50 \mathrm{pCi} / \mathrm{g}$. This is expected to bracket the potential range of concentrations of uranium that could be left in the soil at the 618-4 Burial Ground based on the remedial investigation data. 
Table B-1. Input Parameters for Residual Radioactivity Model. (sheet 1 of 2)

\begin{tabular}{|c|c|}
\hline CONTAMIMATED ZONE PARAMETERS & VALUEE \\
\hline AREA OF CONTAMINATION & $205,000 / 21,750$ \\
\hline THICKNESS OF CONTAMINATION & 4 \\
\hline LENGTH PARALLEL TO AQUIFER FLOW & 500 \\
\hline BASIC DOSE LIMIT & 15 \\
\hline TIME SINCE MATERIAL IN GROUND & 40 \\
\hline \multicolumn{2}{|l|}{ COVER/CONTAMINATED ZONE HYDRO DATA UNITS } \\
\hline DENSITY & 1.6 \\
\hline EROSION RATE & .001 \\
\hline TOTAL POROSITY & .3 \\
\hline EFFECTIVE POROSITY & .3 \\
\hline HYDRAULIC CONDUCTIVITY & .0022 \\
\hline "B" PaRAMETER & 15 \\
\hline EVAPOTRANSPIRATION COEFFICIENT & .9 \\
\hline PRECIPITATION & .1524 \\
\hline IARIGATION & 0 \\
\hline IRRIGATION MODE & 0 \\
\hline RUNOFF COEFFICIENT & .2 \\
\hline WATERSHED AREA FOR NEARBY STREAM OR POND & $10^{7}$ \\
\hline ACCURACY OF WATER/SOIL COMPUTATION & .001 \\
\hline SATURATED ZONE HYDROLOGICAL DATA & \\
\hline DENSITY & 1.6 \\
\hline TOTAL POROSITY & .3 \\
\hline EFFECTIVE POROSITY & .3 \\
\hline HYDRAULIC CONDUCTIVITY & 673846 \\
\hline HYORAULIC GRADIENT & .0005 \\
\hline "B" PARAMETER & 3.5 \\
\hline WATER TABLE OROP RATE & .001 \\
\hline WELL PUMP INTAKE DEPTH & 4.6 \\
\hline NON-DISPERSION OR MASS BALANCE & ND \\
\hline WELL PUMPING RATE & 125 \\
\hline
\end{tabular}


Table B-1. Input Parameters for Residual Radioactivity Model. (sheet 2 of 2)

\begin{tabular}{|c|c|}
\hline UNCONTAMINATED ZONE HYDRAULIC PARAMETERS UNITS & VALUE \\
\hline THICKNESS & 5.6 \\
\hline SOIL DENSITY & 1.8 \\
\hline TOTAL POROSITY & .3 \\
\hline EFFECTIVE POROSITY & .3 \\
\hline SOIL SPECIFIC "B" PARAMETER & 15 \\
\hline HYDRAULIC CONDUCTIVITY & .0022 \\
\hline \multicolumn{2}{|l|}{ URANIUM OISTRIBUTION COEFFICIENTS } \\
\hline CONTAMINATED ZONE & 2 \\
\hline UNSATURATED ZONE & 2 \\
\hline SATURATED ZONE & 2 \\
\hline LEACH RATES & NA \\
\hline SOLUBILITY & MA \\
\hline
\end{tabular}

Pre-set parameters for an industrial scenario.

1. Inhalation rate

2. Mass loading for inhalation rate

3. Dilution length for airborne dust

4. Exposure duration

5. Shielding factors

Inhalation

external $\gamma$

6. Time fractions

Indoors (AII work time outdoors)

Outdoors ( $1000 \mathrm{hrs}, 50 \%$ of work time in contamination)

7. Shape factor for external $\gamma$

8. Soil ingestion

9. Drinking water intake

10. Fraction of contaminated drinking water At work Household

11. Depth of soil mixing layer

12. Groundwater/surface water fractional usage Orinking water Household usage
$8400 \mathrm{~m}^{3} /$ year

$.0002 \mathrm{gms} / \mathrm{m}^{3}$

3 meters

30 years

.4

.7

.165

.055

1

$25 \mathrm{gms} / \mathrm{yr}$

$250 \mathrm{l} / \mathrm{yr}$

1

0

.15 meters

1

0 
Rev. 0

Figure B-1. Plot of North Process Pond Uranium Data.

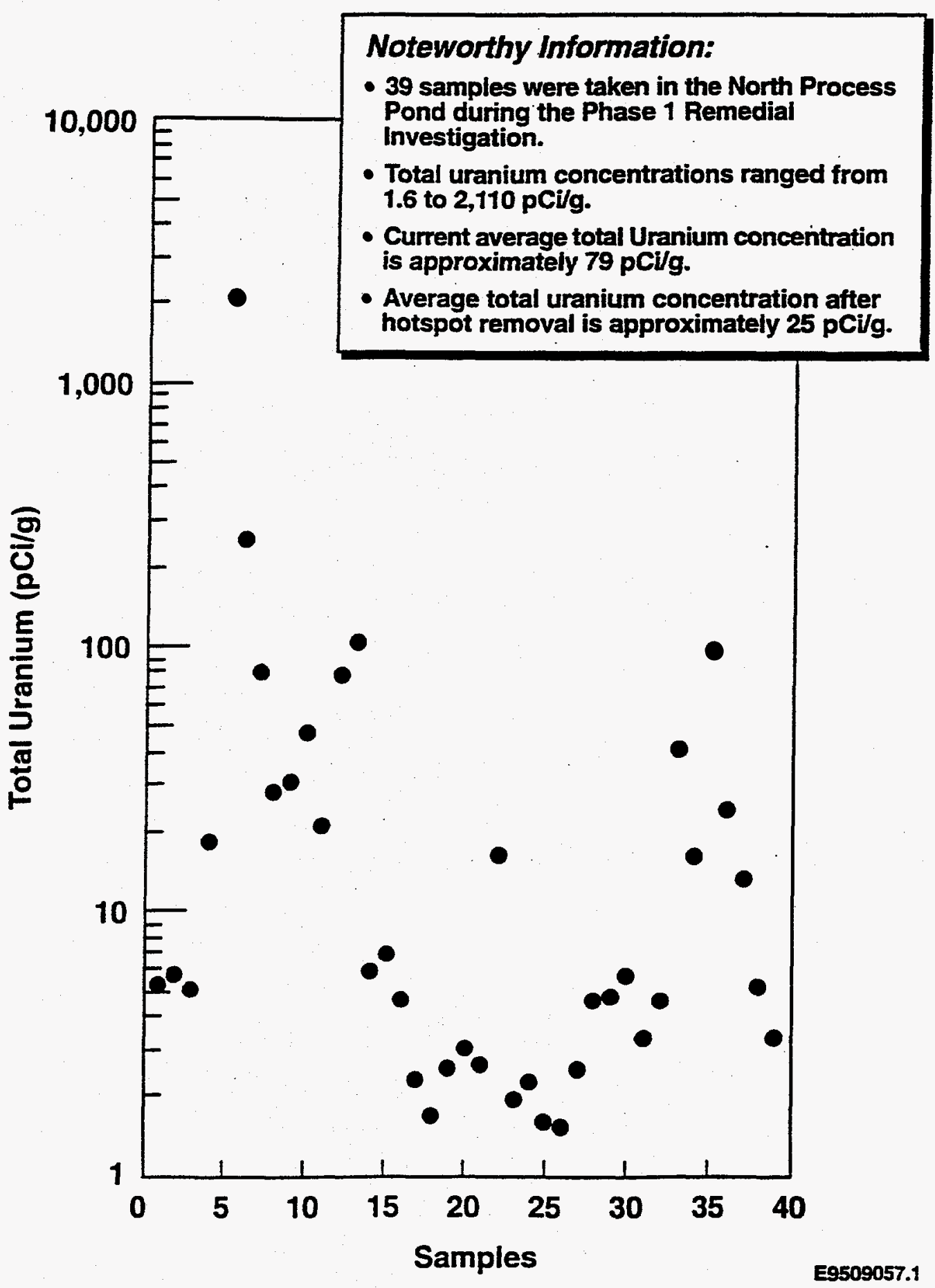


The conceptual model used to represent the 300-FF-1 Operable Unit waste sites consists of a $4-\mathrm{m}-(12 \mathrm{ft})$ thick contaminated zone at the surface of the waste sites with a $5.6-\mathrm{m}(18-\mathrm{ft})$ uncontaminated zone that is between the contaminated zone and the saturated zone or unconfined aquifer. The area of contamination used in the model was $205,000 \mathrm{~m}^{2}\left(2,205,800 \mathrm{ft}^{2}\right)$ and $21,750 \mathrm{~m}^{2}\left(234,030 \mathrm{ft}^{2}\right)$ for the process waste unit and burial ground groupings, respectively.

Cobalt-60 and cesium-137 soil concentrations were not included in this modeling effort. This is because of the relatively short half-lives and/or low concentrations of these radionuclides in the 300-FF-1 Operable Unit soils. Therefore, only the uranium isotopes that have a long half-life and potentially contribute significantly to dose are included in the model.

\section{B.1 RESRAD MODEL RESULTS}

The modeled results for the excavation and disposal alternative show zero impact to groundwater for the burial grounds grouping for 12 and $25 \mathrm{pCi} / \mathrm{g}$ average residual contaminant concentration. At $50 \mathrm{pCi} / \mathrm{g}$ average residual contamination, $6 \mathrm{mrem} / \mathrm{yr}$ is predicted.

The model results for the process waste grouping for the excavate and disposal alternative are shown graphically in Figure B-2. The figure has two ordinate scales, one in $\mathrm{mrem} / \mathrm{yr}$ and the other in $\mathrm{pCi} / \mathrm{L}$. The abscissa is in years modeled using a logarithmic scale. The mrem/yr scale is used to show the potential exposure a worker would receive if groundwater were consumed in the future. The current allowable dose for the groundwater consumption pathway is $4 \mathrm{mrem} / \mathrm{yr}$ based on DOE Order 5400.5, "Radiation Protection of the Public and Environment," a to-beconsidered applicable or relevant and appropriate requirement. The $\mathrm{pCi} / \mathrm{L}$ scale is another form of the model output and represents potential groundwater concentrations. The $20 \mu \mathrm{g} / \mathrm{L}$ proposed maximum contaminant level (MCL) that is based on nonradioactive toxicity equates to approximately $13.6 \mathrm{pCi} / \mathrm{L}$ groundwater concentration assuming enriched uranium.

The process waste grouping model results predict zero concentrations in groundwater for the first 550 years. Then, concentrations of uranium in groundwater start increasing and peak in about 700 years. The peak then drops off to the point where the illustration is ended at 1,000 years. Three residual groundwater exposure levels are shown in Figure B-2. The results show potential exposure from the groundwater consumption pathway to the industrial worker for 12,25 , and $50 \mathrm{pCi} / \mathrm{g}$ residual contamination remaining in the soil, respectively. The average residual contamination remaining after cleanup of the process waste sites is expected to be bracketed by the range of residual contamination modeled. The residual contamination at each waste site will be unique. For example, analysis of current remedial investigation/feasibility study data would suggest a residual contamination level of approximately 25 and $18 \mathrm{pCi} / \mathrm{g}$ for the North and South Process Ponds, respectively. Given this information, the model predicts a peak around $100 \mathrm{pCi} / \mathrm{L}$ for the process waste sites in about 700 years. 
Figure B-2. Dose to the Industrial Worker and Groundwater Concentrations Versus Time for Excavation Alternatives.

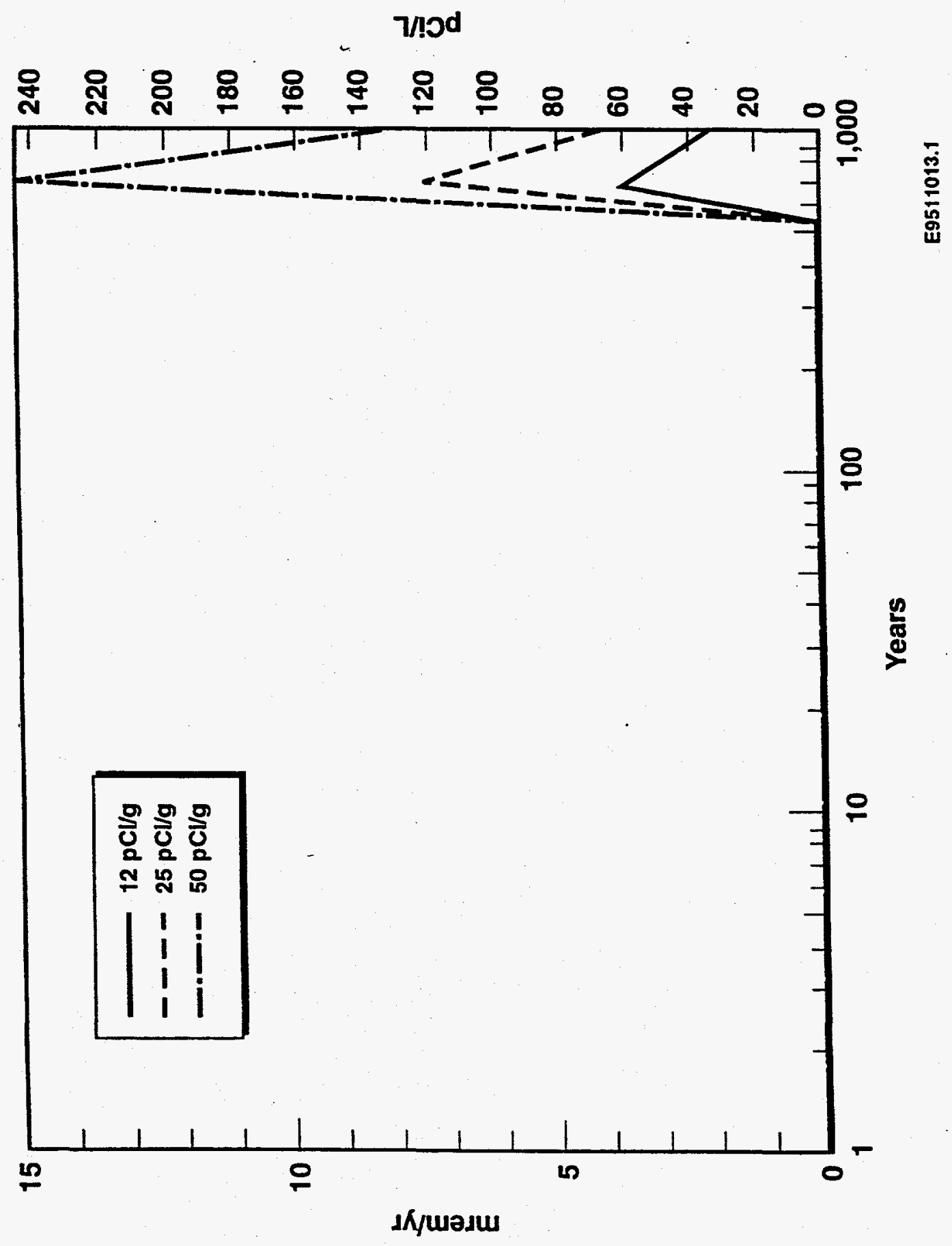


It is not expected that the proposed MCL would be exceeded if the chosen selective excavation and disposal alternative is implemented. This conclusion is based on the following: (1) the model by way of conceptual design creates inherent conservative uncertainties, (2) many of the site-specific sensitive input parameters are based on conservative engineering judgement, (3) the model is predicting no groundwater impacts under any of the waste groupings and alternatives modeled for the first 550 years, and (4) the model is predicting impacts to the groundwater for the process waste sites excavation and removal alternative that are within the bounds of uncertainties discussed above.

\section{B.2 QUALITATIVE EVALUATION}

This section is a qualitative evaluation of processes that affect transport of contaminants through the operable unit. Its purpose is to complement the modeling effort previously discussed and provide a qualitatively presented technical basis for making decisions regarding potential future groundwater impacts. The following qualitative evaluation is mainly directed at uranium contamination; however, other constituents such as copper and organic contaminants are also discussed. A variety of natural processes act to attenuate migration of waste constituents through the environment. These processes include sorption, chemical binding, ion exchange, filtration, diffusion, dispersion, dilution, chemical reaction, biodegradation, and partitioning. Factors associated with these processes that affect contaminant movement in relation to the 300-FF-1 Operable Unit characteristics are discussed in the following subsections.

\section{B.2.2.1 Hydraulic Head}

Current groundwater contamination is a result of past operations, which included an average discharge of $3,500 \mathrm{~L} / \mathrm{min}(900 \mathrm{gal} / \mathrm{min})$ to the process trenches alone (DOE-RL 1995a). However, with this high discharge rate, only the uranium has significantly impacted the groundwater. Discharges to the trenches were discontinued in December 1994; therefore, the driving force for contaminant movement has been significantly reduced to just natural infiltration from precipitation less evapotranspiration.

\section{B.2.2.2 Net Recharge (Rainfall - Evaporation)}

The average annual rainfall on the Hanford Site is limited to about $160 \mathrm{~mm}$ (6.3 in.) because the Cascade Mountain Range creates a rain shadow (increased precipitation in the Cascades results in much less precipitation at the Hanford Site). Evaporation and transpiration from the site varies, mostly depending on the amount of vegetation. As discussed in the 300-FF-5 remedial investigation/feasibility study, a value of $50 \mathrm{~mm} / \mathrm{yr}$ ( 2 in./yr) (DOE-RL 1995b) was determined to approximate the maximum infiltration (net recharge) through the coarse, unvegetated soils in the waste units. This amount of infiltration is significantly lower than infiltration rates during operations and, as demonstrated below, represents a minimal driving force to mobilize contaminants to groundwater. 
Rev. 0

\section{B.2.2.3 Current Groundwater Quality}

Current contamination in the groundwater is limited mainly to uranium. Localized contamination from dichloroethene and trichloroethene is present at a single well cluster. In general, dichloroethene, trichloroethene, and uranium concentrations in groundwater are decreasing through natural attenuation with significant decreases in uranium associated with implementation of the expedited response action at the process trenches. Decreasing concentrations demonstrate that contaminants are not migrating from the vadose zone or that the rate of migration is now less than the natural attenuation rate and continues to decline. Fluctuations in the concentrations are likely associated with varying river stage or to periods of higher precipitation.

\section{B.2.2.4 Depth to Groundwater}

The depth to groundwater in the 300-FF-1 Operable Unit is approximately 6 to $12 \mathrm{~m}$ ( 20 to $40 \mathrm{ft}$ ) below land surface. Most of the contamination associated with the individual waste sites is located in the upper $1.5 \mathrm{~m}(5 \mathrm{ft})$ as shown by the data in Appendix A of the Phase III Feasibility Study Report for the 300-FF-1 Operable Unit (DOE-RL 1995a), leaving approximately 5.5 to $11 \mathrm{~m}$ (18 to $35 \mathrm{ft}$ ) of vadose zone between the contamination and groundwater.

\section{B.2.2.5 Characteristics of the Vadose Zone}

B.2.2.5.1 Permeability and Porosity. The permeability of the vadose zone is a function of porous media (soils), the liquids present (water), and the liquid saturation. The soils in the operable unit have low (approximately 8\%) moisture content (DOE-RL 1993a). Based on analyses documented in the 200-BP-1 Operable Unit remedial investigation/feasibility study, moisture content versus permeability curves were developed for four types of soils including a sandy gravel typical of 300 Area soils (DOE-RL 1993b). Using an average moisture content of $8 \%$ results in a vadose zone permeability of $7 \times 10^{-9} \mathrm{~cm} / \mathrm{sec}$.

Based on a $K_{d}$ of $2 \mathrm{~L} / \mathrm{kg}$ (Serne and Wood 1990, Ames and Serne 1991), the retardation factor for uranium is 11. These parameters are considerations in the travel time of contaminants through the vadose zone, i.e., the higher the retardation factor, the more the movement of the contaminant through the vadose is attenuated. Because the $\mathrm{K}_{\mathrm{d}}$ values for other constituents, such as copper, are higher than uranium, travel times through the vadose zone for these constituents will be even longer.

Leaching Tendencies of Uranium and Regulated Trace Metals from the Hanford Site 300 Area North Process Pond Sediments (Serne et al. 1994) presents results from leaching tests performed on pond sediments and soil-washing fines. The document states that for the mass of metals present in the sediments, neither the water leach tests nor the harsher toxic characteristic leaching procedure (TCLP) ( 40 CFR 261) mobilized a significant fraction of the regulated and other transition metals found in the sediments. For the TCLP tests, a maximum of $18 \%$ of the total mass of uranium in the sediments was leached, whereas only $4 \%$ of the uranium was leached 
during acid rain leach tests for the non-green (not associated with the green layer) sediments and $6 \%$ for the green sediments. For copper, $4 \%$ of the total copper mass in the sediments was leached in the TCLP test, whereas a maximum of $1 \%$ of the mass of copper was leached in the rainwater leach test. Several of the tests used hundreds of pore volumes during the leaching process. These results indicate that the greatly reduced infiltration rate associated with natural processes would not result in significant mobilization of the metals and uranium found in the operable unit.

In addition to the leach tests described above, extraction procedure toxicity and TCLP tests were run on samples collected in Zimmerman and Kossick (1987) and BHI (1995). The samples in both instances were collected from the Process Trenches. The 1987 data were analyzed for metals under the extraction procedure TCLP. All metals passed the test. The 1991 TCLP tests included analysis of metals, pesticides, volatiles, semivolatiles, and herbicides. All of the samples were below regulatory limits. The results of these leach tests strongly indicate very low potential contaminant migration.

Porosity of the vadose zone is approximately $30 \%$ (DOE-RL 1993a). The pore volume of a $100-\mathrm{m}$ by $100-\mathrm{m}$ by $9-\mathrm{m}\left(300-\mathrm{ft}\right.$ by $300-\mathrm{ft}$ by $30-\mathrm{ft}$ ) waste site would be $27,000 \mathrm{~m}^{3}$. A $5-\mathrm{cm} / \mathrm{yr}$ (2-in./yr) infiltration rate from precipitation equates to approximately $500 \mathrm{~m}^{3} / \mathrm{yr}$ through the waste site, or approximately 0.02 pore volumes. Numerous pore volumes would likely be required to move enough mass of contaminants to significantly affect groundwater quality, i.e., at the infiltration rate associated with natural precipitation, the time for sufficient pore volumes of water required to move the contamination to groundwater would be very long, hundreds to thousands of years.

B.2.2.5.2 Clay Content. Fines content is generally below 10\% (DOE-RL 1993a), and clay content even lower. Fines and clay can act as filters, either physical or ion exchange, to bind constituents. Interfaces between fine-grained and more coarsely grained sediments can result in lower movement of water and contaminants. This situation may have occurred at the ponds as evidenced by the infiltration problems that occurred in the past. Pond infiltration rates also decreased during past operations by process sludge and windblown fines. Because of the low clay content, this factor probably does not provide much attenuation of contaminants.

B.2.2.5.3 Organic Matter Content. Carbon content was determined for the operable unit soils during the RI and ranged from $0.2 \%$ to $1.3 \%$. Organics can provide a reducing environment for some constituents, such as uranium, and can increase bioactivity associated with organic contaminants. Because the organic content is low, this parameter probably does not significantly attenuate contaminant movement.

B.2.2.5.4 Ion-Exchange Capacity and pH. The Hanford Site soils have high ion-exchange capacity; this was one of the reasons for the selection of the site for Hanford activities. The $\mathrm{pH}$ of the soils is generally basic, which tends to limit the leaching potential of most metals by neutralizing any potential acidic infiltrations. 
DOE/RL-96-70

Rev. 0

\section{B.2.2.6 Contaminant Characteristics}

B.2.2.6.1 Volatility. The metals are not volatile. The organics present in the operable unit are volatile, and contaminant mobility may be increased by potential vapor transport. However, organic contamination is localized and concentrations are low.

B.2.2.6.2 Degradability or Biologic Activity. Uranium undergoes natural radioactive decay. However, because the half-life of uranium-238 is $4.7 \times 10^{9}$ years, decay is not significant. Inorganic constituents do not tend to degrade in the environment. Organic contaminants generally experience both degradation and biologic activity that reduce their concentrations over time.

\section{B.2.2.7 Other Constituents That Could Affect Mobility}

Effects on mobility from other constituents are not anticipated. Discharges to the Process Trenches have been discontinued. It is expected that institutional controls, at a minimum, will limit future potential discharges should the U.S. Department of Energy release control of the site.

\section{B.2.2.8 Topography}

The topography is generally flat and slightly irregular. A steep embankment is present at the Columbia River. Surface runoff in this area is low because there are no well-defined drainage channels, surface soils are highly permeable, evapotranspiration is high, and runoff has not been directly observed or reported.

\section{B.2.2.9 Total Contaminant Load (Mass Loading)}

Contaminant concentrations within the soils are generally higher within the upper $1.5 \mathrm{~m}(5 \mathrm{ft})$ of the vadose zone. High concentrations are associated with localized hot spots. Other concentrations are generally much lower than the hot spot concentrations. The highest concentrations are associated with the inlets of the liquid waste units. The expedited response action performed at the Process Trenches removed a major hot spot source of uranium and RCRA contaminants associated with the trench inlets and consolidated the excavated soils in an area at the north end of the Process Trenches. The spoils area was covered with a plastic barrier and a layer of clean aggregate. This expedited response action mitigated the effects of infiltration from both operations and precipitation. This spoils area represents the highest uranium concentrations.

\section{B.2.2.10 Volumetric Groundwater Flow Rate}

Because of high conductivity in the saturated zone [3,600 m/day mean (DOE-RL 1995b)], the volumetric flow rate is high. This results in greater natural attenuation of contaminants when they reach the aquifer. 


\section{B.2.2.11 Uncertainty of the Data and Assumptions}

While the quality of the contaminant concentration data is good, the amount of data is limited, especially for the burial grounds. However, because the burial grounds did not receive large volumes of liquids as the trenches and ponds did, contaminants have likely not migrated from original placement. The contamination in the burial grounds is mostly in the form of solids or soft wastes that would be less susceptible to leaching from natural infiltration.

\section{B.3 CONCLUSIONS}

The purpose of this appendix is to evaluate the potential for residual contamination in the $300-F F-1$ Operable Unit to cause an adverse impact to the groundwater in the future. In the near term ( 3 to 10 years), groundwater is predicted to be cleaned to below the proposed drinking water standard based on analysis performed in the 300-FF-5 Operable Unit remedial investigation/ feasibility study (DOE-RL 1995b). Therefore, this effort is focused on long-term future predictions beyond 10 years up to 1,000 years. The conclusion drawn from the analysis presented in this appendix is that there is minimal potential for significant future groundwater impact.

The conclusion is based on engineering judgement factoring in all of the data presented in the qualitative analysis and the results of the model. The qualitative analysis examined physicochemico properties of $300-\mathrm{FF}-1$ soils and contaminants. Evaluation of these properties present strong physical evidence that any migration of $300-\mathrm{FF}-1$ residual contaminants in the future would be extremely slow and at low concentrations. Of particular significance are the TCLP, results which have conclusively measured the slow leaching potential of 300-FF-1 contaminants and the lack of any significant driving force to mobilize contaminants.

The RESRAD model was used as another tool to help evaluate potential future groundwater impact. RESRAD can only model radionuclides and therefore was used to evaluate uranium, which is the major contaminant of concern for the $300-\mathrm{FF}-1$ Operable Unit. The model is used as a predictive tool but has limitations that must be factored into the analysis. The RESRAD groundwater code is based on a simplistic conceptual model of a generalized site that is not capable of factoring all of the site-specific conditions. This would suggest that the model would tend to predict higher impacts than may be realistic. Another key factor that can provide conservatism in the model predictions are the input parameters. Several of the sensitive soil and groundwater properties used in the model are potentially very conservative. However, erring on the conservative side for these sensitive parameters was deemed appropriate. The conservatism inherent in the model and sensitive input parameters cause increasing uncertainty with the model predictions over time. The model is capable of predicting up to 10,000 years but, realistically, has only been benchmark checked at 500 years. Therefore, the model was only run for a 1,000 -year period with a lowered degree of confidence beyond 500 years. 
DOE/RL-96-70

Rev. 0

The model predicts none to low potential for groundwater impacts for both of the waste grouping for the excavation alternative depending on the average concentration of residual contamination remaining in 300-FF-1. Removing contaminated soils to the proposed $15-\mathrm{mrem} / \mathrm{yr}$ cleanup standard would result in low average residual contamination such that groundwater would not be impacted for the reasons discussed above. In summary, the qualitative evaluation of 300-FF-1 soil and contaminant transport properties coupled with the RESRAD model results strongly suggest no future impact to groundwater from the 300-FF-1 Operable Unit from residual contamination.

\section{B.4 REFERENCES}

Ames, L. L. and R. J. Serne, 1991, Compilation of Data to Estimate Groundwater Mitigation Potential for Constituents in Active Liquid Discharges at the Hanford Site, PNL-7660, Pacific Northwest Laboratory, Richland, Washington.

BHI, 1995, 300-FF-1 Phase 1 Remedial Investigation TCLP Data, BHI-00452, Rev. 0, Bechtel Hanford, Inc., Richland, Washington.

DOE-RL, 1993a, Phase I Remedial Investigation Report for the 300-FF-1 Operable Unit, DOE/RL-92-43, Rev. 0, U.S. Department of Energy, Richland Operations Office, Richland, Washington.

DOE-RL, 1993b, Phase 1 Remedial Investigation Report for 200-BP-1 Operable Unit, DOE/RL-92-70, Rev. 0, U.S. Department of Energy, Richland Operations Office, Richland, Washington.

DOE-RL, 1995a, Phase III Feasibility Study Report for the 300-FF-1 Operable Unit, DOE/RL-94-49, Rev. 0, U.S. Department of Energy, Richland Operations Office, Richland, Washington.

DOE-RL, 1995b, Remedial Investigation/Feasibility Study for the 300-FF-5 Operable Unit, DOE/RL-94-85, Rev. 0, U.S. Department of Energy, Richland Operations Office, Richland, Washington.

Serne, R. J. and M. I. Wood, 1990, Hanford Waste-Form Release and Sediment Interaction: A status Report with Rationale and Recommendations for Additional Studies, PNL-7297, Pacific Northwest Laboratory, Richland, Washington.

Serne, R. J, V. L. LeGore, and S. V. Mattigod, 1994, Leaching Tendencies of Uranium and Regulated Trace Metals from the Hanford Site 300 Area North Process Pond Sediments, PNL-10109, Pacific Northwest Laboratory, Richland, Washington.

Zimmerman, M. G. and C. D. Kossick, 1987, 300 Area Process Trench Sediment Analysis Report, WHC-SP-0193, Westinghouse Hanford Company, Richland, Washington. 
DOE/RL-96-70

Rev. 0

APPENDIX C

SAMPLING AND ANALYSIS PLAN

C-1 
DOE/RL-96-70

Rev. 0

C-2 
DOE/RL-96-70

Rev. 0

\section{APPENDIX C}

SAMPLING AND ANALYSIS PLAN

CONTENTS

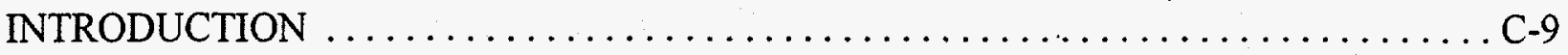

PART I PROJECT BACKGROUND AND RATIONALE FOR SAMPLING AND ANALYTICAL STRATEGIES $\ldots \ldots \ldots \ldots \ldots \ldots \ldots \ldots \ldots \ldots \ldots \ldots \ldots$

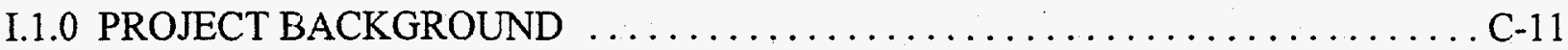

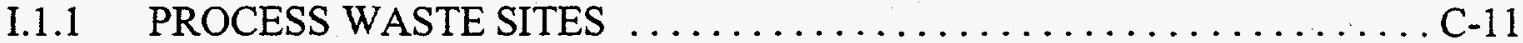

I.1.2 BURIAL GROUND AND LANDFILLS $\ldots \ldots \ldots \ldots \ldots \ldots \ldots \ldots \ldots \ldots \ldots \ldots \ldots$

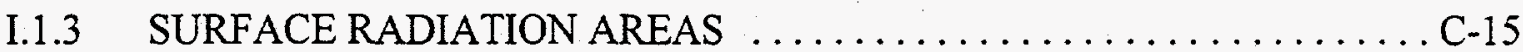

I.2.0 CONTAMINANTS OF CONCERN AND CLEANUP LEVELS $\ldots \ldots \ldots \ldots \ldots$ C-16

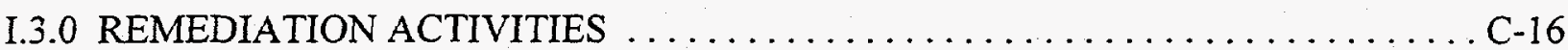

I.4.0 SAMPLING AND ANALYTICAL STRATEGIES $\ldots \ldots \ldots \ldots \ldots \ldots \ldots \ldots$ C-16

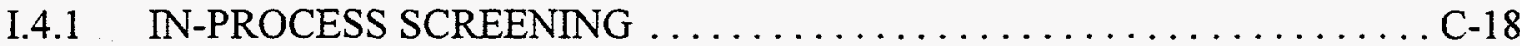

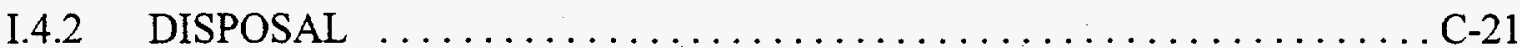

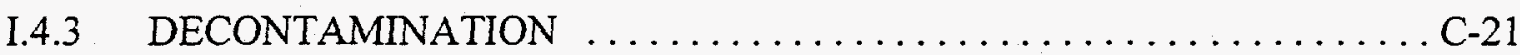

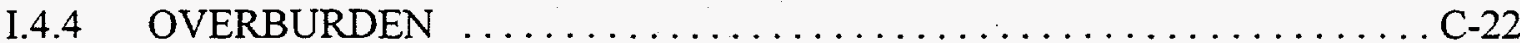

I.4.5 VERIFICATION $\ldots \ldots \ldots \ldots \ldots \ldots \ldots \ldots \ldots \ldots \ldots \ldots \ldots \ldots \ldots \ldots \ldots \ldots \ldots \ldots, 22$

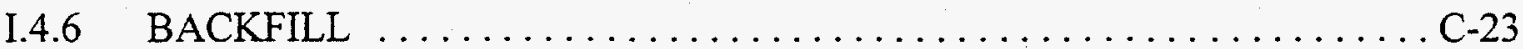

I.4.7 DEBRIS AND STRUCTURES $\ldots \ldots \ldots \ldots \ldots \ldots \ldots \ldots \ldots \ldots \ldots \ldots \ldots \ldots \ldots \ldots$

PART II

QUALITY ASSURANCE PROJECT PLAN $\ldots \ldots \ldots \ldots \ldots \ldots \ldots \ldots \ldots \ldots \ldots \ldots \ldots \ldots$

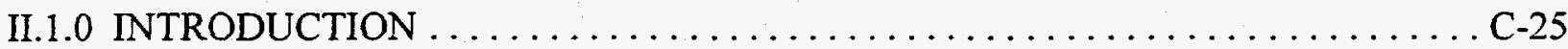

II.2.0 PROJECT MANAGEMENT/DATA QUALITY OBJECTIVES $\ldots \ldots \ldots \ldots \ldots \ldots$ C-25

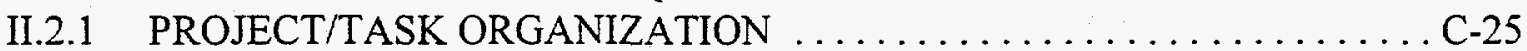

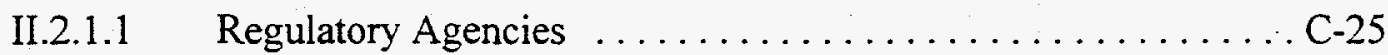

II.2.1.2 U.S. Department of Energy . ................. C-25

II.2.1.4 Remedial Action Subcontractor . . . . . . . . . . . . . 26

II.2.2 PROBLEM DEFINITION/BACKGROUND $\ldots \ldots \ldots \ldots \ldots \ldots \ldots \ldots$ C-26 
DOE/RL-96-70

Rev. 0

CONTENTS (Continued)

II.2.3 QUALITY OBJECTIVES AND CRITERIA FOR MEASUREMENT

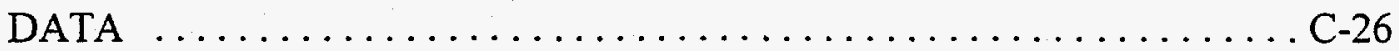

II.2.4 PROJECT NARRATIVE . . . . . . . . . . . . . . . . . . . . C-29

II.2.5 SPECIAL TRAINING REQUIREMENTS/CERTIFICATION $\ldots \ldots \ldots \ldots$ C-32

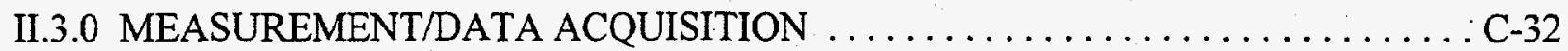

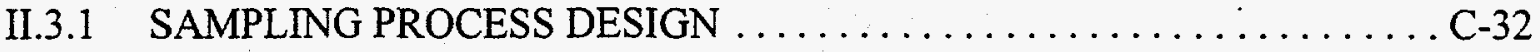

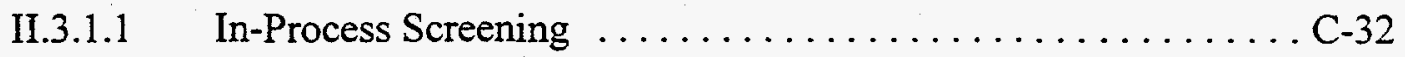

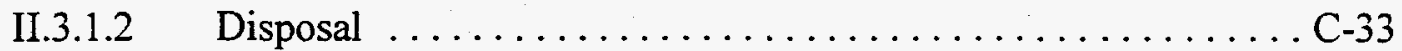

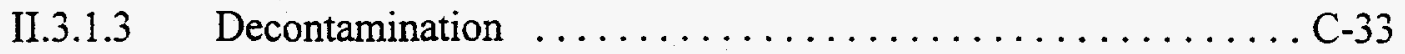

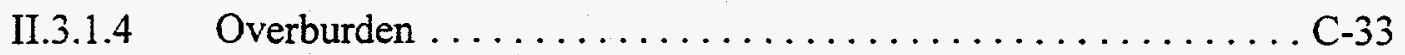

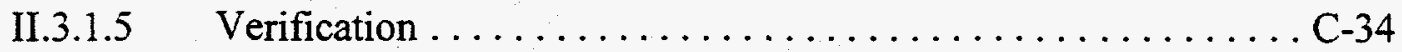

II.3.1.6 Backfill ..............................

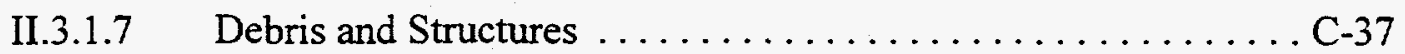

II.3.2 ANALYTICAL METHOD REQUIREMENTS $\ldots \ldots \ldots \ldots \ldots \ldots \ldots$ C-38

II.3.3 QUALITY CONTROL REQUIREMENTS $\ldots \ldots \ldots \ldots \ldots \ldots \ldots \ldots . . .39$

II.3.4 INSTRUMENT/EQUIPMENT TESTING, INSPECTION, AND

MAINTENANCE REQUIREMENTS $\ldots \ldots \ldots \ldots \ldots \ldots \ldots \ldots$ C-39

II.3.5 INSPECTION/ACCEPTANCE REQUIREMENTS FOR SUPPLIES AND

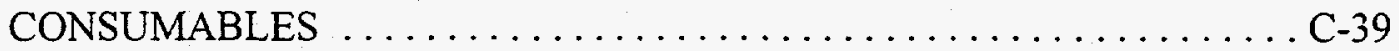

II.3.6 DATA ACQUISITION REQUIREMENTS (NONDIRECT

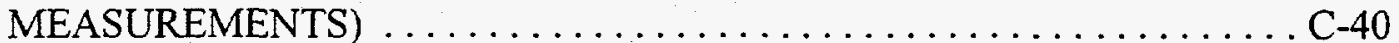

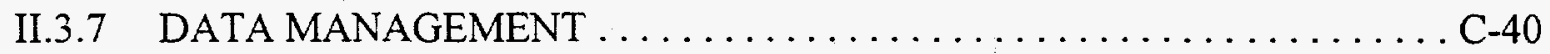

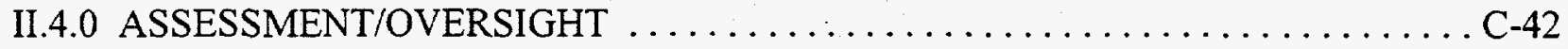

II.4.1 ASSESSMENTS AND RESPONSE ACTIONS $\ldots \ldots \ldots \ldots \ldots \ldots \ldots$ C-42

II.4.2 REPORTS TO MANAGEMENT $\ldots \ldots \ldots \ldots \ldots \ldots \ldots \ldots \ldots \ldots \ldots \ldots \ldots \ldots \ldots \ldots$

II.5.0 DATA VALIDATION AND USABILITY $\ldots \ldots \ldots \ldots \ldots \ldots \ldots \ldots \ldots \ldots$ C-42

II.5.1 DATA REVIEW, VALIDATION, AND VERIFICATION

REQUIREMENTS ........................... -42

II.5.2 VALIDATION AND VERIFICATION METHODS $\ldots \ldots \ldots \ldots \ldots \ldots C-43$

II.5.3 RECONCILIATION WITH USER REQUIREMENTS $\ldots \ldots \ldots \ldots \ldots$. C-43

II.5.3.1 Precision . . . . . . . . . . . . . . . . . . . . .

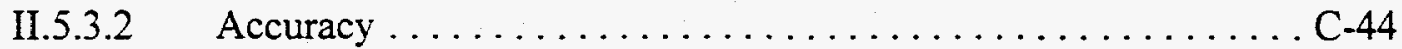

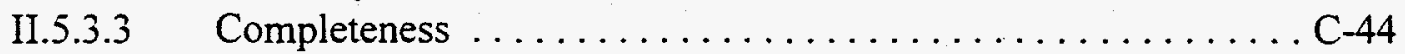

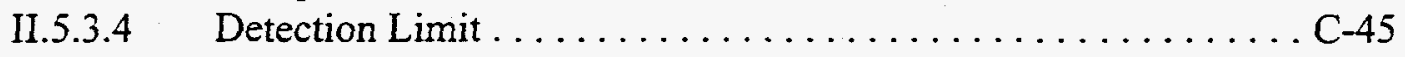


DOE/RL-96-70

Rev. 0

\section{CONTENTS (Continued)}

PART III

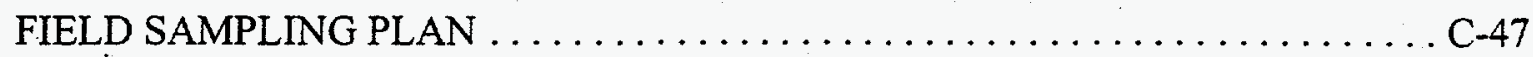

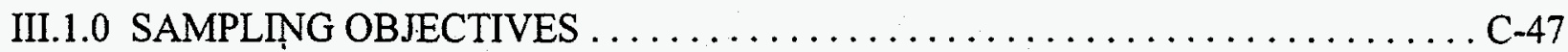

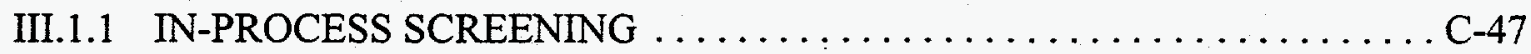

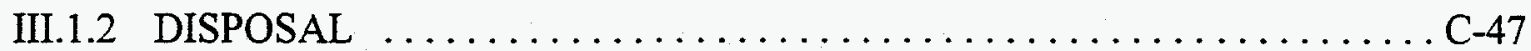

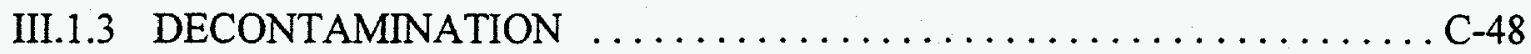

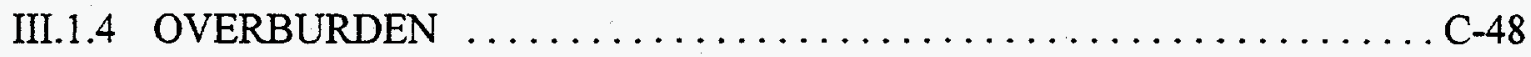

III.1.5 VERIFICATION $\ldots \ldots \ldots \ldots \ldots \ldots \ldots \ldots \ldots \ldots \ldots \ldots \ldots \ldots \ldots \ldots \ldots \ldots \ldots, 48$

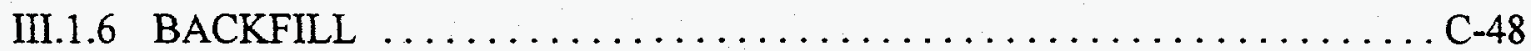

III.1.7 DEBRIS AND STRUCTURES $\ldots \ldots \ldots \ldots \ldots \ldots \ldots \ldots \ldots \ldots \ldots \ldots \ldots \ldots$

III.2.0 SAMPLING LOCATIONS AND FREQUENCIES $\ldots \ldots \ldots \ldots \ldots \ldots \ldots$ C-49

III.3.0 SAMPLING METHODS $\ldots \ldots \ldots \ldots \ldots \ldots \ldots \ldots \ldots \ldots \ldots \ldots \ldots \ldots \ldots \ldots \ldots \ldots \ldots$

III.4.0 FIELD QUALITY CONTROL SAMPLING $\ldots \ldots \ldots \ldots \ldots \ldots \ldots \ldots \ldots$ C-54

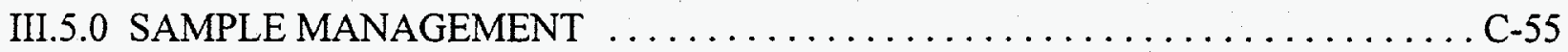

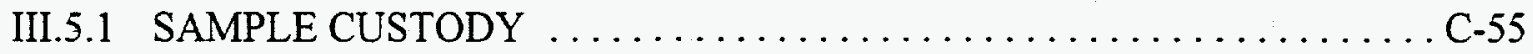

III.5.1.1 Field Custody .......................

III.5.1.2 Laboratory Custody Procedures ................. -56

III.5.2 SAMPLE PRESERVATION, CONTAINERS, AND HOLDING TIMES . . C C-56

III.5.3 SAMPLE SHIPPING $\ldots \ldots \ldots \ldots \ldots \ldots \ldots \ldots \ldots \ldots \ldots \ldots \ldots \ldots \ldots \ldots \ldots$

III.5.4 FIELD DOCUMENTATION $\ldots \ldots \ldots \ldots \ldots \ldots \ldots \ldots \ldots \ldots \ldots \ldots \ldots \ldots$

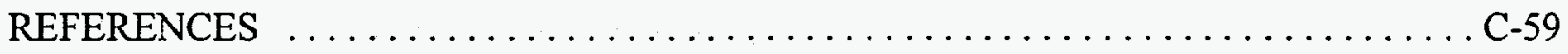

\section{ATTACHMENT:}

1 SAMPLE LOCATION COORDINATES $\ldots \ldots \ldots \ldots \ldots \ldots \ldots \ldots \ldots \ldots \ldots \ldots \ldots \ldots$

\section{FIGURES:}

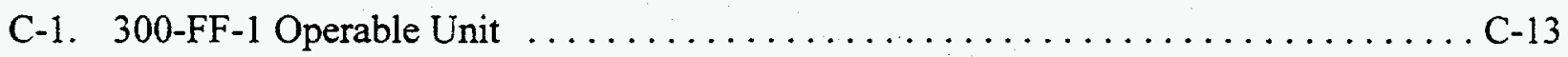

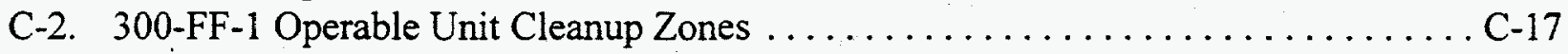

C-3. Sample and Data Management Process Flow ..................... C-41 
DOE/RL-96-70

Rev. 0

\section{CONTENTS (Continued)}

C-4. Sample Locations in Northern Waste Sites . . . . . . . . . . . . . . C-52

C-5. Sample Locations in Southern Waste Sites . . . . . . . . . . . . . . . C-53

\section{TABLES:}

C-1. Contaminants of Concern and Maximum Concentrations in the

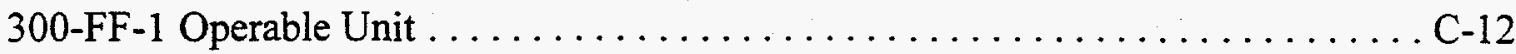

C-2. Data Uses and Required Limits $\ldots \ldots \ldots \ldots \ldots \ldots \ldots \ldots \ldots \ldots \ldots \ldots \ldots \ldots \ldots \ldots \ldots$

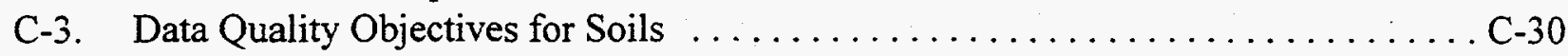

C-4. Data Quality Objectives for Water .......................

C-5. Waste Site/Subsite Contaminant Distribution, Mean, and Standard Deviation . . . . . C-35

C-6. Components of Total Sample Error and Measures Taken to Reduce That Error . . . C-36

C-7. Analytical Standard Operating Procedures $\ldots \ldots \ldots \ldots \ldots \ldots \ldots \ldots \ldots \ldots \ldots$

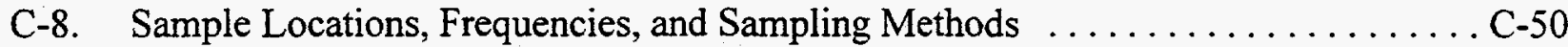

C-9. Field Quality Control Sampling Requirements Summary . . . . . . . . . . . . C-55

C-10. Sample Containers, Types, Preservation, and Holding Times . . . . . . . . . . C-57 
DOE/RL-96-70

Rev. 0

\section{ACRONYMS}

COC

DOE

DQO

Ecology

EPA

ERC

ERDF

FID

GPR

GPS

HEIS

HGIS

MDA

MTCA

OSHA

OVA

OVM

PID

QA/QC

QAPjP

RAS

RCRA

RCT

RESRAD

RI/FS

ROD

SAP

SDG

UCL

VOC

WIDS

XRF

contaminant of concern

U.S. Department of Energy

data quality objective

Washington State Department of Ecology

U.S. Environmental Protection Agency

Environmental Restoration Contractor

Environmental Restoration Disposal Facility

flame ionization detector

ground penetrating radar

Global Positioning System

Hanford Environmental Information System

Hanford Geographical Information System

minimum detectable activity

Model Toxics Control Act

Occupational Safety and Health Administration

organic vapor analyzer

organic vapor monitor

portable photoionization detector

quality assurance/quality control

Quality Assurance Project Plan

remedial action subcontractor

Resource Conservation and Recovery Act of 1976

Radiological Control Technician

Residual Radioactivity (dose assessment model)

remedial investigation/feasibility study

Record of Decision

sampling and analysis plan

sample delivery group

upper confidence limit

volatile organic compound

Waste Information Data System

$\mathrm{x}$-ray fluorescence 



\section{INTRODUCTION}

This sampling and analysis plan (SAP) presents the rationale and strategies for the sampling, field measurements, and analyses that will be conducted during the remediation of the 300-FF-1 Operable Unit waste sites. The rationale, strategies, and field measurement and analysis techniques were discussed, debated, and agreed to by the 300-FF-1 Operable Unit decision makers during the 300-FF-1 SAP data quality objectives (DQO) process. The culmination of the DQO process is documented in a series of signed meeting minutes included in the 300-FF-1 Remedial Action Sampling and Analysis Plan DQO Process Summary Report (BHI 1996a).

All but one of the waste sites are past-practice waste units that are being remediated in accordance with the Record of Decision (ROD) (EPA 1996). The 300 Area Process Trenches site is a Resource Conservation and Recovery Act (RCRA) disposal site within 300-FF-1 that is being closed under Modification B to the Hanford RCRA Facility-Wide Permit and the 300 Area Process Trenches Modified Closure/Postclosure Plan (DOE-RL 1995a). This SAP is organized into three parts:

PART I

PART II

PART III
Describes the project background and rationale for conducting sampling and analyses to both guide the remediation and verify attainment of cleanup levels.

Presents the Quality Assurance Project Plan (QAPjP) that documents the activities and procedures to be used to obtain data of known and appropriate quality.

Presents the Field Sampling Plan that documents the field procedures to be used to obtain data of known and appropriate quality. 
DOE/RL-96-70

Rev. 0

C-10 
DOE/RL-96-70

Rev. 0

\section{PART I}

\section{PROJECT BACKGROUND AND RATIONALE FOR SAMPLING AND ANALYTICAL STRATEGIES}

\section{I.1.0 PROJECT BACKGROUND}

The 300-FF-1 Operable Unit includes waste and contaminated vadose zone soils for the major process liquid waste disposal sites in the 300 Area of the Hanford Site. Remedial investigation/feasibility study (RI/FS) activities investigated surface and vadose zone soils and site ecology. The contaminants of concern (COCs) and maximum values detected within the 300-FF-1 Operable Unit are shown in Table C-1. Uranium is the primary contaminant within the 300-FF-1 waste sites. Some chemical contaminants above the Model Toxics Control Act (MTCA) (WAC 173-340-745) Method C, "Industrial Soil Cleanup Values," are localized mainly in the Process Trenches Spoils Pile.

The waste sites can be divided into two categories: (1) Process Waste Sites and (2) Burial Ground and Landfills (Figure C-1). The 618-5 Burial Ground is part of the 300-FF-2 Operable Unit. The following discussion identifies the waste units by both common name and the Hanford Site Waste Information Data System (WIDS) reference number.

\section{I.1.1 PROCESS WASTE SITES}

The 300-FF-1 Process Waste Sites are the South Process Pond (316-1), North Process Pond (316-2), North Process Pond Scraping Disposal Area (618-12), Process Trenches (316-5), Process Trenches Spoils Pile, Process Sewers, the Ash Pits, Filter Backwash Pond, Retired Filter Backwash Pond, and Sanitary Tile Field and Trenches and other sanitary system components.

The South and North Process Ponds were built in 1943 and 1948, respectively. Combined, they received large volumes of process wastes ranging from 1,514,000 to $11,360,000 \mathrm{~L} /$ day $(400,000$ to $3,000,000 \mathrm{gal} / \mathrm{day}$ ) from the fuel fabrication activities in the 300 Area. Over the operational life of these ponds, thousands of kilograms of uranium were discharged during operations, some of which was flushed to the groundwater and some of which remains in the pond soils at present. The COCs are uranium and cobalt-60. The ponds were scraped out periodically to increase infiltration, and the scraped material was placed along the interior dikes and sides of the ponds. Discharging of waste to the process ponds stopped in 1975.

The North Process Pond Scrapings Disposal Area is adjacent to the south boundary of the North Process Pond. This area was used to dispose of pond sludges as well as soil from beneath the 321 Building. This area has since been covered with coal ash and clean fill and then was used to store equipment from the canceled Clinch River reactor project (DOE-RL 1995b). 
DOE/RL-96-70

Rev. 0

Table C-1. Contaminants of Concern and Maximum Concentrations in the 300-FF-1 Operable Unit.

\begin{tabular}{|c|c|c|c|}
\hline Contaminants of Concern & $\begin{array}{l}\text { Maximum Concentration } \\
\text { Detected in Soils }\end{array}$ & $\begin{array}{l}\text { Cleanup } \\
\text { Levels }\end{array}$ & $\begin{array}{c}\text { Source of } \\
\text { Cleanup Level }\end{array}$ \\
\hline Cobalt -60 & $81 \mathrm{pCi} / \mathrm{g}$ & \multirow{4}{*}{$15 \mathrm{mrem} / \mathrm{yr}^{\mathrm{b}}$} & \multirow{4}{*}{40 CFR $196^{\circ}$} \\
\hline Uranium-234 & $9,700 \mathrm{pCi} / \mathrm{g}$ & & \\
\hline Uranium-235 & $1,600 \mathrm{pCi} / \mathrm{g}$ & & \\
\hline Uranium-238 & $9,143 \mathrm{pCi} / \mathrm{g}$ & & \\
\hline Arsenic $^{d}$ & $319 \mathrm{mg} / \mathrm{kg}$ & $219 \mathrm{mg} / \mathrm{kg}$ & MTCA $^{\mathrm{e}}$ \\
\hline Benzo(a)pyrene ${ }^{d}$ & $27 \mathrm{mg} / \mathrm{kg}$ & $18 \mathrm{mg} / \mathrm{kg}$ & $\mathrm{MTCA}^{\mathrm{e}}$ \\
\hline Chrysene $^{d}$ & $43 \mathrm{mg} / \mathrm{kg}$ & $18 \mathrm{mg} / \mathrm{kg}$ & $\mathrm{MTCA}^{\mathrm{e}}$ \\
\hline Polychlorinated biphenyls & $42 \mathrm{mg} / \mathrm{kg}$ & $17 \mathrm{mg} / \mathrm{kg}$ & $\mathrm{MTCA}^{\mathrm{e}}$ \\
\hline Thallium $^{d}$ & $25,000 \mathrm{mg} / \mathrm{kg}$ & $245 \mathrm{mg} / \mathrm{kg}$ & $\mathrm{MTCA}^{\mathrm{e}}$ \\
\hline
\end{tabular}

Source: Record of Decision for the U.S. Department of Energy Hanford 300-FF-1 and 300-FF-5 Operable Units (EPA 1996).

aData presented are maximum levels found in soils. These contaminant levels are limited to only a few areas.

${ }^{b}$ Residual radioactivity modeling based on a regulator-approved industrial exposure scenario is used to convert between dose levels $(\mathrm{mrem} / \mathrm{yr})$ and soil concentrations $(\mathrm{pCi} / \mathrm{g})$. For example, the $15-\mathrm{mrem} / \mathrm{yr}$ dose equates to $350-\mathrm{pCi} / \mathrm{g}$ concentration from total uranium-234, uranium-235, and uranium-238.

'40 CFR 196 is a draft regulation identified in an advanced notice of proposed rulemaking at 58 FR 54474.

${ }^{\mathrm{d}}$ Contaminants found only in the Process Trenches Spoils Pile. When uranium is removed to the Comprehensive Environmental Response, Compensation, and Liability Act of 1980 cleanup standard of $350 \mathrm{pCi} / \mathrm{g}$, the chemical contaminants of concern will likely be removed to below the Model Toxics Control Act (MTCA) Method C cleanup standards, so in-process screening for uranium can be used to guide remediation.

"State of Washington, MTCA Method C, "Industrial Cleanup Values for Soils" (MTCA Cleanup Levels and Risk Calculations, update February 26, 1996). 
DOE/RL-96-70

Rev. 0

Figure C-1. 300-FF-1 Operable Unit.

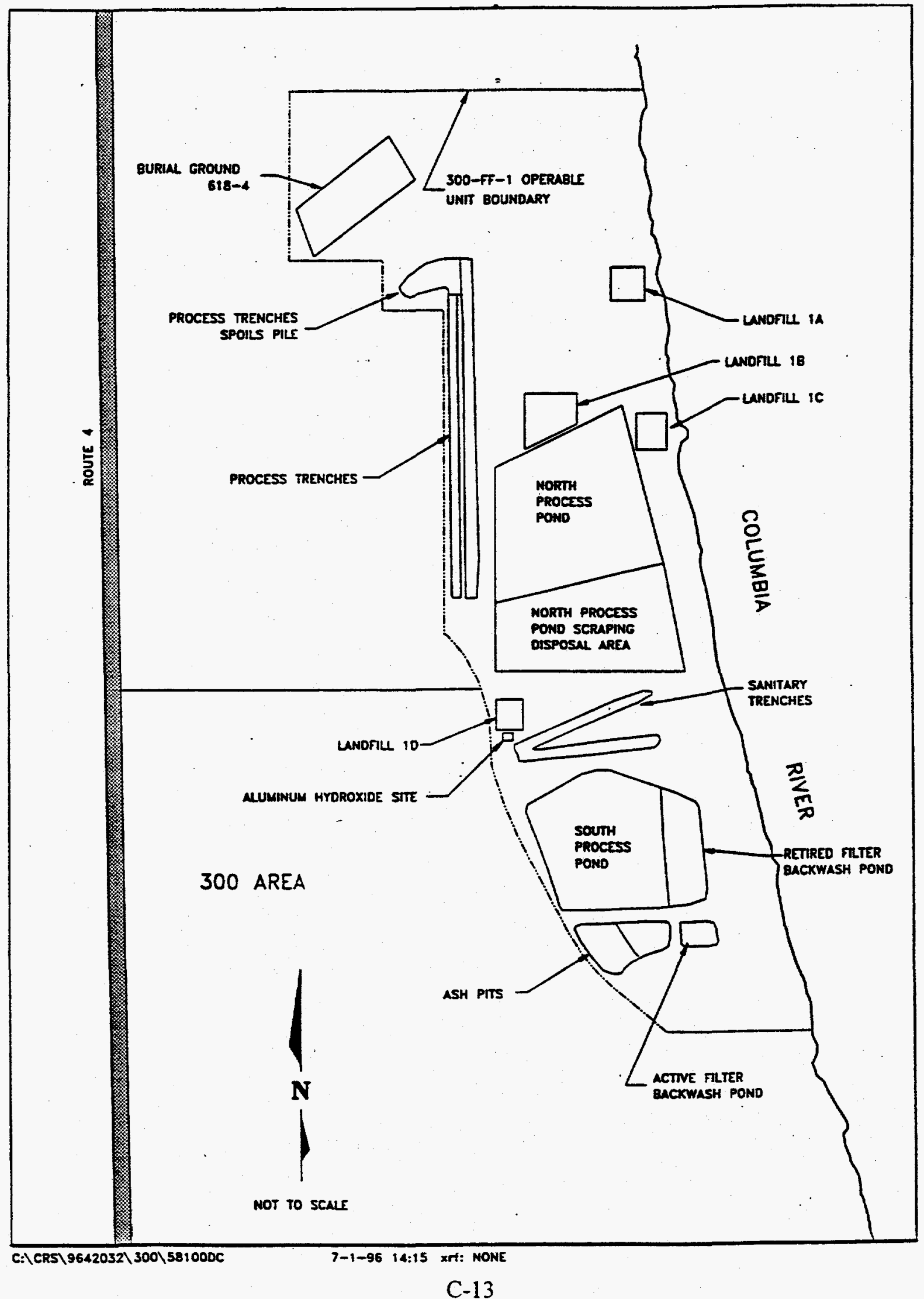


The Process Trenches were built in 1975 to replace the process ponds. Like the North and South Process Ponds, the Process Trenches received large volumes of process waste with peak discharges up to $7,900 \mathrm{~L} / \mathrm{min}(2,000 \mathrm{gal} / \mathrm{min})$. The COCs are uranium, cobalt- 60 , arsenic, benzo(a)pyrene, chrysene, polychlorinated biphenyls, and thallium. In 1991, contaminated soils from the south end of the Process Trenches were moved to the dry north end, creating the Process Trenches Spoils Pile. This expedited response action stopped process waste from passing through the contaminated soil and transporting contamination into the groundwater. Uranium concentrations in the underlying groundwater decreased rapidly after the soils were removed (DOE-RL 1993a). Discharges to the Process Trenches ceased in December 1994. Because the Process Trenches received hazardous waste after 1980, the trenches are a RCRA disposal site. RCRA closure information is provided in Modification B of the Hanford RCRA Facility-Wide Permit and the 300 Area Process Trenches Modified Closure/Postclosure Plan (DOE-RL 1995a).

The Process Sewers transferred liquid process wastes to the South and North Process Ponds and the Process Trenches. Only those portions of the process sewer system within the operable unit (i.e., east of the railroad bed) are within the scope of this sampling and analysis plan (SAP). The system is constructed of vitreous clay pipe; the trunk sewer diameter is $61 \mathrm{~cm}$ (24 in.)

(DOE-RL 1995b). The original process sewer serving the South Process Pond was later modified to serve the North Process Pond. The process sewers were further modified to serve the Process Trenches and the 307 Retention Basins (within the 300-FF-2 Operable Unit). The portion of the process sewers serving the North and South Process Ponds were reportedly abandoned in March 1975. However, documentation of abandonment exists for only the pipe that fed the southwest corner of the South Process Pond. The method of abandonment has not been identified for the pipe that fed the northwest corner of the South Process Pond or for the pipe to the North Process Pond (Young et al. 1990).

The Ash Pits received fly ash from the 300 Area Power Plant. Surface samples from the Ash Pits were analyzed during the remedial investigation ( $\mathrm{RI}$ ), and metals concentrations below cleanup standards were detected. The Ash Pits were built over part of the South Process Pond, and contaminated soil and/or sludge from the pond operations may be present beneath the fly ash.

The Filter Backwash Pond and Retired Filter Backwash Pond received filter backwash from the 300 Area Water Treatment Plant. The Retired Filter Backwash Pond was formerly part of the South Process Pond and may contain contaminated soil and/or sludge from the pond operations. The Filter Backwash Pond was constructed in 1987 to receive filter backwash. Before 1951, this area was part of the South Process Pond. The Filter Backwash Pond was modified in the early 1990 's to include a concrete and synthetic liner.

The Sanitary Tile Field and Trenches and other sanitary system components received sewage from the 300 Area facilities. Based on process knowledge, a surface radiation survey, and RI data, these sites do not require remediation. 


\section{DOE/RL-96-70}

Rev. 0

\section{I.1.2 BURIAL GROUND AND LANDFILLS}

The 618-4 Burial Ground operated from 1955 to 1961 and received a variety of radioactive and nonradioactive solid wastes. The RIs included excavating two test pits, a surface radiation survey, and a soil gas survey. Metal objects, uranium-contaminated materials, solid wastes, and small amounts of organic soil contamination (perchloroethene and trichloroethene) were found during the RI. The baseline risk assessment showed that the perchloroethene and trichloroethene contributed insignificant risks compared to the risk from uranium (DOE-RL 1993b); therefore, these compounds are not COCs. Soil contamination with uranium up to $4,200 \mathrm{pCi} / \mathrm{g}$ was found in this burial ground.

Landfills la, 1b, 1c, and 1d received solid waste and construction debris, some of which is radioactively contaminated. Surface radiation surveys and ground penetrating radar (GPR) surveys were performed over each of the landfill areas. Contaminated surface debris was removed at Landfill $1 \mathrm{c}$ during the $\mathrm{RI}$, followed by an additional surface radiation survey and GPR survey. These data suggest that no further action is necessary at Landfill $1 \mathrm{c}$. Contaminated debris was found on the surface of Landfills $1 \mathrm{a}, 1 \mathrm{~b}$, and $1 \mathrm{~d}$, which were stabilized in place. Contamination at Landfill $\mathrm{lb}$ is expected to be similar to the North Process Pond. Landfills la and $1 \mathrm{~d}$ are expected to contain miscellaneous contaminated laboratory waste and metallic debris based on process knowledge, GPR data, and visual observation of the landfill surface areas. Landfill $1 \mathrm{~d}$ was identified as a relatively large burn pit that was used while the 618-5 Burial Ground was allowed to cool after burning debris. The GPR data indicate the presence of significant quantities of buried metal in Landfill ld.

The Aluminum Hydroxide Site (300-3) was identified during installation of a sump pit for the 300 Area Treated Effluent Disposal Facility. The site consists of several horizontal 0.3- to $0.45-\mathrm{m}$ - (1- to $1.5-\mathrm{ft}$ ) diameter cedar logs forming a vertical wall approximately $3 \mathrm{~m}(10 \mathrm{ft})$ high running in a north-south direction. The top part of the wall slopes downward to the west and the bottom part is vertical. The structure appears to be resting on a concrete slab at a depth of approximately 3 to $4.5 \mathrm{~m}$ (10 to $15 \mathrm{ft}$ ). A white chalky material was found during the excavation. The material was determined to be aluminum hydroxide, and toxic characteristic leaching procedure analysis indicated that the material was nonregulated. The material was determined to be nonhazardous and was left in place at the site.

\section{I.1.3 SURFACE RADIATION AREAS}

In addition to the postings at the waste sites, there are several posted surface radiation areas adjacent to the waste sites within the 300-FF-1 Operable Unit that are shown in Figure 2-3. Details of the surface radiation areas are provided in Teel and Olsen (1990). Two surface radiation areas along the west side of the Process Trenches (including the 300-10 aluminum shavings area) are within the 300-FF-2 Operable Unit but are adjacent to the planned remediation facilities area (see Figure 2-3). 
DOE/RL-96-70

Rev. 0

\section{I.2.0 CONTAMINANTS OF CONCERN AND CLEANUP LEVELS}

The COCs and maximum values detected within the 300-FF-1 Operable Unit are shown in Table C-1. The cleanup levels shown on this table are derived from the ROD (EPA 1996). An exposure assessment model [residual radioactivity (RESRAD)] is used to convert between soil concentrations ( $\mathrm{pCi} / \mathrm{g}$ ) and dose levels (mrem/yr). For example, in $300-\mathrm{FF}-1$, the $15-\mathrm{mrem} / \mathrm{yr}$ dose from total uranium-234, uranium-235, and uranium-238 equates to $350 \mathrm{pCi} / \mathrm{g}$.

\section{I.3.0 REMEDIATION ACTIVITIES}

The selected remedy for the 300-FF-1 Operable Unit includes selective excavation and disposal of contaminated soil and debris from the process waste units and excavation and removal of the 618-4 Burial Ground. Soil and debris from the process waste units and the 618-4 Burial Ground that are contaminated with radionuclides that would result in a $15-\mathrm{mrem} / \mathrm{yr}$ dose above background or other hazardous constituents above MTCA Method C, "Soil Cleanup Standards for Industrial Sites" (WAC 173-340-745), standards will be removed and disposed of in the Environmental Restoration Disposal Facility (ERDF). Note that the MTCA Method C cleanup values as updated in February 1996 will be used for this project (Ecology 1996). Remediation activities will include soil excavation, segregation, storage, transportation, disposal at ERDF, and site restoration.

\section{I.4.0 SAMPLING AND ANALYTICAL STRATEGIES}

Based on the existing analytical data and process knowledge, the individual process waste sites can be divided into three zones: (1) areas where the data show that the soil is above cleanup levels, (2) areas where the data show the soil is below cleanup levels, and (3) areas where the data are inconclusive. The locations of these three zones are shown in Figure C-2.

Implementation of the selected remedy will remove soil and debris from the areas that are known to be above cleanup levels with little sampling and analysis except for confirming that all contaminated soil has been removed. Areas that are already below the cleanup levels would be left in place. In-process screening and verification sampling would be conducted in these areas to confirm that all COCs are below cleanup levels. The areas where the data are inconclusive would require field analyses to determine whether the soil was contaminated above cleanup levels and needs to be removed. Verification sampling will then be conducted to confirm that all waste sites are below cleanup levels. 
DOE/RL-96-70

Rev. 0

Figure C-2. 300-FF-1 Operable Unit Cleanup Zones.

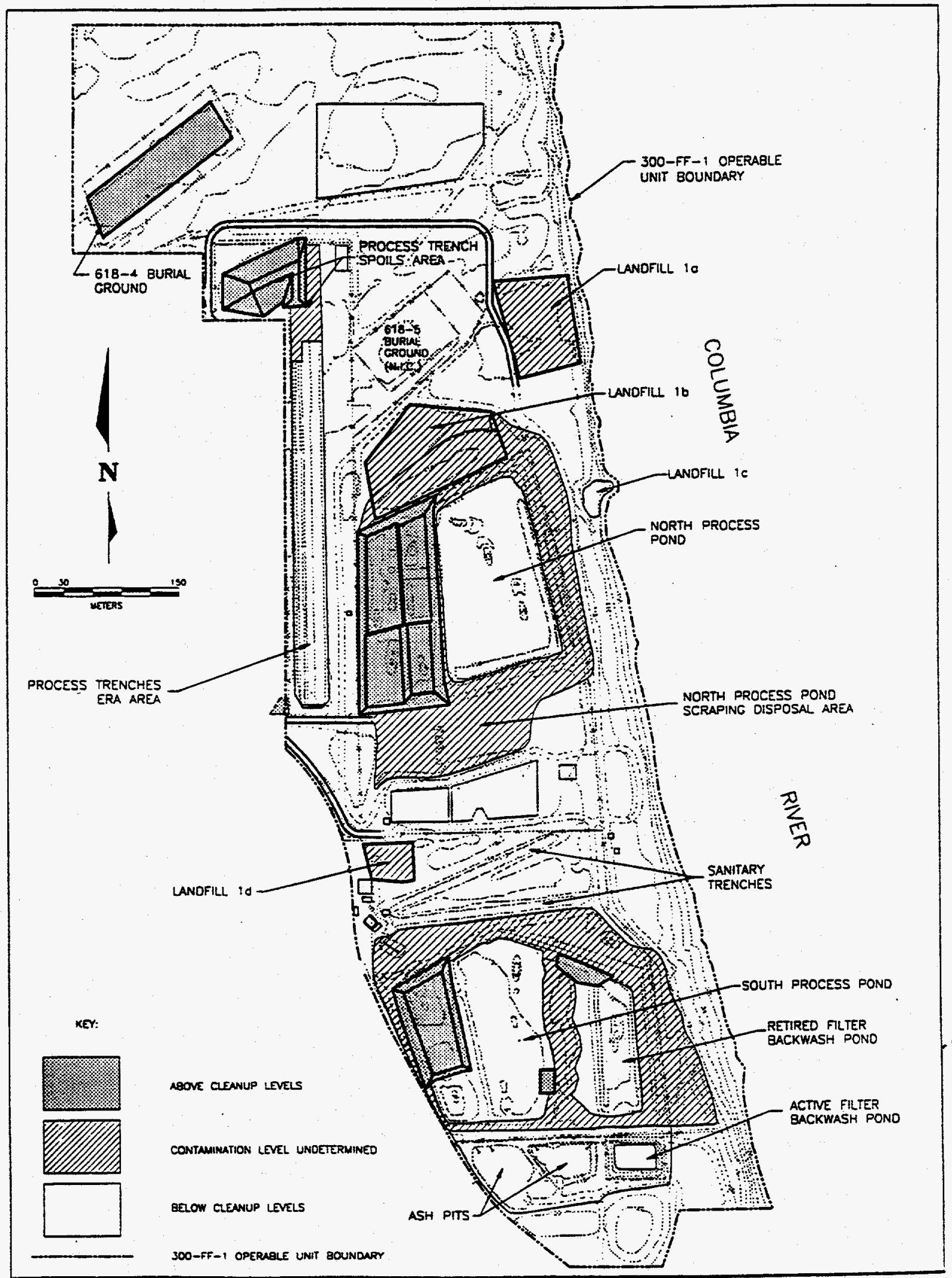

C:\SGH $\backslash 9642032 \backslash 001 \backslash 0001 \backslash 62516 R 0 A$

7-23-96 8:42 Xff: NONE

$\mathrm{C}-17$ 
Based on a qualitative evaluation of the analytical data, the removal of uranium above the cleanup standard of $350 \mathrm{pCi} / \mathrm{g}$ will likely remove the chemical COCs to below the MTCA Method $\mathrm{C}$ cleanup standards such that uranium can be used for in-process screening during remediation for all COCs. This field screening will also be used to support verification that the cleanup levels have been met at all waste sites (except for the Process Trenches), which will be verified by sampling and analysis of the remaining soils for all COCs. Present data indicate that once total uranium above the cleanup level is removed, the average concentrations of total uranium and cobalt 60 will be such that the dose will not exceed $15 \mathrm{mrem} / \mathrm{yr}$. If verification sampling unexpectedly indicates that the $15-\mathrm{mrem} / \mathrm{yr}$ cleanup level is exceeded, institutional controls may be used to allow the cobalt-60 to decay, because it has a short 5.26-year half-life.

Waste profiles for each waste site will be prepared based on the RI data and process knowledge in accordance with the ERDF waste acceptance criteria (BHI 1996b). The in-process radiation screening will be used at all waste sites to confirm that the wastes are within the waste profile ranges. At the landfills and the 618-4 Burial Ground, field screening for metals and organics will also be used to confirm that the wastes are within the waste profile ranges.

Sampling and analytical strategies are presented in Sections I.4.1 through I.4.7 for the following seven groups:

$\begin{array}{ll}- & \text { In-process screening } \\ - & \text { Disposal } \\ - & \text { Decontamination } \\ \text { - } & \text { Overburden } \\ \text { - } & \text { Verification } \\ & \text { Backfill } \\ & \text { Debris and structures. }\end{array}$

These groups are based on their common elements of similar media, sampling objectives, and associated activities.

\section{I.4.1 IN-PROCESS SCREENING}

The objectives for sampling and analysis during the excavation process are to provide ongoing guidance with regard to the extent of excavation and for waste confirmation information for disposal in ERDF. In the areas where the existing data show that the soil is above cleanup levels (Figure C-2), Environmental Restoration Contractor (ERC) personnel will conduct in-process screening for uranium over the surface before excavation and after excavation of each lift using a portable survey instrument with a sodium iodide detector connected to a backpack Global Positioning System (GPS). Although testing of a possible instrument to be used for conducting the in-process screening is underway, the technical specifications for the survey system have been developed as follows. 
- The minimum detectable activity (MDA) for the survey system must be able to see and identify soil contamination at a minimum of $50 \mathrm{pCi} / \mathrm{g}$ of uranium in the top layer ( $2.5 \mathrm{~cm}$ [1 in.]) of soil. This MDA is low enough ( $<50 \%$ of the "looked-for" activity as suggested in the U.S. Department of Energy (DOE) draft manual on releasing outdoor sites) to provide assurance that there is little chance that an area with greater than the cleanup level of $350-\mathrm{pCi} / \mathrm{g}$ uranium would be missed, but is high enough to be seen above natural background (about $1.5 \mathrm{pCi} / \mathrm{g}$ for uranium and 15 to $20 \mathrm{pCi} / \mathrm{g}$ for potassium-40).

- The survey system must provide at least a $90 \%$ confidence level that the residual radioactivity will be detected when present. This can be achieved by balancing scan speed, background readings, and instrument efficiency.

- The system must be made up of components that are readily available and have a proven record of performance under expected environmental conditions.

- The system must be able to identify to the Radiological Control Technician (RCT) when residual radioactivity is found that equals or exceeds the cleanup level. The use of the GPS is beneficial if survey result maps can be economically produced on a daily basis, although the survey instrument must continue to function even if the GPS fails. Use of the GPS to produce maps of the survey area will aid the remedial action subcontractor (RAS) in planning excavations.

- The readings recorded on the survey system (in counts per minute) must be able to equate to the residual activity (in $\mathrm{pCi} / \mathrm{g}$ ). This can be accomplished by making several field sources from the soils to be remediated and testing them in an analytical laboratory to quantify the level of radioactivity in each sample. Standards should be made for 50 , $100,350,1,000$, and if possible, $5,000 \mathrm{pCi} / \mathrm{g}$. These sources can also be used to determine the depth to which the survey system can detect a certain level of radioactivity and can be used to train RCTs on survey techniques.

- The system should be easy to carry by one RCT and not create ergonomic problems.

- The survey system must be able to reduce the interference by background radiation.

- $\quad$ The scan rate to support the MDA must be fast enough that no more than 2 hours of survey time is required to scan an area of about 0.2 hectare ( $1 / 2$ acre).

- It is preferable that the readout on the survey instrument for the radiation present shows up as mid-scale for the equivalent of $350 \mathrm{pCi} / \mathrm{g}$ uranium.

Because the scan rate of this system is approximately 4 hours per 0.4 hectare ( 1 acre), it will be able to rapidly identify areas within the waste sites that are above cleanup levels, which will be used by the RAS to plan the excavation and removal of subsequent soil lifts or "hot spot" areas. 
In areas where the existing data are inconclusive, in-process screening will be used to survey the soils excavated from test trenches and test pits by the RAS, and may include sidewall soil surveys. This information will be evaluated to determine what portion of these areas may require cleanup, as well as the excavation limits and depths. Following the excavation of these areas, subsequent surveying will be conducted to determine if subsequent soil lifts or "hot spot" areas need to be excavated.

The areas that are already below the cleanup levels would be left in place. These areas will be surveyed using the in-process screening system to confirm that the radioactive contaminants are below the cleanup levels. After confirmation that the radioactive contaminants are below cleanup levels, field-screening surveys for metals [by x-ray fluorescence (XRF)] and volatile organic compounds (VOCs) [by organic vapor monitor (OVM) and organic vapor analyzer (OVA)] will be conducted at final excavation grade before collection of final verification samples to ensure that these COCs are below cleanup levels. Verification sampling would then be conducted in these areas to confirm that all COCs are below cleanup levels, as described in Section I.4.5.

After in-process screening data indicate that radioactive contaminants are below cleanup levels, field-screening surveys for metals and VOCs will be performed at final excavation grade to ensure that these COCs are below cleanup levels. Verification sampling would then be conducted in these areas to confirm that all COCs are below cleanup levels, as described in Section 1.4.5. In addition, during excavation of the landfills and the 618-4 Burial Ground, field screening for organics and metals will be performed as indicated in Section I.4.0.

The nature of chemical contaminants and the problems inherent in detecting them in the field require that field screening be carried out in a qualitative sense to locate anomalous areas of metal or VOC contamination. Field screening for metals and VOCs will be conducted in a qualitative sense using field instruments. These include a portable isotope-source XRF spectrometer for metals and portable photoionization detectors (PIDs) and/or flame ionization detectors (FIDs) for VOCs.

The XRF is capable of detecting metals from titanium to uranium in the periodic table. Sensitivity varies from about 100 to $1,000 \mathrm{ppm}$, depending on the difference between the source energy level and the elemental absorption edge, and matrix or interelement effects. The XRF will be operated in a qualitative mode, which compares gross count rates to average values for Hanford background soils and reports results in terms of deviation from background values. This approach is discussed in McCain (1994). With qualitative XRF, it should be possible to identify areas of anomalous heavy metal concentration, and to identify specific elements based on spectral evaluation. The XRF is capable of in situ or sample measurement and is not significantly affected by adverse weather conditions.

PID and FIDs both respond to common organic compounds. A PID is effective for many common fuel and solvent compounds, while an FID responds well to most carbon-containing compounds. The most common PID in use at the Hanford Site is the Thermo Environmental 
OVM. The most common FID is the Foxboro OVA. Both instruments report results in terms of total organic concentration and do not discriminate between compounds. For either instrument, the response depends on the nature of the compound(s) involved, particularly the tendency to partition into the vapor phase. To the extent that cold weather reduces vapor pressure and inhibits volatilization (and increases relative humidity in the case of the OVM), the performance of these instruments may be somewhat temperature-dependent. The use of OVMs and OVAs to screen for VOCs is discussed in EPA (1990).

\section{I.4.2 DISPOSAL}

Waste profiles for each waste site will be prepared based on the RI data and process knowledge in accordance with the ERDF waste acceptance criteria (BHI 1996b). The in-process radiation screening will be used at all waste sites to confirm that the wastes are within the waste profile ranges. At the landfills and the 618-4 Burial Ground, field screening for metals and organics will also be used to confirm that the wastes are within the waste profile ranges. Additional profiling of waste materials may be necessary if excavation of Landfills $1 \mathrm{a}, 1 \mathrm{~b}, 1 \mathrm{~d}$, and the 618-4 Burial Ground uncovers containers that contain liquids, greater than Class $C$ radioactive material, friable asbestos, or other unacceptable materials not provided for in the waste profile. The need for, and type of, additional profiling to be performed for such waste materials will be evaluated by the ERC on a case-by-case basis.

\section{I.4.3 DECONTAMINATION}

Water used in the RAS decontamination facility will drain to holding tanks. This water can be applied to areas above cleanup levels as a dust suppressant (i.e., by spraying) without sampling and analysis as long as these areas are still being excavated. When there are no areas above cleanup levels left onsite, and one tank reaches approximately three-quarters full, a grab sample of the supernatant liquid will be collected by ERC personnel and submitted for laboratory analysis. After sampling, no more liquid can be added to the tank, and the decontamination water will be diverted to the second tank. If the supernatant results are below the purgewater acceptance standards used for onsite disposal of monitoring well purgewater (WHC 1990), the RAS can spray the water within the disturbed areas onsite (i.e., as a dust suppressant). If the supernatant results are above the purgewater acceptance standards, the water must be transported to the 200 Area Effluent Treatment Facility for treatment and disposal.

After the project is completed, the decontamination tanks will be excavated and removed during demobilization activities. Laboratory samples will be taken under the tank(s) if there is any evidence of leakage and laboratory analysis of decontamination tank water ever resulted in the purgewater criteria being exceeded. 
Rev. 0

\section{I.4.4 OVERBURDEN}

Overburden is material previously placed on top of a waste site. The objective for sampling and analysis of overburden is to verify that these uppermost soils do not contain COCs above cleanup levels so that this material can be removed and stockpiled onsite for reuse in regrading the waste site. The strategy for sampling and analysis of overburden is to conduct in-process screening to verify that radioactive contaminants are below cleanup levels and, if confirmed, conduct field screening for metals and VOCs before verification sampling (see Section 1.4.5). If either sampling strategy detects areas above cleanup levels, these soils will be excavated and sent to ERDF for disposal.

\section{I.4.5 VERFFICATION}

When the in-process screening and the field screening for metals and VOCs indicates that a waste site or waste site subarea (i.e., settling basins subarea and infiltration basin subarea of the North Process Pond) is below cleanup levels, verification sampling and analyses will be conducted to verify that the remaining soils do not contain COCs above the cleanup levels. All verification samples will be analyzed by an offsite analytical laboratory that is state-accredited for water samples, because the state does not give accreditation specifically for soils.

An evaluation of the existing data from each waste site was conducted using the Statistical Methods for Evaluating the Attainment of Superfund Cleanup Standards, Volume 1: Soils and Solid Media (EPA 1987) to help establish the number of samples needed to meet the regulators objectives and the Washington State Department of Ecology Toxics Cleanup Program Statistical Guidance for Ecology Site Manage (Ecology 1992) to evaluate attainment of cleanup standards to MTCA Method C, "Industrial Cleanup Values for Soils" (WAC 173-340745). Because each waste site already has a number of existing soil results that indicate the soils to be left in place will be below the cleanup levels, and the mean of this data for each contaminant is well below the $\mathrm{COC}$ cleanup levels, this evaluation indicated that most waste sites would only require one or two samples to verify that cleanup levels have been achieved. A notable exception is the South Process Pond where, because of the presence of cobalt- 60 near the cleanup level, 13 samples will be needed within the areas known to be above cleanup levels and 19 samples will be needed within the areas below cleanup levels in order to verify that cleanup levels have been achieved.

Although the statistical evaluation indicates that only a small number (e.g., one or two) of samples would be required to confirm cleanup in most waste sites, it is impossible to create population distributions with only one sample. The minimum number of samples per waste site or waste site subarea to provide a one-sided $95 \%$ upper confidence limit (UCL) on the geometric mean concentration of each $\mathrm{COC}$ (if the data distribution is lognormal) was identified as six 
$(n=6)$ for all but the South Process Pond (see above). These samples would be collected from the surface soils using a stratified simple random method following the sample coordinate selection method described in Section 5.2 of Methods for Evaluating the Attainment of Cleanup Standards (EPA 1989).

The samples would be submitted for analysis of all COCs, as detailed in Part II of this SAP.

\section{I.4.6 BACKFILL}

One goal of the 300-FF-1 remediation is to regrade the waste site slopes without using any imported backfill. Onsite backfill will come from overburden that has been previously sampled and analyzed as described in Section 1.4.4, from perimeter and interior dikes of the North and South Process Ponds and Process Trenches that have been verified as being below cleanup levels as described in Section 1.4.5, and from the soil stockpile area south of the Ash Pits and Filter Backwash Pond. Before use of this stockpile for backfill, a surface radiation survey will be conducted and six soil samples of the soil stockpile area will be randomly sampled by ERC personnel with the help of RAS personnel and equipment to excavate and obtain samples from the interior of the pile at depths up to 3 to $4.5 \mathrm{~m}$ ( 10 to $15 \mathrm{ft}$ ). These samples will be submitted for verification analyses of all COCs as detailed in Part II.

If imported backfill is needed to regrade parts of the site, it shall be obtained from noncontaminated borrow sources as approved by the ERC.

\section{I.4.7 DEBRIS AND STRUCTURES}

Debris and structures include items such as metallic objects, old bird screens, concrete lids, wood and timber pieces, abandoned telephone poles, fencing and fenceposts, concrete structures, the small blockhouse on the east side of the Process Trenches, and process piping. Field screening in Landfills la, lb, 1d, and the 618-4 Burial Ground is discussed in Section 1.4.2. Debris that may have been incidental to the operation of the waste sites (e.g., fences, telephone poles, bird screens) and the exposed ends of process piping will be surveyed for radiation by ERC personnel using standard equipment. Debris found within the landfills or the 618-4 Burial Ground will be evaluated by ERC personnel during excavation and passing of the debris through a grizzly screen to identify wastes that may not be acceptable to ERDF. The need for, and type of, additional characterization to be performed for debris and structures will be evaluated by the ERC on a case-by-case basis. The ERC may direct the RAS to discontinue use of the grizzly if there is no apparent value in its use. This requires concurrence of the DOE, the U.S. Environmental 
Rev. 0

Protection Agency (EPA), and the Washington State Department of Ecology (Ecology). Prior to waste site regrading and restoration, the ERC will conduct radiation surveys of the fencing around each waste site. Radiation surveys will also have been completed for any materials placed in the Reusable Material Storage Area (see Figure 2-3 for location). Only materials meeting site release criteria, as established in Hanford Site Radiological Control Manual (HSRCM 1994), will be placed in this area. The ERC will determine which components placed in this area can be reused or recycled. 
DOE/RL-96-70

Rev. 0

PART II

QUALITY ASSURANCE PROJECT PLAN

\section{II.1.0 INTRODUCTION}

This QAPjP presents the objectives, functional activities, methods, and quality assurance/quality control (QA/QC) procedures associated with the collection and analyses of soil samples during remedial activities in the 300-FF-1 Operable Unit. Where appropriate, existing QA/QC guidelines, policies, and programs are incorporated by reference. This QAPjP follows EPA guidelines contained in Requirements for Quality Assurance Project Plans for Environmental Data Operations (EPA 1994).

\section{II.2.0 PROJECT MANAGEMENT/DATA QUALITY OBJECTIVES}

\section{II.2.1 PROJECT/TASK ORGANIZATION}

The project/task organization for the $300-\mathrm{FF}-1$ sampling and analysis includes the regulatory agencies of EPA and Ecology, DOE, the ERC, and the RAS. A brief description of their roles and responsibilities follows.

\section{II.2.1.1 Regulatory Agencies}

The regulatory agencies for the remediation activities in the 300-FF-1 Operable Unit are EPA and Ecology. Ecology is the lead regulatory agency for the Process Trenches that are being closed under RCRA. EPA is the lead regulatory agency for all other waste units within the 300-FF-1 Operable Unit. The lead regulatory agency is responsible for overseeing the activities and ensuring that all applicable requirements are met.

\section{II.2.1.2 U.S. Department of Energy}

The DOE is the government agency responsible for the remedial actions conducted in the 300-FF-1 Operable Unit and throughout the Hanford Site. The DOE project manager is responsible for the management of their assigned activities, including scope, budget, schedule, quality, personnel, communication, risk/safety, contracts, and regulatory interface. 
DOE/RL-96-70

Rev. 0

\section{II.2.1.3 Environmental Restoration Contractor}

The ERC project team is composed of Bechtel Hanford, Inc. and its subcontractors, CH2M HILL Hanford, Inc., IT Hanford, Inc., and Thermo Hanford, Inc. The ERC project manager is the single point-of-contact for the 300-FF-1 remediation, and is responsible for developing, maintaining, and overseeing a project team composed of all required disciplines to accomplish the remedial action in a safe, efficient, and compliant manner.

\section{II.2.1.4 Remedial Action Subcontractor}

A remediated design package has been prepared by a remedial design subcontractor. The RAS is responsible for conducting the remedial action in accordance with the remedial design package and for ensuring that all work done by his lower tier subcontractors is also conducted in accordance with the remedial design package. Data generated from the sampling and analysis will be used by the RAS to plan and execute the excavation and removal actions.

\section{II.2.2 PROBLEM DEFINITION/BACKGROUND}

Problem definition/background is presented in Part I of this SAP.

\section{II.2.3 QUALITY OBJECTIVES AND CRITERIA FOR MEASUREMENT DATA}

Proposed analytical parameters, data uses, and applicable detection levels for the 300-FF-1 sampling and analysis of soils are presented in Table C-2.

The QA objective of this plan is to develop implementation procedures that will provide data of known and appropriate quality. Data quality is assessed by representativeness, comparability, accuracy, precision, and completeness. Definitions of these parameters, applicable procedures, and level of effort are described below. The applicable QC procedures, quantitative target limits, and levels of effort for assessing data quality are dictated by the intended use of the data and the nature of the analytical methods. Analytical methodology and specific QC procedures are discussed in Section II.3.0. The following is a description of the data quality parameters.

Representativeness is a measure of how closely the results reflect the actual concentration or distribution of the chemical compounds in the matrix sampled. Sampling plan design, sampling techniques, and sample handling protocols (e.g., for storage, preservation, and transportation) have been developed and are discussed in subsequent sections of this SAP. The proposed documentation will establish that protocols have been followed and sample identification and integrity ensured. Field equipment blanks and field duplicates, collected at a minimum frequency of one per sampling site frequency, will be used to assess field and transport contamination and method variation. To assess laboratory contamination, laboratory method blanks will be run at a minimum frequency of $5 \%$ of the samples ( 1 in 20 samples) or at least once per batch or sample delivery group (SDG). 
DOE/RL-96-70

Rev. 0

Table C-2. Data Uses and Required Limits. (sheet 1 of 2)

\begin{tabular}{|c|c|c|}
\hline $\begin{array}{l}\text { Analytical } \\
\text { Parameter }\end{array}$ & Data Use & $\begin{array}{l}\text { Needed Detection } \\
\text { Level }^{\mathrm{a}, \mathrm{b}}\end{array}$ \\
\hline Total Uranium & $\begin{array}{ll}\text { - } & \text { In-process screening (in situ) } \\
\text { - } & \text { Overburden (in situ) }\end{array}$ & $\begin{array}{l}50 \\
50\end{array}$ \\
\hline $\begin{array}{c}\text { Arsenic } \\
\text { Barium } \\
\text { Cadmium } \\
\text { Chromium } \\
\text { Lead } \\
\text { Mercuryc }^{c} \\
\text { Selenium } \\
\text { Silver } \\
\end{array}$ & $\begin{array}{l}\text { Disposal profiling (XRF field screening) } \\
\text { In-process screening (in situ) before } \\
\text { verification }\end{array}$ & $\begin{array}{c}100 \\
2,000 \\
20 \\
100 \\
100 \\
-- \\
20 \\
20 \\
\end{array}$ \\
\hline $\begin{array}{l}\text { Volatile } \\
\text { Organic } \\
\text { Compounds }\end{array}$ & $\begin{array}{ll}\text { Disposal profiling (OVM/OVA field } \\
\text { screening) } \\
\text { In-process screening (in situ) before } \\
\text { verification }\end{array}$ & $\begin{array}{l}5 \mathrm{ppb} \text { above } \\
\text { background }\end{array}$ \\
\hline Uranium-234 & $\begin{array}{ll}- & \text { Overburden (off location) } \\
\text { - } & \text { Verification (off location) } \\
\text { Backfill (off location) }\end{array}$ & $\begin{array}{l}1 \\
1 \\
1\end{array}$ \\
\hline Uranium-235 & $\begin{array}{ll}\text { Overburden (off location) } \\
\text { Verification (off location) } \\
\text { Backfill (off location) }\end{array}$ & $\begin{array}{l}1 \\
1 \\
1\end{array}$ \\
\hline Uranium-238 & $\begin{array}{ll} & \text { Overburden ( off location) } \\
- & \text { Verification (off location) } \\
- & \text { Backfill (off location) } \\
\end{array}$ & $\begin{array}{l}1 \\
1 \\
1\end{array}$ \\
\hline Cobalt -60 & $\begin{array}{ll}- & \text { Overburden (off location) } \\
\text { - } & \text { Verification (off location) } \\
\text { Backfill (off location) }\end{array}$ & $\begin{array}{l}1 \\
1 \\
1\end{array}$ \\
\hline Arsenic & $\begin{array}{ll}- & \text { Overburden (off location) } \\
- & \text { Verification (off location) } \\
& \text { Backfill (off location) } \\
\end{array}$ & $\begin{array}{l}10 \\
10 \\
10\end{array}$ \\
\hline $\begin{array}{l}\text { Benzo(a)- } \\
\text { pyrene }\end{array}$ & $\begin{array}{ll} & \text { Overburden (off location) } \\
- & \text { Verification (off location) } \\
- & \text { Backfill (off location) } \\
\end{array}$ & $\begin{array}{l}0.5 \\
0.5 \\
0.5 \\
\end{array}$ \\
\hline Chrysene & $\begin{array}{ll}- & \text { Overburden (off location) } \\
\text { - } & \text { Verification (off location) } \\
\text { Backfill (off location) }\end{array}$ & $\begin{array}{l}0.5 \\
0.5 \\
0.5\end{array}$ \\
\hline
\end{tabular}


DOE/RL-96-70

Rev. 0

Table C-2. Data Uses and Required Limits. (sheet 2 of 2)

\begin{tabular}{|c|c|c|}
\hline $\begin{array}{l}\text { Analytical } \\
\text { Parameter }\end{array}$ & Data Use & $\begin{array}{c}\text { Needed Detection } \\
\text { Level }^{\mathrm{a}, \mathrm{b}}\end{array}$ \\
\hline $\begin{array}{l}\text { Polychlorinated } \\
\text { biphenyls }\end{array}$ & $\begin{array}{ll}- & \text { Overburden (off location) } \\
- & \text { Verification (off location) } \\
- & \text { Backfill (off location) } \\
\end{array}$ & $\begin{array}{l}1 \\
1 \\
1\end{array}$ \\
\hline Thallium & $\begin{array}{ll}- & \text { Overburden (off location) } \\
- & \text { Verification (off location) } \\
- & \text { Backfill (off location) } \\
\end{array}$ & $\begin{array}{l}20 \\
20 \\
20\end{array}$ \\
\hline \multicolumn{3}{|c|}{$\begin{array}{l}{ }^{2} \mathrm{pCi} / \mathrm{g} \text { for radionuclides, } \mathrm{mg} / \mathrm{kg} \text { for other constituents. } \\
\text { bNeeded detection levels are to meet Record of Decision cleanup levels. } \\
\text { 'Screening for mercury to field XRF capability. } \\
\text { dOff location analysis is analysis at an offsite laboratory. } \\
\text { OVA = organic vapor analyzer } \\
\text { OVM = organic vapor monitor } \\
\text { XRF }=\text { x-ray fluorescence }\end{array}$} \\
\hline
\end{tabular}


Rev. 0

Comparability expresses the confidence with which one data set can be compared to another. Data comparability will be maintained using standard procedures when available and consistent methods and units. Table C-3 lists specific parameters and applicable methods for analytes and target detection limits of soils, and Table C-4 provides this information for water. Actual detection limits will depend on the sample matrix and will be reported as defined for the specific samples.

Accuracy is an assessment of the closeness of the measured value to the true value. Accuracy of chemical test results is assessed by spiking samples with known standards and establishing the average recovery. For a matrix spike, known amounts of a standard compound identical to the compounds being measured are added to the sample. For some radionuclide measurements, method calibrations against known standards are used to establish accuracy.

A quantitative definition of average recovery (accuracy) is given in Section II.5.3. Accuracy measurement will be carried out with a minimum frequency of 1 in 20 samples analyzed or at least once per SDG. Target quantitative accuracy objectives are listed as applicable in Table C-3 for soils and in Table C-4 for water.

Precision is a measure of the data spread when more than one measurement has taken on the same sample. Precision can be expressed as the relative percent difference for duplicate measurements. A quantitative definition of the relative percent difference is given in Section II.5.3. The level of effort for precision measurements will be a minimum of 1 in 20 samples or at least once per SDG.

Completeness is a measure of the amount of valid data obtained from the analytical measurement system and the complete implementation of defined field procedures. The quantitative definition of completeness is given in Section II.5.3. The target completeness objectives for soils and water are listed in Tables $\mathrm{C}-3$ and C-4, respectively.

\section{II.2.4 PROJECT NARRATIVE}

The following is a list of objectives and the associated methods (incorporated by reference) to achieve that objective:

- Determining the success (quantitatively or qualitatively) of the project or task by methods defined in Section II.2.3

- Determining design requirements and description (Section II.3.1)

- $\quad$ Determining sample type and sampling location requirements (Section III.2.0)

- Determining sample handling and custody requirements (Section III.5.0) 
Rev. 0

Table C-3. Data Quality Objectives for Soils.

\begin{tabular}{|c|c|c|c|c|c|c|}
\hline $\begin{array}{l}\text { Analytical } \\
\text { Parameter }\end{array}$ & $\begin{array}{l}\text { Analytical } \\
\text { Method }\end{array}$ & $\begin{array}{l}\text { Target } \\
\text { Detection } \\
\text { Limit }\end{array}$ & $\begin{array}{l}\text { Accuracy } \\
\text { (LCS \% } \\
\text { RCVY) }\end{array}$ & \begin{tabular}{|c} 
Accuracy $^{a}$ \\
(Spike \\
Sample \\
\%RCVY) \\
\end{tabular} & $\begin{array}{c}\text { Precision }^{b} \\
\text { (RPD) }\end{array}$ & $\begin{array}{c}\text { Completeness } \\
(\%)\end{array}$ \\
\hline${ }^{234} \mathrm{U}$ & EPA EMSL 0539-17 & $1 \mathrm{p}$ & 30 & $\pm 3 \sigma^{a}$ & 35 & 90 \\
\hline${ }^{235} \mathrm{U}$ & EPA EMSL 0539-17 & $1 \mathrm{pCi} / \mathrm{g}$ & $70-130$ & $\pm 3 \sigma^{2}$ & 35 & 90 \\
\hline${ }^{238} \mathrm{U}$ & EPA EMSL 0539-17 & $1 \mathrm{pCi} / \mathrm{g}$ & $70-130$ & $\pm 3 \sigma^{2}$ & 35 & 90 \\
\hline${ }^{60} \mathrm{Co}$ & EPA & $1 \mathrm{pCi} / \mathrm{g}$ & & $\pm 3 \sigma^{a}$ & 3 & 0 \\
\hline Arsenic & EPA $3050 / 6010 \mathrm{~A}$ & $10 \mathrm{mg} / \mathrm{kg}$ & & $75-125$ & 35 & 90 \\
\hline $\begin{array}{l}\text { Benzo(a) } \\
\text { pyrene }\end{array}$ & EPA 35 & $5 \mathrm{mg} / \mathrm{kg}$ & $35-140^{c}$ & $35-140$ & 35 & 90 \\
\hline Chrysene & PA 3550/8270 & $0.5 \mathrm{mg} / \mathrm{kg}$ & & $35-140$ & 2 & 0 \\
\hline $\mathrm{PCBs}$ & EPA $3550 / 8080$ & $1 \mathrm{mg} / \mathrm{kg}$ & $35-140^{c}$ & $35-140$ & 35 & 90 \\
\hline Thallium & EPA $3050 / 6010 A$ & $20 \mathrm{mg} / \mathrm{kg}$ & $80-120$ & $75-125$ & 35 & 90 \\
\hline \multicolumn{7}{|c|}{$\begin{array}{l}{ }^{2} \text { Accuracy criterion is expressed by measurement statistics in the absence of sample matrix sp } \\
\text { analysis. In the absence of matrix spike analysis, a laboratory control sample will be evaluate } \\
\text { and the result should fall within } 70 \% \text { to } 130 \% \text { of the true value for the data to be considered } \\
\text { adequately accurate. A matrix spike analysis is optional for determination using alpha } \\
\text { spectrometry. If a matrix spike is performed using this technique, the result should fall withit } \\
60 \% \text { to } 140 \% \text { of the true value for the data to be considered adequately accurate. } \\
\text { bPrecision criterion is for concentrations greater than five times the target detection limit. } \\
\text { Precision criterion for concentrations less than five times the target detection limit is plus or } \\
\text { minus two times the target detection limit. }\end{array}$} \\
\hline \multicolumn{7}{|c|}{$\begin{array}{l}\text { 'Accuracy criteria for organic parameters may be evaluated on laboratory control sample results } \\
\text { if accuracy criteria using matrix spike cannot be met. }\end{array}$} \\
\hline $\begin{array}{l}\mathrm{LCS}= \\
\mathrm{PCB}= \\
\mathrm{RCVY}= \\
\mathrm{RPD}=\end{array}$ & $\begin{array}{l}\text { oratory control san } \\
\text { ychlorinated biphe } \\
\text { overy } \\
\text { ative percent differ }\end{array}$ & & & & & \\
\hline
\end{tabular}


Table C-4. Data Quality Objectives for Water.

\begin{tabular}{|c|c|c|c|c|c|c|}
\hline $\begin{array}{l}\text { Analytical } \\
\text { Parameter }\end{array}$ & $\begin{array}{l}\text { Analytical } \\
\text { Method }\end{array}$ & $\begin{array}{l}\text { Onsite } \\
\text { Disposal } \\
\text { Limit }^{\mathrm{a}} \\
\end{array}$ & $\begin{array}{c}\text { Target } \\
\text { Detection } \\
\text { Limit }^{\mathbf{a}} \\
\end{array}$ & $\begin{array}{l}\text { Accuracy } \\
\text { (Spike \% } \\
\text { Recovery) } \\
\end{array}$ & $\begin{array}{l}\text { Precision } \\
\text { (RPD) }\end{array}$ & $\begin{array}{l}\text { Complete- } \\
\text { ness } \\
(\%) \\
\end{array}$ \\
\hline \multicolumn{7}{|c|}{ METALS } \\
\hline Aluminum & EPA $6010 \mathrm{~A}$ & $\mathrm{NA}$ & 200 & $80-120$ & $<20 \%$ & 90 \\
\hline Antimony & EPA 6010A & 16,000 & 100 & $80-120$ & $<20 \%$ & 90 \\
\hline Arsenic & EPA 6010A & 480 & 5 & $80-120$ & $<20 \%$ & 90 \\
\hline Beryllium & EPA 6010A & 53 & 5 & $80-120$ & $<20 \%$ & 90 \\
\hline Cadmium & EPA $6010 \mathrm{~A}$ & 11 & 2 & $80-120$ & $<20 \%$ & 90 \\
\hline Chromium & EPA $6010 \mathrm{~A}$ & 110 & 10 & $80-120$ & $<20 \%$ & 90 \\
\hline Copper & EPA $6010 \mathrm{~A}$ & 120 & 10 & $80-120$ & $<20 \%$ & 90 \\
\hline Iron & EPA $6010 A$ & 3,000 & 30 & $80-120$ & $<20 \%$ & 90 \\
\hline Lead & EPA 7421 & 32 & 5 & $80-120$ & $<20 \%$ & 90 \\
\hline Manganese & EPA $6010 \mathrm{~A}$ & 500 & 5 & $80-120$ & $<20 \%$ & 90 \\
\hline Mercury & EPA 7470 & 0.1 & 0.1 & $80-120$ & $<20 \%$ & 90 \\
\hline Nickel & EPA $6010 \mathrm{~A}$ & 1,600 & 10 & $80-120$ & $<20 \%$ & 90 \\
\hline Silver & EPA $6010 \mathrm{~A}$ & 10 & 10 & $80-120$ & $<20 \%$ & 90 \\
\hline Uranium & EPA 908.1 & 590 & 0.7 & $70-130$ & $<20 \%$ & 90 \\
\hline Zinc & EPA 6010A & 1,100 & 5 & $80-120$ & $<20 \%$ & 90 \\
\hline \multicolumn{7}{|c|}{ ORGANICS } \\
\hline $\begin{array}{l}\text { 1,2-dichloro- } \\
\text { ethylene }\end{array}$ & EPA $8260 A$ & 70 & 10 & $80-120$ & $<20 \%$ & 90 \\
\hline $\begin{array}{c}\text { Methylene } \\
\text { chloride }\end{array}$ & EPA $8260 A$ & 10 & 10 & $80-120$ & $<20 \%$ & 90 \\
\hline $\begin{array}{l}\text { Tetrachloro- } \\
\text { ethylene }\end{array}$ & EPA $8260 A$ & 8,400 & 5 & $80-120$ & $<20 \%$ & 90 \\
\hline $\begin{array}{l}\text { Trichloro- } \\
\text { ethylene }\end{array}$ & EPA $8260 \mathrm{~A}$ & 50 & 5 & $80-120$ & $<20 \%$ & 90 \\
\hline PCBs & EPA 808 & 1 & 1 & $50-150$ & $<20 \%$ & 90 \\
\hline \multicolumn{7}{|c|}{ RADIOCHEMICAL } \\
\hline Cesium-137 & $\begin{array}{c}\text { EPA EMSL } \\
0539-17 \\
\end{array}$ & 2,000 & 20 & $70-130$ & $<20 \%$ & 90 \\
\hline Uranium & EPA 908.0 & 400 & 0.5 & $60-140$ & $<20 \%$ & 90 \\
\hline \multicolumn{7}{|c|}{$\begin{array}{l}{ }^{2} \text { Source: WHC }(1990) . \text { Metals and organics in } \mu \mathrm{g} / \mathrm{L} \text {, radiochemicals in } \mathrm{pCi} / \mathrm{L} \text {. } \\
\mathrm{NA}=\text { not applicable } \\
\mathrm{PCB}=\text { polychlorinated biphenyl } \\
\mathrm{RPD}=\text { relative percent difference }\end{array}$} \\
\hline
\end{tabular}


DOE/RL-96-70

Rev. 0

- $\quad$ Selecting analytical methods (Section II.3.2)

- Calibrating and taking performance evaluation samples for sampling and analytical methods used (Section II.3.3)

- Determining sampling or analytical instrumentation requirements (Section II.3.4)

- $\quad$ Planning for peer or readiness review before data collection (Section II.4.1)

- Maintaining ongoing assessments during actual operation (oversight) (Section II.4.1).

\section{II.2.5 SPECIAL TRAINING REQUIREMENTS/CERTIFICATION}

Training or certification requirements needed by ERC sampling personnel are described in BHI-HR-02, ERC Training Procedures. Field personnel shall have completed the following mandatory training before starting work:

- Occupational Safety and Health Administration (OSHA) 40-Hour Hazardous Waste Worker

- $\quad$ Radiation Worker

- Hanford General Employee Training [or Hanford Site Orientation if employee is a new hire]

- Hazardous Materials Employee Training (49 CFR 172, Subpart H)

- Cultural Resources Identification Training.

\section{II.3.0 MEASUREMENT/DATA ACQUISITION}

\section{II.3.1 SAMPLING PROCESS DESIGN}

The sampling process design for the sampling objectives described in Part I is described in the following sections.

\section{II.3.1.1 In-Process Screening}

The in-process screening strategy was discussed in Section I.4.1. Based on a qualitative evaluation of the analytical data, the removal of uranium above the CERCLA cleanup standard 
of $350 \mathrm{pCi} / \mathrm{g}$ will likely remove the chemical COCs to below the MTCA Method C cleanup standards such that in-process screening for uranium can be used to guide the remediation process for all COCs.

Although testing of a possible instrument to be used for this screening is currently underway, the technical specifications for this system indicate that it will be able to screen and record data from minimum of $10 \%$ of the surface of a waste unit at a rate of about 4 hours per 0.4 hectare ( 1 acre).

After confirmation that the radioactive contaminants are below cleanup levels, field screening surveys for metals (by XRF) and VOCs (by OVM and OVA) will be conducted at final excavation grade before collection of final verification samples to ensure that these COCs are below cleanup levels.

\section{II.3.1.2 Disposal}

Waste profiles for each waste site will be prepared based on the RI data and process knowledge in accordance with the ERDF waste acceptance criteria (BHI 1996b). The in-process radiation screening will be used at all waste sites to confirm that the wastes are within the waste profile ranges. At the landfills and the 618-4 Burial Ground, field screening of soils for RCRA metals and organics will also be used to confirm that the wastes are within the waste profile ranges. Metals will be analyzed using XRF, and organics will be analyzed using an OVM and an OVA. A surface grab soil sample will be collected and analyzed by XRF for a minimum of every $115 \mathrm{~m}^{3}\left(150 \mathrm{yd}^{3}\right)$ excavated. The OVM will be used to continuously monitor soils during excavation. If the OVM detects concentrations of organics greater than $5 \mathrm{ppm}$ above background, a surface grab soil sample will be collected and analyzed by OVA to help identify the organic compound. The need for, and type of, additional sampling and characterization that may be needed to identify waste materials excavated from Landfills $1 \mathrm{a}, 1 \mathrm{~b}, 1 \mathrm{~d}$, and the 618-4 Burial Ground will be evaluated by the ERC on a case-by-case basis.

\section{II.3.1.3 Decontamination}

When there are no areas above cleanup levels left onsite, and one tank reaches approximately three-quarters full, a grab sample of the supernatant liquid will be collected by ERC personnel and submitted for laboratory analysis. This sample will be analyzed for the analytes listed in Table $\mathrm{C}-4$ to determine the appropriate disposal method for this decontamination water.

\section{II.3.1.4 Overburden}

The approach for sampling and analysis of overburden is to conduct in-process screening to verify that radioactive contaminants are below cleanup levels and, if confirmed, conduct field screening for metals and VOCs before verification sampling (see Section II.3.1.5). If either sampling strategy detects areas above cleanup levels, these soils will be excavated and sent to ERDF for disposal. 
Rev. 0

\section{II.3.1.5 Verification}

A statistical evaluation was performed based on the minimum detectable difference approach presented in EPA guidance document Methods for Evaluating the Attainment of Clean-up Standards, Volume 1: Soils and Solid Media (EPA 1987). Formulae for testing data distributions using the $\mathrm{W}$ test and upper one-sided $95 \%$ confidence limit analysis for the mean of a lognormal distribution are from Washington State Department of Ecology Toxics Cleanup Program Statistical Guidance for Ecology Site Managers (Ecology 1992). Although the statistical evaluation indicated that only a small number (e.g., one or two) of samples would be required to confirm cleanup in most waste sites, it is impossible to create population distributions with only one or two samples. The minimum number of samples per waste site or waste site subarea to provide a one-sided $95 \%$ UCL on the arithmetic or geometric mean concentration of each COC (depending on the data distribution) was identified as six $(n=6)$ for all but the South Process Pond. Because of the presence and variability of cobalt- 60 concentrations near the cleanup level in the South Process Pond, 13 samples will be needed in the area above cleanup levels and 19 samples will be needed in the area below cleanup levels to confirm site cleanup. The number of verification samples to be collected from the waste sites and waste site subareas was calculated in accordance with EPA guidelines (EPA 1987), using the assumptions listed below. Verification samples will be collected from the surface soils using a stratified simple random basis. The samples will be submitted for analysis of all COCs without any compositing. A summary of the waste site and subsite contaminant distributions, means, and standard deviation is provided in Table C-5.

Verification sampling would start once the in-process screening and field screening for metals and VOCs provides reasonable confidence that the cleanup levels have been met. The Contractor's project engineer will decide when to initiate verification sampling.

The statistical method used to determine the minimum number of verification samples to be collected from all waste sites or waste site subareas requires the following specifications. First, specify the desired tolerances of false-positive and false-negative errors. Second, specify the cleanup levels. Third, the null hypothesis must be designated. Fourth, the hypothesis testing value is specified. This value is typically chosen based on region of indifferences of decision errors. Given the typical null hypothesis, it is assumed dirty until proven different; the gray region is selected as a value between $80 \%$ and $100 \%$ of the cleanup goal. Fifth, estimate the variability within the decision unit. The size of the decision unit is not explicitly included in this approach. Typically, the variability of the COC within the decision unit (ACS or BCS) will be related to the physical size of the unit; therefore, size is considered implicit. The proposed number of samples was calculated from the observed variability of the existing RI data from each subarea of each waste site. The detailed statistical calculations are documented in the 300-FF-1 DQO summary report (BHI 1996a). 
Table C-5. Waste Site/Subsite Contaminant Distribution, Mean, and Standard Deviation.

\begin{tabular}{|c|c|c|c|c|c|}
\hline Waste Site & Subsite & Contaminants & Distribution & Mean ${ }^{a b}$ & $\begin{array}{c}\text { Standard } \\
\text { Deviations }^{\mathrm{a}, \mathrm{b}}\end{array}$ \\
\hline $\begin{array}{l}\text { South Process } \\
\text { Pond }\end{array}$ & $\mathrm{BCS}$ & $\begin{array}{l}\text { Arsenic } \\
\text { Thallium } \\
\text { Cobalt- } 60 \\
\text { Total uranium } \\
\end{array}$ & $\begin{array}{l}\text { Log Normal } \\
\text { Log Normal } \\
\text { Log Normal } \\
\text { Log Normal } \\
\end{array}$ & $\begin{array}{l}2.11 \\
0.30 \\
0.22 \\
5.57 \\
\end{array}$ & $\begin{array}{l}1.54 \\
1.85 \\
5.89 \\
4.60 \\
\end{array}$ \\
\hline $\begin{array}{l}\text { South Process } \\
\text { Pond }\end{array}$ & $\mathrm{ACS}$ & $\begin{array}{l}\text { Arsenic } \\
\text { Thallium } \\
\text { Cobalt- } 60 \\
\text { Total uranium } \\
\end{array}$ & $\begin{array}{l}\text { Normal } \\
\text { Log Normal } \\
\text { Log Normal } \\
\text { Log Normal }\end{array}$ & $\begin{array}{l}1.69 \\
0.50 \\
0.16 \\
8.18 \\
\end{array}$ & $\begin{array}{l}0.61 \\
1.89 \\
4.34 \\
3.30 \\
\end{array}$ \\
\hline $\begin{array}{l}\text { North Process } \\
\text { Pond }\end{array}$ & $\mathrm{BCS}$ & $\begin{array}{l}\text { Arsenic } \\
\text { Total uranium }\end{array}$ & $\begin{array}{l}\text { Normal } \\
\text { Log Normal }\end{array}$ & $\begin{array}{l}2.40 \\
4.76\end{array}$ & $\begin{array}{l}0.75 \\
3.22\end{array}$ \\
\hline $\begin{array}{l}\text { North Process } \\
\text { Pond }\end{array}$ & ACS & $\begin{array}{l}\text { Arsenic } \\
\text { Thallium } \\
\text { Total uranium }\end{array}$ & $\begin{array}{l}\text { Log Normal } \\
\text { Log Normal } \\
\text { Log Normal }\end{array}$ & $\begin{array}{r}1.87 \\
0.26 \\
19.93 \\
\end{array}$ & $\begin{array}{l}1.38 \\
1.43 \\
3.48\end{array}$ \\
\hline Process Trenches & $\mathrm{BCS}$ & $\begin{array}{l}\text { Arsenic } \\
\text { Benzo(a)pyrene } \\
\text { Chrysene } \\
\text { PCBs } \\
\text { Thallium } \\
\text { Total uranium } \\
\end{array}$ & $\begin{array}{l}\text { Normal } \\
\text { Log Normal } \\
\text { Log Normal } \\
\text { Normal } \\
\text { Log Normal } \\
\text { Log Normal } \\
\end{array}$ & $\begin{array}{r}2.98 \\
0.05 \\
0.05 \\
0.72 \\
0.92 \\
30.46 \\
\end{array}$ & $\begin{array}{l}1.92 \\
0.00 \\
0.00 \\
0.07 \\
1.31 \\
2.71 \\
\end{array}$ \\
\hline Burial Ground & $\begin{array}{l}\text { Over- } \\
\text { burden }\end{array}$ & $\begin{array}{l}\text { Arsenic } \\
\text { Thallium }\end{array}$ & $\begin{array}{l}\text { Normal } \\
\text { Normal }\end{array}$ & $\begin{array}{l}1.47 \\
0.42\end{array}$ & $\begin{array}{l}0.38 \\
0.01\end{array}$ \\
\hline Burial Ground & $\mathrm{BCS}$ & $\begin{array}{l}\text { Arsenic } \\
\text { Thallium } \\
\text { Total uranium } \\
\end{array}$ & $\begin{array}{l}\text { Normal } \\
\text { Normal } \\
\text { Normal } \\
\end{array}$ & $\begin{array}{r}1.17 \\
0.41 \\
11.49 \\
\end{array}$ & $\begin{array}{r}0.15 \\
0.02 \\
13.26 \\
\end{array}$ \\
\hline Ash Pits & $\mathrm{N} / \mathrm{A}$ & $\begin{array}{l}\text { Arsenic } \\
\text { Thallium }\end{array}$ & $\begin{array}{l}\text { Normal } \\
\text { Log Normal }\end{array}$ & $\begin{array}{l}3.63 \\
2.71 \\
\end{array}$ & $\begin{array}{l}1.78 \\
3.39 \\
\end{array}$ \\
\hline \multicolumn{6}{|c|}{$\begin{array}{l}\text { a Chemical constituent units in } \mathrm{mg} / \mathrm{kg} \text {; radionuclide contaminant units in } \mathrm{pCi} / \mathrm{g} \text {. } \\
\text { bean and standard deviations were calculated for most of the contaminants of concern within each } \\
\text { waste subsite for which an adequate number of sample results were available from the } 300-\mathrm{FF}-1 \\
\text { Remedial Investigation to establish a distribution. Additional discussion is provided in the text. }\end{array}$} \\
\hline
\end{tabular}


Definitions and specifications:

1. False-positive error: The false-positive error is defined as the probability that the decision unit will be declared below cleanup levels when it is actually above cleanup levels. A 5\% false-positive rate is consistent with the need to calculate a $95 \%$ UCL of the arithmetic or geometric mean (depending on data distribution) and was selected for the statistical calculations.

2. False-negative error: The false-negative error is defined as the probability that the decision unit will be declared above cleanup levels when it is actually below cleanup levels. A false-negative error rate of $20 \%$ was used in the statistical calculations.

3. The cleanup levels for the radionuclides and other COCs are those listed in the 300-FF-1 ROD (EPA 1996) and in Table C-1.

Sampling error typically results from three components of the sampling and analysis process. The individual components of sampling error are additive in nature and comprise the total sampling and analysis error (precision). One component of total error results from the sampling design, the second from taking the samples, and the third from laboratory analysis. The laboratory error (precision) component of total sample design error is usually specified as in Table C-3 prior to taking the samples and is verified upon completion of the laboratory analysis through QC summary data review or data validation. Allowable sample design and sampling errors goals can be specified prior to a sampling event. However, often these errors are not specified upfront but are determined in the total sampling error calculation at the end of data analysis. These types of errors are minimized through process knowledge and implementation of good field sampling procedures. Sample error types and methods to help mitigate these errors are listed in Table C-6.

Table C-6. Components of Total Sample Error and Measures Taken to Reduce That Error.

\begin{tabular}{|l|l|}
\hline $\begin{array}{c}\text { Type of } \\
\text { Sample } \\
\text { Error }\end{array}$ & \multicolumn{1}{|c|}{ Mitigation Procedures or Steps } \\
\hline Design & $\begin{array}{l}\text { Process knowledge operating and construction history, previous sample } \\
\text { analytical and physical properties data, statistical analysis of previous sample } \\
\text { data, geology and hydrology data, current site conditions, operational status }\end{array}$ \\
\hline Sampling & $\begin{array}{l}\text { Field QC including equipment rinsate, trip blanks, field blanks, field duplicates, } \\
\text { field splits, and blind samples; standard operating procedures per BHI-EE-01, } \\
\text { Environmental Investigation Procedures, BHI-MA-02, ERC Project Procedures, } \\
\text { "Document and Information Services" }\end{array}$ \\
\hline Laboratory & $\begin{array}{l}\text { State accreditation; data verification; BHI-EE-01, Section 2.5, "Data Package } \\
\text { Validation;" standard methods; detection limits; accuracy; precision; } \\
\text { completeness }\end{array}$ \\
\hline
\end{tabular}


For the 300-FF-1 Operable Unit, total sampling error was calculated on an individual subwaste site basis (i.e., the South Process Pond ACS and BCS areas). The horizontal and vertical extent of contamination for each contaminant for each subwaste site was determined and those data sets were used to calculate summary statistics. These statistics included the mean, standard deviation, and variance. It is these summary statistics (standard deviation or variance) that provide the estimate of total sample error. This total sample design error was used in the calculation of the minimum number of samples required per waste subsite per contaminant. As discussed earlier, for several of the subwaste sites, the minimum number of samples specified per the formulae was one. Because this is not an adequate number of samples to establish a reasonable data distribution, the decision makers agreed to take a minimum of six samples per subwaste site.

To determine if enough samples were taken, after verification analyses have been completed, the actual standard deviation will be calculated. If the actual staridard deviation is less than or equal to the design standard deviation, enough samples were taken. Also, the actual standard deviation, 95\% UCL, and action levels will be used to generate power curves for the decision makers to use in determining whether the decision error (levels of false positives and negatives) at the action level is acceptable.

\section{II.3.1.6 Backfill}

Onsite backfill that comes from overburden will have been previously sampled and analyzed as described in Section II.3.1.4. Any perimeter and interior dikes of the North and South Process Ponds and the Process Trenches to be used as backfill will also have been verified as being below cleanup levels as described in Section II.3.1.5.

The sampling strategy for the stockpile area south of the Ash Pits and Filter Backwash Pond for use as backfill is the same as that described for verification sampling. After completion of a surface radiation survey, six soil samples of the soil stockpile area will be randomly sampled by ERC personnel with the help of RAS personnel and equipment to excavate and obtain samples from the interior of the pile at depths up to 3 to $4.5 \mathrm{~m}$ (10 to $15 \mathrm{ft}$ ). These samples will be analyzed for all COCs and will not be composited. If these analyses confirm that the soil stockpile is below cleanup levels, it can then be used as backfill within the 300-FF-1 waste sites during the restoration process. Any stockpile areas above cleanup levels will be excavated and sent to ERDF for disposal.

The sampling strategy for any imported backfill material is based on the process knowledge of the source borrow pits. If these borrow pits are located in uncontaminated areas, there is no need for sampling and analysis of this material.

\section{II.3.1.7 Debris and Structures}

Debris and structures include items such as metallic objects, old bird screens, concrete lids, wood and timber pieces, abandoned telephone poles, fencing and fenceposts, concrete structures, the small blockhouse on the east side of the Process Trenches, and process piping. Debris that may 
have been incidental to the operation of the waste sites (e.g., fences, telephone poles, bird screens) and the exposed ends of process piping will be surveyed for radiation by ERC personnel using standard equipment. Debris found within the landfills or the 618-4 Burial Ground will be evaluated by ERC personnel during excavation and passing of the debris through a grizzly screen to identify wastes that may not be acceptable to ERDF. The need for, and type of, any additional sampling and characterization to be performed for debris and structures will be evaluated by the ERC on a case-by-case basis. For instance, additional sampling would be needed to identify containers of liquids, powders or sludges, or other unknown materials to confirm that they will meet the ERDF waste acceptance criteria (BHI 1996b). Such sampling, if necessary, is likely to consist of single grab samples to be analyzed, at a minimum, for all COCs.

\section{II.3.2 ANALYTICAL METHOD REQUIREMENTS}

Offsite laboratory analytical parameters and methods are listed in Tables C-3 and C-4 for soils and water, respectively. Laboratory-specific standard operating procedures for the analytical methods will be in place before any sampling. The offsite laboratory turnaround times will vary depending on the QA/QC data package needed to support the sample results. For example, profiling of suspect waste material from the landfills or the 618-4 Burial Ground may require shorter turnaround times than the final verification samples.

ERC personnel will conduct in-process screening for uranium using a portable survey instrument with a sodium iodide detector connected to a backpack GPS. Although testing of a possible instrument to be used for conducting the in-process screening is underway, the analytical method requirements for the survey system are described below.

The MDA for the in-process screening system was discussed in Section I.4.1. The isotopes of concern for designing the system are uranium-234, uranium-235, uranium-238, thorium-231, thorium-234, and protactinium-234. The activity of the uranium-234, uranium-238, thorium-234, and protactinium-234 is assumed to be in equilibrium in the soil. The activity of the uranium- 235 and thorium-231 at realistic uranium-235 enrichments $(<1.5 \%)$ will each be less than 0.1 times the activity of the uranium-238.

While all of the above isotopes emit gammas of various energies, the most abundant are lower than $100 \mathrm{KeV}$ and the largest is slightly more than $200 \mathrm{KeV}$. This will limit the penetrating power of the gamma radiation to about $2.5 \mathrm{~cm}$ ( 1 in.), which will be verified in field tests of the system.

The beta radiation energies are higher than the gamma: $0.747 \mathrm{MeV}$ to $2.3 \mathrm{MeV}$ for protactinium-234 and around $0.2 \mathrm{MeV}$ for the remaining isotopes. However, the charge and size of the beta particle reduce its penetrating power, which is assumed to also be about $2.5 \mathrm{~cm}$ ( $1 \mathrm{in}$.). This will also be verified in field tests of the system. 
Although all three uranium isotopes decay by emission of an alpha particle, which is generally easy to detect, the mixture of uranium in the waste site soils means that the alpha particles will be shielded by the soil. For these reasons as well as previous field experience, uranium is more easily detected with beta-gamma instrumentation than with alpha instrumentation.

The field screening for metals will be conducted using a portable XRF spectrometer, and the field screening for VOCs will be conducted using an OVM and an OVA.

\section{II.3.3 QUALITY CONTROL REQUIREMENTS}

The following $\mathrm{QC}$ requirements are detailed in the standard operating procedures that are referenced in Table C-7:

- $\quad$ Specific QC procedures

- $\quad$ Level of effort (frequency of runs)

- QC limits

- $\quad$ Corrective action requirements.

Table C-7. Analytical Standard Operating Procedures.

\begin{tabular}{|l|l|}
\hline \multicolumn{2}{|c|}{ In Situ Field Measurements } \\
\hline BHI-EE-05 & Field Screening Procedures (as applicable) \\
\hline BHI-00852 & $\begin{array}{l}\text { Onsite Measurements Quality Assurance Plan } \\
\text { (BHI 1996c) }\end{array}$ \\
\hline \multicolumn{1}{|c|}{ Offsite Verification Laboratory } \\
\hline Commercial Laboratory (state accredited) & $\begin{array}{l}\text { Corporate Analytical Procedures and Quality } \\
\text { Assurance Plan }\end{array}$ \\
\hline
\end{tabular}

\section{II.3.4 INSTRUMENT/EQUIPMENT TESTING, INSPECTION, AND MAINTENANCE REQUIREMENTS}

Inspection and maintenance requirements will be per manufacturers' instrument manuals and the applicable quality assurance plan.

\section{II.3.5 INSPECTION/ACCEPTANCE REQUIREMENTS FOR SUPPLIES AND CONSUMABLES}

Procurement activities for this project will meet the requirements of BHI-PR-01, ERC Procurement Procedures. 
ERC personnel assigned the receiving inspection function will review received items for conformation to specifications set in the requisition. If the item does not meet specifications, the item will be dispositioned through the nonconformance system.

\section{II.3.6 DATA ACQUISITION REQUIREMENTS (NONDIRECT MEASUREMENTS)}

Nondirect data are obtained from three database/information management systems that are used to manage past-practice information for the Hanford Site. The type of data in each of the three databases includes the following: (1) summary chemical and waste type information in the WIDS, which includes the official name and source references, including documents, photographs, and drawings for each waste site; (2) basemap data (geographic location information based on surveys and global position measurement data) for each waste site are obtained from the Hanford Geographical Information System (HGIS); and (3) chemical and radiological data for each waste site are obtained from the Hanford Environmental Information System (HEIS), including historical sample data, as well as recent site characterization sample data. The past-practice data for this project have been verified and validated according to procedures for the WIDS and HGIS databases and for the project characterization sample data in the HEIS database, that is traceable to laboratory methods and, where available, detection limit information. Documented procedures were used to collect the project characterization samples.

\section{II.3.7 DATA MANAGEMENT}

The sample and data management process for field and sample analytical data is shown in Figure C-3. This process tracks the current project sample data flow through collection, analysis, verification/validation, and storage in the same data management databases discussed above. Both the past-practice and current project data are managed under documented configuration control procedures.

The sample and data management process will be used to manage the field radiological measurements, on location metals and organics measurements, and the standard fixed laboratory analyses to develop data tables and maps to guide the remediation. The data process control system will also be used to obtain and communicate data results to support closeout decisions. All verification data will be stored in the HEIS. 
DOE/RL-96-70

Rev. 0

Figure C-3. Sample and Data Management Process Flow.

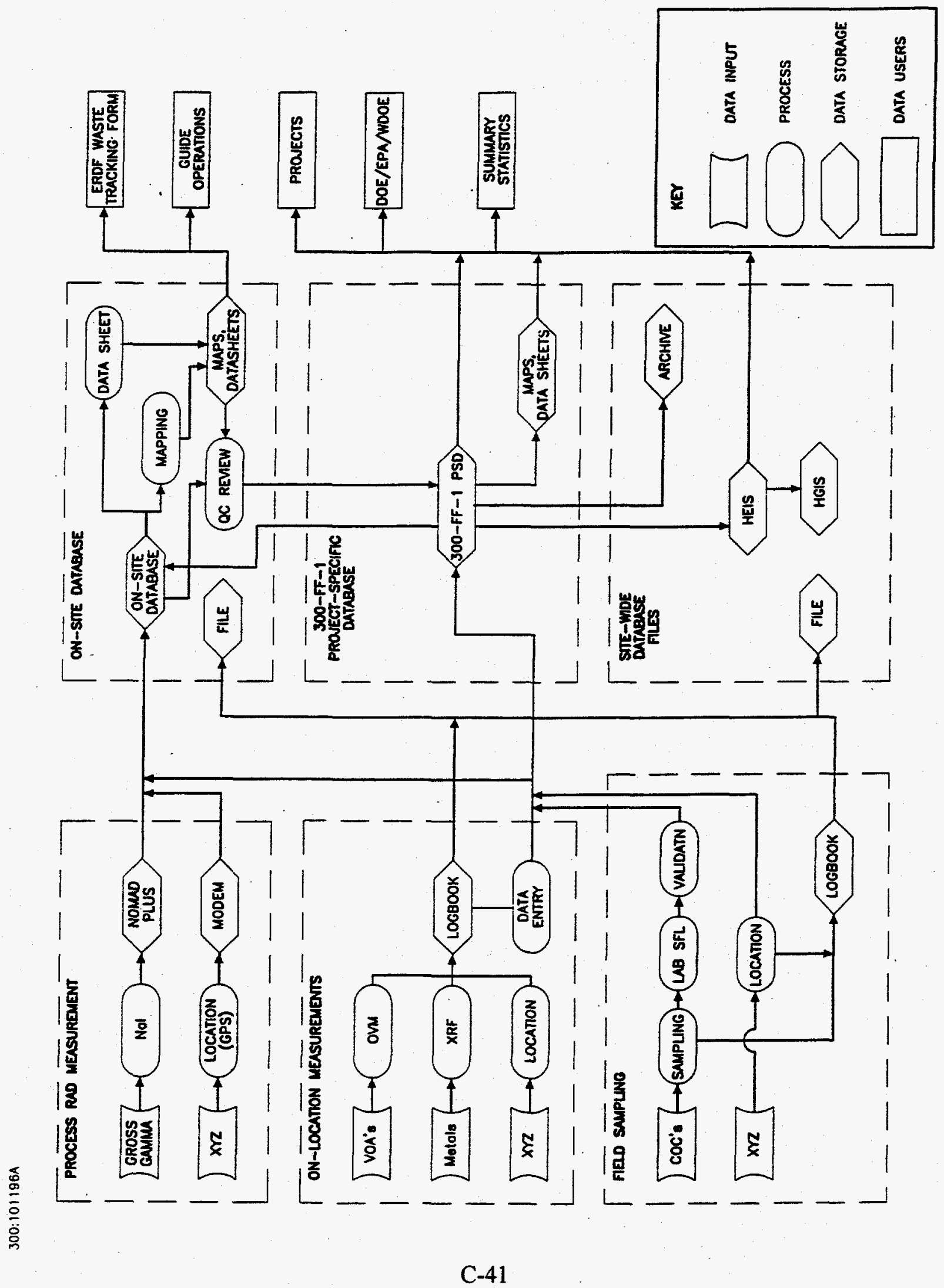


DOE/RL-96-70

Rev. 0

\section{II.4.0 ASSESSMENT/OVERSIGHT}

\section{II.4.1 ASSESSMENTS AND RESPONSE ACTIONS}

ERC QA staff will conduct random surveillance and audits to verify compliance with the requirements outlined in this QAPJP, the ERC Quality Management Plan, and ERC procedures and regulatory requirements. Collectively, the data collection, processing, verification/ validation, management, self-assessment, and QA programs will address quality-affecting activities that include, but are not limited to, the measurement system accuracy and field activities.

Random surveillance and audits will be structured to meet the following system and performance audit classification. System audits consist of the evaluation of the components of the measurement systems to determine their proper selection and use. Performance audits ensure the accuracy of the total system and its individual parts.

\section{II.4.2 REPORTS TO MANAGEMENT}

Corrective action required as a result of surveillance reports, nonconformance reports, or audit activities will be documented and dispositioned, as required by BHI-MA-02, Section 2.1, "Corrective Action." Other measurement systems, procedures, or plan corrections that may be required, as a result of routine review processes, will be resolved as required by governing procedures or will be referred to the ERC project engineer for resolution.

Project activities will be regularly assessed by random audits, surveillance, and assessments. All findings from audits, surveillance, and assessments will be transmitted to the ERC project manager and ERC QA department for program-related tracking and trending. Otherwise, the routine evaluation of data quality described throughout this QAPjP will be documented and filed along with the data in the project file.

\section{II.5.0 DATA VALIDATION AND USABILITY}

\section{II.5.1 DATA REVIEW, VALIDATION, AND VERIFICATION REQUIREMENTS}

All offsite laboratory data will be validated at Level A (verification of required deliverables, requested versus reported analyses, and evaluation and qualification of results based on holding times). A minimum of 5\% of the samples in each SDG of the offsite laboratory data will be validated at Level C (Level A plus qualification based on method blank results, matrix spike, 
surrogate recoveries, and duplicates). A State of Washington accredited laboratory for water analysis will be used, otherwise $10 \%$ of the samples will be validated. All coordination of validation services, execution of data validation activities, and handling/storage of deliverables will be in accordance with BHI-EE-01, Section 2.5, "Data Package Validation Process."

The in-process screening, XRF, and OVM/OVA data will not undergo a formal validation. The data will be reviewed by ERC analytical personnel and project team members to verify that the data meet the required limits in Table C-2, as described in Section II.2.3.

\section{II.5.2 VALIDATION AND VERIFICATION METHODS}

Data validation will be done in accordance with WHC-SD-EN-SPP-001, Data Validation Procedure for Radiochemistry Analyses (WHC 1993a), and WHC-SD-EN-SPP-002, Data Validation Procedures for Chemical Analyses (WHC 1993b). Validation levels and the percentage of data to be validated are described in Section II.5.1.

\section{II.5.3 RECONCILIATION WITH USER REQUIREMENTS}

Following validation, the data will be assessed by the project team. Assessment will include incorporation of the data validation findings into the database by entry of data qualifiers by the appropriate personnel and review of all data qualifiers, including laboratory-assigned data qualifiers.

The data validation reports will also be reviewed by ERC personnel to assess whether the data are acceptable. If no data are rejected in the validation reports, the data will be considered to be acceptable. If any data are rejected in the validation reports or the quantitative DQOs are not met, the project manager, or designee, shall conduct an assessment per QAPjP Section II.4.0 to determine a root cause. Based on the outcome of the assessment, the project manager shall determine the useability of the data and/or implement the appropriate corrective action. The quantitative DQOs are defined below.

\section{II.5.3.1 Precision}

If calculated from duplicate measurements:

$$
R P D=\left\lfloor\frac{\left(C_{1}-C_{2}\right)}{\left(C_{1}+C_{2}\right) / 2}\right\rfloor \times 100
$$




\section{DOE/RL-96-70}

Rev. 0

where:

$\mathrm{RPD}=$ relative percent difference

$\mathrm{C}_{1}=$ sample value

$\mathrm{C}_{2}=$ duplicate value.

\section{II.5.3.2 Accuracy}

For measurements where matrix spikes are used:

$$
\% R=\left[\frac{s-U}{C_{s a}}\right] X 100
$$

where:

$\% \mathrm{R}=$ percent recovery

$\mathrm{S}=$ measured concentration in spiked aliquot

$\mathrm{U}=$ measured concentration in unspiked aliquot

$\mathrm{C}_{\mathrm{sa}}=$ actual concentration of spike added.

For situations where a laboratory control sample is used instead of or in addition to matrix spikes:

$$
\% R=\left[\frac{C_{m}}{C_{l e s}}\right] X 100
$$

where:

$\% \mathrm{R}=$ percent recovery

$\mathrm{C}_{\mathrm{m}}=$ measured concentration of laboratory control sample

$\mathrm{C}_{\mathrm{lcs}}=$ actual concentration of laboratory control sample.

\section{II.5.3.3 Completeness}

Defined as follows for all measurements:

$$
\% C=\left[\frac{V}{T}\right] \times 100
$$


where:

$\% \mathrm{C}=$ percent completeness

$\mathrm{V}=$ number of measurements judged valid

$\mathrm{T}=$ total number of measurements.

\section{II.5.3.4 Detection Limit}

Defined as follows for nonradionuclide measurements:

$$
M D L=t_{(n-1,1-\alpha=0.99)} \times S
$$

where:

MDL $\quad=$ method detection limit

$\mathrm{S} \quad=$ standard deviation of the replicate analyses

$t_{(\mathrm{n}-1,1, \alpha=0.99)}=$ students' $\mathrm{t}$-value appropriate to a $99 \% \mathrm{UCL}$ and a standard deviation estimate with n-1 degree of freedom.

For radionuclides, the method detection limit will be per Currie calculations (Currie 1968). 
DOE/RL-96-70

Rev. 0

C-46 
DOE/RL-96-70

Rev. 0

PART III

FIELD SAMPLING PLAN

\section{III.1.0 SAMPLING OBJECTIVES}

The objectives for each sampling group are described in the following sections.

\section{III.1.1 IN-PROCESS SCREENING}

The sampling objectives for the in-process screening radiological survey system are to provide at least a $90 \%$ UCL that the residual radioactivity that equals or exceeds the uranium cleanup level of $350 \mathrm{pCi} / \mathrm{g}$ will be detected when present. This can be achieved by balancing scan speed, background readings, and instrument efficiency.

The screening will be conducted over the surfaces of waste sites and on soils excavated from test trenches and test pits. After confirmation that the radioactive contaminants are below cleanup levels, field screening surveys for metals (by XRF) and VOCs (by OVM and OVA) will be conducted at final excavation grade before collection of final verification samples to ensure that these COCs are below cleanup levels.

\section{III.1.2 DISPOSAL}

Waste profiles for each waste site will be prepared based on the RI data and process knowledge in accordance with the ERDF waste acceptance criteria (BHI 1996b). The in-process radiation screening will be used at all waste sites to confirm that the wastes are within the waste profile ranges. At the landfills and the 618-4 Burial Ground, field screening of soils for RCRA metals and organics will also be used to confirm that the wastes are within the waste profile ranges. Metals will be analyzed using XRF, and organics will be analyzed using an OVM and an OVA. A surface grab soil sample will be collected and analyzed by XRF at a minimum of one sample per $115 \mathrm{~m}^{3}\left(150 \mathrm{yd}^{3}\right)$ excavated. XRF sample collection must be done before excavation and the results made available to the RAS so that double handling of excavated soils is avoided. The OVM will be used to continuousiy monitor the surface soils being excavated. If the OVM detects concentrations of organics greater than $5 \mathrm{ppm}$ above background, a surface grab soil sample will be collected and analyzed by OVA to help identify the organic compound.

Additional sampling may be necessary to characterize materials such as containers containing liquids, powders, or sludges; greater than Class $\mathrm{C}$ radioactive material; friable asbestos; or other unacceptable materials. The need for, and type of, any additional sampling and characterization to be performed for disposal will be evaluated by the ERC on a case-by-case basis. 
Rev. 0

\section{III.1.3 DECONTAMINATION}

The sampling objective for the decontamination wash water is to provide data to support decisions regarding the most appropriate disposal method when there are no areas above cleanup levels left to be excavated onsite.

\section{III.1.4 OVERBURDEN}

Overburden is the soil previously placed on top of a waste site. The objective for sampling and analysis of overburden is to verify that these uppermost soils do not contain COCs above cleanup levels so that the overburden can be removed and stockpiled onsite for reuse in regrading the waste site.

\section{III.1.5 VERIFICATION}

The objective of the verification sampling is to confirm that soils to be left in place at each waste site are below cleanup levels. These samples will be analyzed for all COCs at an offsite analytical laboratory.

\section{III.1.6 BACKFILL}

One goal of the 300-FF-1 remediation is to regrade the waste site slopes without using any imported backfill. Backfill will also come from the soil stockpile area south of the Ash Pits and Filter Backwash Pond. The objective of the backfill sampling is to confirm that soils to be used in regrading each waste site are below cleanup levels. These samples will be analyzed for all COCs at an offsite analytical laboratory.

If imported backfill is obtained from borrow pits located in uncontaminated areas, there is no need for sampling and analysis of this material.

\section{III.1.7 DEBRIS AND STRUCTURES}

Debris and structures include items such as metallic objects, old bird screens, concrete lids, wood and timber pieces, abandoned telephone poles, fencing and fenceposts, concrete structures, the small blockhouse on the east side of the Process Trenches, and process piping.

The objectives for the surveying or sampling of these items are to (1) determine whether such items may be reused or recycled and can be released and (2) determine if they can be buried within the appropriate waste site or must be sent to ERDF for disposal. 
Debris that may have been incidental to the operation of the waste sites (e.g., fences, telephone poles, bird screens) and the exposed ends of process piping will be surveyed for radiation by ERC personnel using standard equipment. Debris found within the landfills or the 618-4 Burial Ground will be evaluated by ERC personnel during excavation and passing of the debris through a grizzly screen to identify wastes that may not be acceptable to ERDF. The need for, and type of, any additional sampling and characterization to be performed for debris and structures will be evaluated by the ERC on a case-by-case basis. For instance, additional sampling would be needed to identify containers of liquids, powders, or sludges, or other unknown materials to confirm that they will meet the ERDF waste acceptance criteria (BHI 1996b). Such sampling, if necessary, is likely to consist of single grab samples to be analyzed, at a minimum, for all COCs.

\section{III.2.0 SAMPLING LOCATIONS AND FREQUENCIES}

General sampling locations for each sampling group, as well as the sampling frequencies, are summarized in Table C-8. Within the North and South Process Pond perimeter dikes and interior berms where the existing data are inconclusive as to whether the COCs are above or below cleanup levels, test trenches will be excavated to the depth of the bottom of the dike/berm at the locations shown in Figures $\mathrm{C}-4$ and C-5. Concurrent with the excavation, ERC personnel will screen the excavated material and the trench sidewalls. The in-process screening system will be used to survey excavated soils at approximately $0.3-\mathrm{m}-(1-\mathrm{ft})$ depth intervals at a minimum of three locations along each trench to help determine and define soil areas that are above cleanup levels. If necessary to help define the soil excavation boundaries, additional trenches may be located between the initial trenches.

Test pit excavation and in-process screening sampling described above will also be used in the Process Trenches Spoils Area (undetermined contamination portion), the North Process Pond Scraping Disposal Area, and the Ash Pits area (Figures C-4 and C-5). Four test pits in the Process Trenches Spoils Area (undetermined contamination portion) will be excavated to the base of the spoils pile. If the soils from these test pits are below the uranium cleanup level, two additional test pits will be excavated to the base of the spoils pile as shown in Figure C-4, and a verification soil sample will be collected from the soil directly beneath the spoils in each of the four test pits. After the RAS removes the concrete apron at the southern end of each trench, one verification soil sample will be collected from the soils beneath the apron in each trench. If field screening indicates that the soils are below cleanup standards, the standard $\mathrm{COC}$ list will be analyzed. If field screening indicates that the soils are above cleanup standards (would need to be shipped to ERDF), the samples will be analyzed for the COCs, plus the RCRA TCLP metals (chromium, arsenic, lead, barium, cadmium, mercury, selenium, and silver), plus the following volatiles: 2-butanone(methyl ethyl ketone), carbon tetrachloride, toluene, xylenes (total), and chlorobenzene. This second list of analytes is required in order to obtain a contained-in determination from Ecology in order to ship these soils to ERDF. 
Rev. 0

Table C-8. Sample Locations, Frequencies, and Sampling Methods. (sheet 1 of 2)

\begin{tabular}{|c|c|c|c|}
\hline \multirow{2}{*}{$\begin{array}{l}\text { Sampling } \\
\text { Objective }\end{array}$} & \multirow{2}{*}{$\begin{array}{l}\text { Sampling } \\
\text { Location }\end{array}$} & \multicolumn{2}{|c|}{ Physical Samples } \\
\hline & & Sample Frequency & Sampling Methods \\
\hline $\begin{array}{l}\text { In-process } \\
\text { screening }\end{array}$ & $\begin{array}{l}\text { All waste site } \\
\text { surfaces } \\
\text { Under } \\
\text { decontamination } \\
\text { tanks during } \\
\text { demobilization } \\
\text { Trench and/or } \\
\text { test pit samples }\end{array}$ & $\begin{array}{l}\text { Minimum } 10 \% \text { of the } \\
\text { surface } \\
\text { Minimum } 10 \% \text { of the } \\
\text { surface } \\
\text { Minimum } 0.3-\mathrm{m}-(1-\mathrm{ft}) \\
\text { depth intervals }\end{array}$ & $\begin{array}{l}\text { Radiation surveying } \\
\text { Radiation surveying } \\
\text { Radiation surveying }\end{array}$ \\
\hline Disposal & $\begin{array}{l}\text { Landfills } 1 \mathrm{a}, 1 \mathrm{~b}, \\
1 \mathrm{~d} \text {, and the } 618-4 \\
\text { Burial Ground }\end{array}$ & $\begin{array}{l}1 \text { per } 115 \mathrm{~m}^{3}\left(150 \mathrm{yd}^{3}\right) \\
\text { minimum } \\
\begin{array}{l}\text { Continuous monitoring } \\
\text { during excavation }\end{array} \\
1 \text { per suspect waste } \\
\text { material }\end{array}$ & $\begin{array}{l}\text { Surface soil grab sample } \\
\text { Organic vapor monitor/ } \\
\text { organic vapor analyzer } \\
\text { readings } \\
\text { Surface soil grab sample } \\
\text { or grab from container }\end{array}$ \\
\hline $\begin{array}{l}\text { Decontamina- } \\
\text { tion }\end{array}$ & $\begin{array}{l}\text { Decontamination } \\
\text { water holding } \\
\text { tank }\end{array}$ & $\begin{array}{l}1 \text { per each } 3 / 4 \text { full tank } \\
\text { (after no above cleanup } \\
\text { areas left onsite) }\end{array}$ & $\begin{array}{l}\text { Grab of supernatant } \\
\text { liquid }\end{array}$ \\
\hline Overburden & $\begin{array}{l}\text { Landfills la, } 1 \mathrm{~b}, \\
1 \mathrm{~d} \text {, and the } 618-4 \\
\text { Burial Ground }\end{array}$ & 6 per waste site & Surface soil grab sample \\
\hline
\end{tabular}


DOE/RL-96-70

Rev. 0

Table C-8. Sample Locations, Frequencies, and Sampling Methods. (sheet 2 of 2)

\begin{tabular}{|c|c|c|c|}
\hline \multirow{2}{*}{$\begin{array}{l}\text { Sampling } \\
\text { Objective }\end{array}$} & \multirow{2}{*}{$\begin{array}{l}\text { Sampling } \\
\text { Location }\end{array}$} & \multicolumn{2}{|c|}{ Physical Samples } \\
\hline & & Sample Frequency & Sampling Methods \\
\hline Verification & $\begin{array}{l}\text { Each waste site } \\
\text { or waste site } \\
\text { subarea }\end{array}$ & $\begin{array}{l}6 \text { per waste site or waste } \\
\text { site subarea (except for } \\
\text { South Process Pond) } \\
\text { Under decontamination } \\
\text { tanks if required per in- } \\
\text { process screening } \\
13 \text { in South Process Pond } \\
\text { (above cleanup) and } 19 \text { in } \\
\text { South Process Pond } \\
\text { (below cleanup) } \\
300-10 \text { Site } \\
2 \text { under Process Trenches } \\
\text { concrete aprons }\end{array}$ & $\begin{array}{l}\text { Surface soil grab sample } \\
\text { Surface soil grab sample } \\
\text { Surface soil grab sample } \\
\text { Radiation surveying } \\
\text { Metal detector surveying } \\
\text { Surface soil grab sample }\end{array}$ \\
\hline Backfill & $\begin{array}{l}\text { Soil stockpile } \\
\text { area }\end{array}$ & $\begin{array}{l}\text { Minimum } 10 \% \text { of the } \\
\text { surface } \\
6 \text { per stockpile area }\end{array}$ & $\begin{array}{l}\text { Surface radiation survey } \\
\text { Surface soil grab sample } \\
\text { and grab from backhoe }\end{array}$ \\
\hline $\begin{array}{l}\text { Debris and } \\
\text { structures }\end{array}$ & $\begin{array}{l}\text { Where found } \\
\text { within the } \\
300-F F-1 \\
\text { Operable Unit }\end{array}$ & $\begin{array}{l}\text { Radiation survey } \\
1 \text { per suspect waste } \\
\text { material }\end{array}$ & $\begin{array}{l}\text { Radiation surveying } \\
\text { Grab from container }\end{array}$ \\
\hline
\end{tabular}


Figure C-4. Sample Locations in Northern Waste Sites.

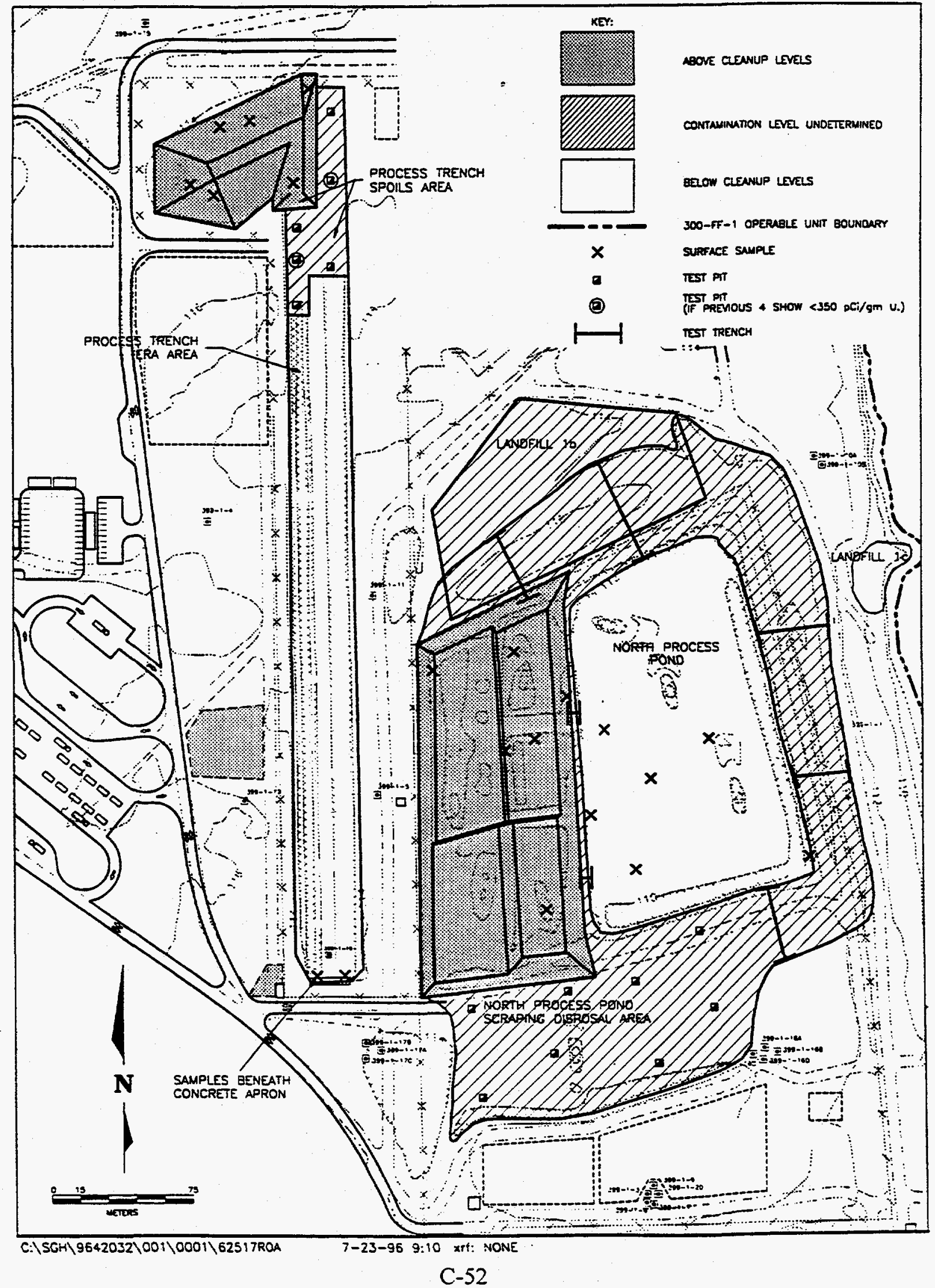




\section{DOERL- $96-70$
Rev. 0}

Figure C-5. Sample Locations in

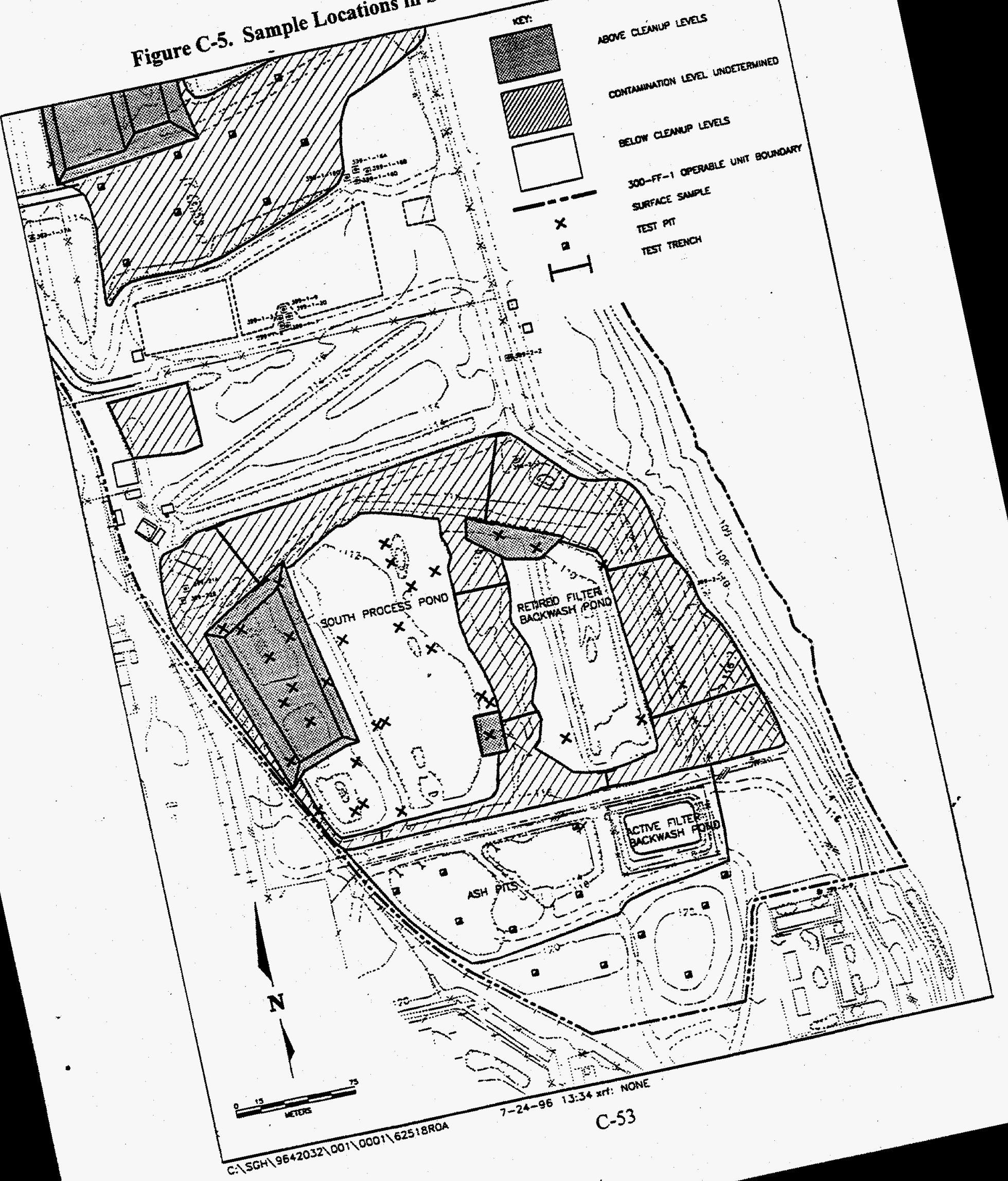


Rev. 0

Eight test pits will be excavated in the North Process Pond Scraping Disposal Area to an approximately $5-\mathrm{m}(15-\mathrm{ft})$ depth. If the soils from these test pits are below the uranium cleanup level, six random soil samples from these test pits will be submitted as verification samples. Six test pits will be excavated in the Ash Pits to an approximately 5-m (15-ft) depth. If the soils beneath the upper ash material are below the uranium cleanup level, one soil sample from each test pit will be submitted as a verification sample.

The stratified simple random sampling method described in EPA.(1989) was used to identify the locations of surface verification samples in the Process Trenches Spoils Pile (above cleanup lobe), North Process Pond, and South Process Pond using the sample numbers discussed in Section II.3.1.5 (Figures C-4, C-5, and Attachment 1). The locations selected in the "above cleanup levels" areas of these waste sites may need to be recalculated if the area of soil removal is significantly greater than that shown in Figures C-4 and C-5. Samples collected in the Retired Filter Backwash Pond (east lobe of the South Process Pond) "below cleanup levels" area shall be collected from soils beneath the filter backwash (alum) material, which is considered to be less

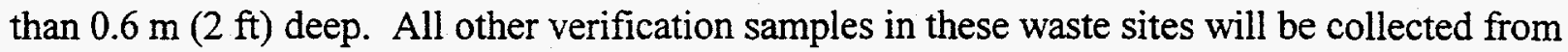
surface soils at the time of sampling.

Separate verification sampling is not needed to confirm cleanup of the small surface radiation area just west of the 618-4 Burial Ground. Cleanup of the 300-10 surface radiation area west of the Process Trenches will be confirmed by an in-process surface radiation survey followed by a metal detector survey.

\section{III.3.0 SAMPLING METHODS}

Sampling methods are shown in Table C-8. Sampling will follow ERC standard operating procedures per BHI-EE-01, Environmental Investigations Procedures.

\section{III.4.0 FIELD QUALITY CONTROL SAMPLING}

Field QC sampling requirements are summarized in Table C-9. 
DOE/RL-96-70

Rev. 0

Table C-9. Field Quality Control Sampling Requirements Summary.

\begin{tabular}{|l|l|l|}
\hline Quality Control Sample Type & \multicolumn{1}{|c|}{ Application } & \multicolumn{1}{|c|}{ Frequency Reference } \\
\hline Trip blanks & $\begin{array}{l}\text { Volatile organic sampling } \\
\text { only. }\end{array}$ & I sample per SDG. \\
\hline Equipment rinsates (blanks) & All sampling. & $\begin{array}{l}\text { 1 sample per waste site or } \\
\text { waste site subarea. }\end{array}$ \\
\hline Field source water blanks & $\begin{array}{l}\text { Not applicable. Field water } \\
\text { or steam cleaning equipment } \\
\text { only. }\end{array}$ & \multicolumn{1}{|c|}{} \\
\hline Field duplicates & All sampling. & $\begin{array}{l}5 \% \text { of all samples (1 in } \\
20 \text { samples) or 1 per SDG } \\
\text { and a minimum of 1 sample } \\
\text { per sampling group. }\end{array}$ \\
\hline Field splits & All sampling. & $\begin{array}{l}5 \% \text { of all samples (1 in } \\
20 \text { samples) or 1 per SDG } \\
\text { and a minimum of 1 sample } \\
\text { per sampling group. }\end{array}$ \\
\hline Co-located samples & $\begin{array}{l}\text { Not applicable. Volatile } \\
\text { organic sampling only. }\end{array}$ & $\begin{array}{l}1 \text { sample per waste site or } \\
\text { waste site subarea. }\end{array}$ \\
\hline Field blanks & All sampling. & $\begin{array}{l}\text { As determined by field } \\
\text { management. }\end{array}$ \\
\hline Blind samples & To ensure data integrity. \\
\hline SDG = sample delivery group & & \\
\hline
\end{tabular}

\section{III.5.0 SAMPLE MANAGEMENT}

\section{III.5.1 SAMPLE CUSTODY}

\section{III.5.1.1 Field Custody}

All samples obtained during the course of this project will be controlled from the point of origin to the analytical laboratory, as required by BHI-EE-01, Environmental Investigations Procedure (EIP) 3.0, "Chain of Custody." 
DOE/RL-96-70

Rev. 0

\section{III.5.1.2 Laboratory Custody Procedures}

Sample custody during laboratory analysis will be addressed in the applicable laboratory standard operating procedures. Laboratory custody procedures will ensure the maintenance of sample integrity and identification throughout the analytical process.

\section{III.5.2 SAMPLE PRESERVATION, CONTAINERS, AND HOLDING TIMES}

Sample preservation, container size and type, and holding times for offsite laboratory analyses are summarized in Table $\mathrm{C}-10$ and will be noted on the sample authorization form in accordance with EIP 2.0, "Sample Event Coordination."

\section{III.5.3 SAMPLE SHIPPING}

Sample packaging and shipping will be performed in accordance with EIP 3.1, "Sample Packaging and Shipping."

\section{III.5.4 FIELD DOCUMENTATION}

All relevant documents, records, reports, logs, field notebooks, pictures, subcontract reports, and analytical reports will be submitted, secured, and stored in accordance with BHI-MA-02, ERC Project Procedures, Procedure 1.7, "ERC Records Management." 
DOE/RL-96-70

Rev. 0

Table C-10. Sample Containers, Types, Preservation, and Holding Times.

\begin{tabular}{|c|c|c|c|c|}
\hline Constituent & Matrix & $\begin{array}{c}\text { Container Size } \\
\text { and Type }\end{array}$ & $\begin{array}{l}\text { Preservation and } \\
\text { Handling }\end{array}$ & $\begin{array}{c}\text { Maximum } \\
\text { Holding Time } \\
\text { from Collection } \\
\text { Date }\end{array}$ \\
\hline \multirow{2}{*}{ Radionuclides } & Soil & $\begin{array}{c}250-\mathrm{mL}(8-\mathrm{oz}) \\
\text { glass or } \\
\text { polyethylene }\end{array}$ & $4 \pm 2^{\circ} \mathrm{C}$ & 6 months \\
\hline & Water & $\begin{array}{l}\text { 3.8-L }(1 \text {-gal }) \\
\text { cube container }\end{array}$ & $\mathrm{HNO}_{3} \mathrm{pH}<2$ & 6 months \\
\hline \multirow{2}{*}{ Metals } & Soil & $\begin{array}{l}250-\mathrm{mL}(8-\mathrm{oz}) \\
\text { glass or } \\
\text { polyethylene }\end{array}$ & $4 \pm 2^{\circ} \mathrm{C}$ & 6 months \\
\hline & Water & $\begin{array}{c}\text { 250-mL (8-oz) } \\
\text { HDPE }\end{array}$ & $\mathrm{HNO}_{3} \mathrm{pH}<2$ & 6 months \\
\hline \multirow[t]{2}{*}{ Organics } & Soil & $\begin{array}{l}250-\mathrm{mL}(8-\mathrm{oz}) \\
\text { glass or } \\
\text { polyethylene }\end{array}$ & $4 \pm 2^{\circ} \mathrm{C}$ & $\begin{array}{l}7 \text { days to } \\
\text { extraction, } \\
33 \text { days to } \\
\text { analysis }\end{array}$ \\
\hline & Water & $\begin{array}{l}\text { Two } 40-\mathrm{mL} \\
\text { (1.3-oz) glass } \\
\text { VOC vials }\end{array}$ & 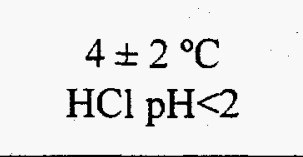 & 14 days \\
\hline $\begin{array}{l}\text { Polychlorinated } \\
\text { biphenyls }\end{array}$ & Water & $\begin{array}{l}\text { 1-L (34-oz) } \\
\text { amber glass, } \\
\text { teflon-lined cap }\end{array}$ & $4 \pm 2^{\circ} \mathrm{C}$ & $\begin{array}{l}7 \text { days to } \\
\text { extraction, } \\
33 \text { days to } \\
\text { analysis }\end{array}$ \\
\hline
\end{tabular}


DOE/RL-96-70

Rev. 0

C-58 
DOE/RL-96-70

Rev. 0

\section{REFERENCES}

BHI-EE-01, Environmental Investigations Procedures, Bechtel Hanford, Inc., Richland, Washington.

BHI-EE-05, Field Screening Procedures, Bechtel Hanford, Inc., Richland, Washington.

BHI-HR-02, ERC Training Procedures, Bechtel Hanford, Inc., Richland, Washington.

BHI-MA-02, ERC Project Procedures, Bechtel Hanford, Inc., Richland, Washington.

BHI-PR-01, ERC Procurement Procedures, Rev. 2, Bechtel Hanford, Inc., Richland, Washington.

BHI-QA-02, ERC Quality Program, Bechtel Hanford, Inc., Richland, Washington.

BHI, 1996a, 300-FF-1 Remedial Action Sampling and Analysis Plan DQO Process Summary Report, BHI-00942, Rev. 0, Bechtel Hanford, Inc., Richland, Washington.

BHI, 1996b, Environmental Restoration Disposal Facility Waste Acceptance Criteria, BHI-00139, Rev. 2, Bechtel Hanford, Inc., Richland, Washington.

BHI, 1996c, Onsite Measurements Quality Assurance Plan, BHI-00852, Rev. 0, Bechtel Hanford, Inc., Richland, Washington.

Currie, L. A., 1968, "Limits for Qualitative Detection and Quantitative Determination," Analytical Chemistry, Vol. 40, No. 3, March 1968, pp. 586-593.

DOE-RL, 1993a, Phase I Remedial Investigation Report for the 300-FF-5 Operable Unit, DOE/RL-93-21, Rev. 0, U.S. Department of Energy, Richland Operations Office, Richland, Washington.

DOE-RL, 1993b, Phase I Remedial Investigation Report for the 300-FF-1 Operable Unit, DOE/RL-92-43, Rev. 0, U.S. Department of Energy, Richland Operations Office, Richland, Washington.

DOE-RL, 1995a, 300 Area Process Trenches Modified Closure/Postclosure Plan, DOE/RL-93-73, Rev. 1, U.S. Department of Energy, Richland Operations Office, Richland, Washington.

DOE-RL, 1995b, Phase III Feasibility Study Report for the 300-FF-1 Operable Unit, DOE/RL-94-49, Rev. 0, U.S. Department of Energy, Richland Operations Office, Richland, Washington. 
DOE-RL, 1995c, Proposed Plan for the 300-FF-1 and 300-FF-5 Operable Units, DOE/RL-95-88, Rev. 0, U.S. Department of Energy, Richland Operations Office, Richland, Washington.

HSRCM, 1994, Hanford Site Radiological Control Manual, HSRCM-1, Rev. 2, HSRCM Project, U.S. Department of Energy, Richland, Washington.

Ecology, 1992, Washington State Department of Ecology Toxics Cleanup Program - Statistical Guidance for Ecology Site Managers, Washington State Department of Ecology, Olympia, Washington.

EPA, 1987, Statistical Methods for Evaluating the Attainment of Superfund Cleanup Standards, Volume 1: Scils and Solid Media, U.S. Environmental Protection Agency, Washington, D.C.

EPA, 1989, Methods for Evaluating the Attainment of Cleanup Standards, Volume 1: Soils and Solid Media, U.S. Environmental Protection Agency, Washington, D.C.

EPA, 1990, Field Measurements: Dependable Data When You Need It, EPA/530/UST-90/003, U.S. Environmental Protection Agency, Office of Underground Storage Tanks, September 1990.

EPA, 1994, Requirements for Quality Assurance Project Plans for Environmental Data Operations, U.S. Environmental Protection Agency, Washington, D.C.

EPA, 1996, Record of Decision for the U.S. Department of Energy Hanford 300-FF-1 and 300-F-5 Operable Units, U.S. Environmental Protection Agency, Region X, Richland, Washington.

McCain, R. G., 1993, "Qualitative Evaluation of Heavy Metals in Soils Using Portable XRF Instruments," WHC-SA-2162-FP, Westinghouse Hanford Company, Richland, Washington.

Teel, S. S. and K. B. Olsen, 1990, Final Report: Surface Radiation Survey for the Phase I Remedial Investigation of the 300-FF-1 Operable Unit on the Hanford Site, EMO-1008, Pacific Northwest Laboratory, Richland, Washington.

WHC, 1990, Strategy for Handling and Disposing of Purgewater on the Hanford Project, WHC-MR-0039, Rev. 0, Westinghouse Hanford Company, Richland, Washington.

WHC, 1993a, Data Validation Procedure for Radiochemistry Analyses, WHC-SD-EN-SPP-001, Rev. 1, Westinghouse Hanford Company, Richland, Washington. 
DOE/RL-96-70

Rev. 0

WHC, 1993b, Data Validation Procedures for Chemical Analyses, WHC-SD-EN-SPP-002, Rev. 2, Westinghouse Hanford Company, Richland, Washington.

Young, J. S., R. S. Fruland, and J. S. Fruchter, 1990, Data Compilation Task Report for the Source Investigation of the 300-FF-1 Operable Unit Phase I Remedial Investigation, PNL-7241, Pacific Northwest Laboratory, Richland, Washington. 
DOE/RL-96-70

Rev. 0

C- 62 
DOE/RL-96-70

Rev. 0

ATTACHMENT 1

SAMPLE LOCATION COORDINATES 
DOE/RL-96-70

Rev. 0 
DOE/RL-96-70

Rev. 0

\section{ATTACHMENT 1}

\section{SAMPLE LOCATION COORDINATES}

Description

Process Trench Spoils Area

Above Cleanup Levels

6 Randomly Located

Surface Samples
Easting

594,068

594,012

594,028

594,076

594,025

594,044

Process Trench Spoils Area

Undetermined Contamination Level

6 Test Pits

594,088

594,088

594,088

594,070

594,070

594,070

Process Trenches

Samples Beneath Concrete Aprons

2 Surface Samples

594,079

594,094

116,454

116,459
116,880

116,879

116,910

116,930

116,874

116,913
116,918

116,882

116,836

116,857

116,840

116,816

North Process Pond

Above Cleanup Levels

6 Randomly Located

594,195

116,582

Surface Samples

594,180

116,575

116,605

116,489

594,201

116,619

594,185

116,629 
DOE/RL-96-70

Rev. 0

Description

Easting

Northing

North Process Pond

Scrapings Disposal Area

8 Test Pits

$\begin{array}{ll}594,161 & 116,436 \\ 594,167 & 116,388 \\ 594,205 & 116,412 \\ 594,212 & 116,445 \\ 594,249 & 116,450 \\ 594,261 & 116,406 \\ 594,291 & 116,436 \\ 594,284 & 116,478\end{array}$

North Process Pond

Below Cleanup Levels

6 Randomly Located

594,233

116,587

Surface Samples

594,258

116,561

594,289

116,582

594,343

116,517

594,250

116,511

594,226

116,541

South Process Pond

Above Cleanup Levels

10 Randomly Located

594,203

116,066

Surface Samples

594,203

116,132

594,235

116,109

594,218

116,142

594,219

116,175

594,190

116,152

594,179

116,155

594,206

116,102

594,220

116,087

594,214

116,111 
DOE/RL-96-70

Rev. 0

Description

Easting

Northing

South Process Pond

Below Cleanup Levels

19 Randomly Located

594,266

116,077

Surface Samples

594,303

116,116

594,288

116,186

594,251

116,133

594,264

116,021

594,213

116,033

594,299

116,156

594,330

116,075

594,326

116,081

594,371

116,044

594,424

116,025

594,260

116,076

594,243

116,057

594,242

116,031

594,315

116,162

594,290

116,173

594,235

116,027

594,416

116,145

594,286

116,133

Ash Pits

Below Cleanup Levels

6 Randomly Located

594,281

115,978

Test Pits

594,315

115,936

594,359

115,947

594,366

115,989

594,284

115,946

594,250

115,973

Soil Stockpile Area South of Ash Pits and Active Filter Backwash Pond

6 Randomly Located

594,450

115,940

Test Pits

594,434

115,924

594,414

115,884

594,392

115,915

594,365

115,901

594,322

115,905

C-67 
DOE/RL-96-70

Rev. 0 
DOE/RL-96-70

Rev. 0

APPENDIX D

300 AREA ENVIRONMENTAL MANAGEMENT PUBLIC INVOLVEMENT PLAN

D-1 
DOE/RL-96-70

Rev. 0

D-2 
DOE/RL-96-70

Rev. 0

\section{APPENDIX D}

\section{AREA ENVIRONMENTAL MANAGEMENT PUBLIC INVOLVEMENT PLAN}

\subsection{OVERVIEW}

This plan outlines public involvement activities that will be conducted for the 300-FF-1 Operable Unit and the 300 Area Process Trenches remedial design and remedial action. The remedial alternatives described in the Record of Decision are selective excavation and disposal for the process waste sites and excavation and removal for the 618-4 Burial Ground.

\subsection{PUBLIC INVOLVEMENT PLANNING}

This public involvement plan outlines the strategy to be used to provide information during the remedial design and the remedial action processes. Throughout the public involvement process, decision making is the responsibility of all three agencies -- the U.S. Department of Energy, Richland Operations Office (DOE), Washington State Department of Ecology (Ecology), and U.S. Environmental Protection Agency (EPA).

\subsection{ACTIONS TO BE TAKEN DURING REMEDIAL DESIGN}

- Update the Hanford Advisory Board's Environmental Restoration Committee on project progress; the Committee will provide this information to the full Board. (Presentations to be scheduled)

- $\quad$ Provide government-to-government consultation with the Native American Tribes during remedial design, periodically during remedial actions, and/or when pertinent information becomes available. DOE will transmit documents to the Tribes at the same time they are transmitted to Ecology and EPA.

- Presentation to Natural Resource Trustee Council on the 300-FF-1 design and mitigation action plan. Presentations were held on May 9, 1996 at 30\% design and June 12, 1996 at $60 \%$ design. (Additional presentations may be scheduled)

- $\quad$ Provide information for the general public. (Hanford Update articles, Hanford Reach articles, and media releases - as new information becomes available)

- $\quad$ Prepare a fact sheet to describe 300-FF-1 and the 300 Area Process Trenches Modified Closure/Postclosure Plans. (A new fact sheet will be prepared if required) 
DOE/RL-96-70

Rev. 0

\subsection{ACTIONS TO BE TAKEN DURING REMEDIAL ACTION}

Actions will be taken to provide information to interested stakeholders as pertinent information becomes available.

- Update the Hanford Advisory Board's Environmental Restoration Committee on project progress; the Committee will provide this information to the full Board. (As needed or requested)

- Provide government-to-government consultation with the Native American Tribes. (As needed or requested)

- Presentation to Natural Resource Trustee Council. (As needed or requested)

- $\quad$ Provide information for the general public. (Hanford Update articles, Hanford Reach articles, and media releases - as new information becomes available)

- Prepare videotapes and collect photographs showing progress of project.

\subsection{ACTIONS TO BE TAKEN FOR SIGNIFICANT CHANGES TO THE SELECTED REMEDY}

It may be determined that a significant change to the selected remedy, as described in the record of decision, is necessary. Significant changes are defined as changes that significantly modify the scope, performance, or cost of a component of the remedy as presented in the record of decision. All significant changes shall be addressed in an explanation of significant difference.

- Update the Hanford Advisory Board's Environmental Restoration Committee on the change; the Committee will provide this information to the full Board.

- Provide government-to-government consultation with the Native American Tribes on the change.

- Presentation to Natural Resource Trustees on system and mitigation plan if change affects mitigation plan.

- Prepare a fact sheet to describe the change; send to mailing list.

- Conduct formal public comments, if required.

- Information for the general public. (Hanford Update articles, Hanford Reach articles; press releases) 
DOE/RL-96-70

Rev. 0

\section{DISTRIBUTION}

ONSITE

66 copies

U.S. Department of Energy.

Richland Operations Office

R. G. McLeod (17)

H0-12

Public Reading Room

H2-53

ERC Team

M. D. Baker

H9-12

R. A. Carlson (25)

L6-06

R. S. Claeson

$\mathrm{H} 0-17$

J. W. Darby

$\mathrm{H} 0-18$

S. O. DeLeon

H9-12

S. K. DeMers

$\mathrm{X} 0-23$

V. R. Dronen

H0-09

J. H. Dunkirk

$\mathrm{H} 0-13$

D. A. Duranceau

$\mathrm{X} 0-17$

S. C. Foelber

H0-09

F. W. Gustafson

H9-11

C. R. Johnson

L6-06

W. M. Lambert

$\mathrm{X} 3-40$

R. I. Orewiler

L6-06

D. D. Teel

$\mathrm{H} 0-02$

W. S. Thompson

$\mathrm{N} 1-28$

B. G. Tuttle

$\mathrm{X} 0-34$

R. H. Wyer

H0-09

Document Information Services (4)

H0-09

Pacific Northwest National Laboratory

M. H. Schlender

K9-18

PNNL Technical Library

P8-55

Distr-1 